\title{
A Survey of the Piano Sonatas of Wilhelm Stenhammar (1871-1927) with Performance Suggestions for the Piano Sonata in $\mathrm{G}$ Minor
}

Maria Crystalia

West Virginia University

Follow this and additional works at: https://researchrepository.wvu.edu/etd

\section{Recommended Citation}

Crystalia, Maria, "A Survey of the Piano Sonatas of Wilhelm Stenhammar (1871-1927) with Performance Suggestions for the Piano Sonata in G Minor" (2014). Graduate Theses, Dissertations, and Problem Reports. 437.

https://researchrepository.wvu.edu/etd/437

This Dissertation is protected by copyright and/or related rights. It has been brought to you by the The Research Repository @ WVU with permission from the rights-holder(s). You are free to use this Dissertation in any way that is permitted by the copyright and related rights legislation that applies to your use. For other uses you must obtain permission from the rights-holder(s) directly, unless additional rights are indicated by a Creative Commons license in the record and/ or on the work itself. This Dissertation has been accepted for inclusion in WVU Graduate Theses, Dissertations, and Problem Reports collection by an authorized administrator of The Research Repository @ WVU.

For more information, please contact researchrepository@mail.wvu.edu. 


\title{
A Survey of the Piano Sonatas of Wilhelm Stenhammar (1871-1927) with Performance Suggestions for the Piano Sonata in G Minor
}

\author{
Maria Crystalia \\ A Doctoral Research Project Submitted to \\ The College of Creative Arts \\ at \\ West Virginia University \\ in partial fulfillment of the requirements for the degree of \\ Doctor of Musical Arts \\ in \\ Piano Performance \\ James Miltenberger, D.M.A. Chair and Research Advisor \\ Lucy Mauro, D.M.A. \\ William Haller, D.M.A. \\ Keith Jackson, D.M.A. \\ Charles Jaffe, Ph.D.
}

\section{West Virginia University \\ College of Creative Arts \\ School of Music \\ Morgantown, West Virginia \\ 2014}

Keywords: Stenhammar, Swedish piano composer, Scandinavian composer 


\begin{abstract}
A Survey of the Piano Sonatas of Wilhelm Stenhammar (1871-1927) with Performance Suggestions for the Piano Sonata in G Minor
\end{abstract}

\title{
Maria Crystalia
}

This research project is a brief analysis of the formal structures of five sonatas and performance suggestions for the G minor piano sonata of Wilhelm Stenhammar. This paper explores aspects of piano performance, such as the basic technical approach, interpretation suggestions, as well as examinations of pedaling, possible fingering, dynamics, and articulation. Selected aspects of texture, harmony, melody, rhythm, and form are discussed as they relate to the interpretation and performance of the $\mathrm{G}$ minor sonata. This paper also provides an approximate assessment of level of difficulty and serves as a guide for teachers, students, and musicians who are interested in the discovery and presentation of piano works which are not included in the traditional concert repertoire. 


\section{TABLE OF CONTENTS}

CHAPTER I: Introduction $\quad 1$

- Purpose of the Study $\quad 1$

- Need for the Study $\quad 2$

- Limitations of the Research $\quad 3$

- Research Design $\quad 3$

CHAPTER II: Review of Existing Literature $\quad 4$

- Books $\quad 5$

- Articles, Journals, and Online Databases 9

- Dissertations $\quad 10$

CHAPTER III: Biographical Information $\quad 12$

CHAPTER IV: Survey of the Piano Sonatas 16

1. A brief analysis of the early sonata in C Major $\quad \mathbf{1 6}$

2. A brief analysis of the early sonata in $\mathrm{C}$ minor $\quad \mathbf{2 2}$

3. A brief analysis of the early sonata in A-flat Major $\quad 27$

4. A brief analysis of mature piano work in G minor 35

5. A brief analysis of mature piano work in A-flat Major, Op. $12 \quad 47$

CHAPTER V: Performance Suggestions for the Piano Sonata in G minor 6

CHAPTER VI: Conclusion $\quad 74$

- Summary $\quad 74$

- Suggestions for future research $\quad \mathbf{8 0}$

$\begin{array}{lr}\text { Bibliography } & 81\end{array}$

$\begin{array}{lc}\text { Appendix } & \mathbf{8 3}\end{array}$ 


\section{CHAPTER I: Introduction}

\section{Purpose of the Study}

In this research paper, I discuss the five piano sonatas of the Swedish classic- romantic composer Wilhelm Stenhammar. Despite being one of the finest concert pianists of his era, he did not write many works for piano. His piano repertoire includes five piano sonatas, character pieces (Three Fantasies, Op. 11 and Sensommarnätter, Op. 33) and two piano concerti (Op. 1 and Op. 23). Most of these works come from early in his career. Later he increasingly devoted himself to the composition of other genres. He also became more interested in conducting in the latter part of his life. His piano sonatas were written between 1880-1895 and are all multimovement sonatas.

This paper provides biographical information on Stenhammar, insight into his compositional style, and performance suggestions for the G minor Sonata. This will include a discussion of the basic technical approach needed, an examination of pedaling, fingering, dynamics, and articulation. Selected aspects of texture, harmony, melody, rhythm, and form will be discussed as they relate to the interpretation and performance of these pieces.

The selected repertoire is:

Piano Sonata in C Major (1880)

I. Allegro Moderato (5'29)

II. Andante (2'06)

III. Menuetto (1'44)

IV. Rondo (1'13)

Piano Sonata in C minor (1881)

I. Allegro (6'12)

II. Andante (3'48)

III. Finale (3'19)

Piano Sonata in A flat major (1885)

I. Allegro (7'21)

II. Adagio grazioso (6'02)
Obtained copy from

Swedish Music

Library

Obtained copy from

Swedish Music

Library

Obtained copy from

Swedish Music

Library 
III. Presto marcato 1'00

IV. Finale: Rondo (5'10)

Piano Sonata in G minor (1890)

Published in 2008

I. Allegro vivace e passionato (9'03)

II. Romanza (4'46)

III. Scherzo (2'42)

IV. Rondo (5'42)

Piano Sonata in A-flat Major, Op. 12 (1895)

I. Moderato, quasi andante

II. Molto Vivace- Trio: Presto- Tempo 1- Coda:Presto

III. Lento e mesto- Allegro

Published during his

life in $1895^{1}$

These sonatas represent various styles ranging from the style of classical composers such as Mozart, Haydn, and Beethoven to romantic composers such as Schumann, Liszt, and Chopin. Generally, Stenhammar's piano sonatas are written in a traditional Germanic multiple movement sonata structure. He begins to utilize his own harmonic language in his last two piano sonatas in g minor and A-flat Major, Op.12.

\section{Need for the Study}

A review of literature related to the selected repertoire shows that many sources consist of biographical studies of the composer, a brief analysis of form, and a listing of available recordings. However, very few studies and recordings were found that focused on his early sonatas in $\mathrm{C}$ Major, $\mathrm{C}$ minor and A-flat Major. To complement the existing research, there is a need for studies related to these early piano compositions. Such studies will lead to a better understanding of the evolving style of the Stenhammar sonatas.

\footnotetext{
${ }^{1}$ Martin Sturfält. "Stenhammar,Wilhelm” In Musikaliskakonstforeningen.se Online, http://www.musikaliskakonstforeningen.se/Verkinfo_eng/Stenhammat\%20pianoworks.html (accessed on September $10,2013)$
} 


\section{Limitation of the Research}

This study is limited to a brief analysis of the five piano sonatas and performance suggestions for the $\mathrm{G}$ minor sonata. It guides the student to understand, to interpret, and to become familiar with these sonatas. This paper is not intended to be an in-depth historical or theoretical study of the five piano sonatas.

\section{Research Design and Analysis}

This research paper consists of six chapters. In Chapter I, there is an introduction to this study. In Chapter II, there is a review of available resources including scholarly books, dissertations and journal articles related to the composer's biography. In Chapter III, there is a discussion of Stenhammars's biographical information and general background. In Chapter IV, there is a brief analysis of the five piano sonatas. In Chapter V, there is a discussion on the performance suggestions for the $\mathrm{G}$ minor sonata. In the Final chapter, I present a conclusion that consists of a summary and recommendations for future research.

\section{Research Methodology and Scope}

The research project includes as many resources as possible up to the most recent. Readers may find resources that discuss the composer's biography, his early compositional style, and performance practice. Resources include books, journals/ articles, dissertations, and recordings of the works. All included resources are written in English -- some are originally in Swedish but include an English translation. The sources were found by exploring different search engines such as: RILM Abstracts of Musical Literature; ProQuest Dissertations and Thesis; JSTOR; WorldCat (First Search); EBSCOhost (Ebooks); Grove Music Online; Naxos Music Library; and West Virginia MountainLynx catalog. In total, four books, five articles, six recordings, and two dissertations were accessed for this project. 


\section{CHAPTER II: Review of Existing Literature}

Musicologists have conducted numerous studies of Scandinavian music in the last few decades. These share the common efforts: to renew interest in Scandinavian music, to increase awareness of lesser-known composers, and to discover and to appreciate the music of these composers. For this research project, a search of databases such as RILM, ${ }^{2}$ WorldCat, ${ }^{3}$ JSTOR, ${ }^{4}$ and ProQuest Dissertation and Theses ${ }^{5}$ shows a number of books, journals, and dissertations in English and/or in translation that are relevant.

With a limited number of resources in English, it is a challenge to find information about Stenhammar's early piano sonatas. Furthermore, there is confusion about the numbering of the piano sonatas. Due to the lack of knowledge about the existence of the earlier sonatas, some scholars have labeled the sonata in A-flat Major, Op. 12 (1895) as Sonata no. 3. In fact, chronologically, there is an earlier piano sonata without opus number that was written in 1885 and shared the key of A-flat Major. Consequently, there is an inconsistency in numbering the piano sonatas and it varies from one book/source to another.

Since the research efforts of this paper focus on performance suggestions for G minor piano sonata, I will concentrate on selected literature containing the composer's biographical information and those sources which discuss the piano sonatas. This research project is intended to provide a brief overview of Stenhammar and his piano sonatas and to serve as a scholarly resource for further studies. It begins with a review of the books that relate to the piano sonatas then follows by a review of Articles, Journals, Online Databases and Dissertations.

\footnotetext{
${ }^{2}$ RILM Abstracts of Music Literature: RILM Abstracts of Music Literature is a comprehensive music bibliography featuring citations, abstracts, and indexes.

${ }^{3}$ WorldCat.org: find books located in libraries around the world and use links to WVU library content and services for easy access.

${ }^{4}$ JSTOR: JSTOR is a digital library of academic journals, books, and primary sources.

${ }^{5}$ ProQuest Dissertation and Theses databases: ProQuest is the official and the world's most comprehensive collection of dissertations and theses archives for research.
} 


\section{Books}

Bo Wallner was a Swedish musicologist who taught at the Stockholm Conservatory. According to John Bergsagel, "His passion towards Scandinavian music made him as one of the most astute observers. ${ }^{\circ 6} \mathrm{He}$ wrote many articles and textbooks relating to Scandinavian music. Relevant to this study is a brief monograph on Wilhelm Stenhammar, published in English in 1972 by the Swedish Music Information Center. This monograph includes a resume of the composer's life and a discussion of selective repertoire compiled by Per Olof Lundahl.

The material is organized chronologically. Important events in the composer's life are cited followed by a discussion of the repertoire from that period. This provides general information to musicians who are interested in Stenhammar's works and serves as a guideline fostering scholarly research. Since this is a brief monograph, it does not provide information concerning the smaller pieces.

In 1991, Mr. Wallner decided to expand this monograph to a comprehensive threevolume set of books (Wilhelm Stenhammar och hans tid. Vol1-3). This monumental publication includes approximately 1900 pages and examines Stenhammar's music in detail. ${ }^{7}$ To date, this massive 3-volume publication can only be found in Swedish and has not yet been translated into English. This is an obstacle for English-readers. However, I have found an article which gives more information about this 3-volume work. A review article by John Weinstock's states, "Wallner includes not only a biography but a cultural history of Sweden during the forty-odd years around the turn of the century and as such will be of interest not only to music specialist

\footnotetext{
${ }^{6}$ John Bergsagel and Henrik Karlsson, "Wallner, Bo." In Grove Music Online. Oxford Music Online. http://www.oxfordmusiconline.com/subscriber/article/grove/music/29851 (accessed January 16, 2013). ${ }^{7}$ John Weintstock, Wilhelm Stenhammar och hans tid. Vol. 1: Vol. 2: Vol. 3 by Bo Wallner, Scandinavian studies 65, no.1 [Winter 1993]: 148-152. 
but to anyone dealing with Swedish literature, art, architecture, and culture." ${ }^{\prime 8}$ An extensive discussion of most of Stenhammar's compositions is included. Weinstock believes that this 3volume collection is a must for any serious library or for individuals interested in Swedish cultural and musical history.

Robert Quist's The History of Modern Swedish Music: An Introduction to Nineteen Composers (published in 2010) examines Swedish Art music during modern times. Mr. Quist dedicates a chapter for each composer. He examines nineteen composers who wrote in a variety of styles: the late romantic, the Nationalist, the Modernist, the neo-classicist, and the modern avant-garde. Each chapter outlines the composers' lives and works. Stenhammar can be found in chapter one. Quist believes that Stenhammar's role in Swedish music went beyond classicism. Stenhmammar exerted a strong influence on modern Swedish composers including Rosenberg, who modeled his own style on Stenhammar's works. Rosenberg was the composition teacher for a majority of the notable Swedish modernists. ${ }^{9}$

Mr.Quist said, "Stenhammar represents the closest Swedish figure of international status comparable to Grieg and Sibelius. Yet, Stenhammar never became quite the giant that these other two composers became. In an odd way, his more modest reputation seemed less intimidating to later generations of Swedish composers. ${ }^{, 10}$ Quist also discusses Stenhammar's musical styles "Stenhammar masters multiple styles. When he was around ten years old, he composed three piano sonatas that seem almost interchangeable with Beethoven, Schubert, and Mozart's piano works. Later, in his early twenties, he found his own individual voice as well as learning the style of Schumann, Chopin, Grieg, Mendelssohn, and especially Wagner. Stenhammar's unique tonal

\footnotetext{
${ }^{8}$ Weintstock, Wilhelm Stenhammar och hans tid. Vol. 1: Vol. 2: Vol. 3 by Bo Wallner, Scandinavian studies 65, no.1 [Winter 1993]: 148.

${ }^{9}$ Robert Quist, The History of Modern Swedish Music: An Introduction to Nineteenth Composers [New York: The Edwin Mellen Press, 2010], 8.

${ }^{10}$ Ibid, 8.
} 
style moved in a reverse direction from the European trend. As Wagner, Liszt, and Mahler developed more complex chromatic works, Stenhammar began with Wagnerian chromaticism and moved more toward a simple and subtle harmonic language."11

The Scandinavian Music: A Short History by John Horton is a survey of music history from the pre-Christian and medieval period through the twentieth century. The author presents the musical developments in Denmark, Norway, Finland, and Sweden. This book consists of fourteen chapters, which are chronologically arranged according to the period and musical style. Numerous illustration and musical examples are included. Horton devoted the last chapter to Swedish composers- Stenhammar and Modern Swedish Music. The author states that Stenhammar belongs to "the age of realism in Sweden." "This reflects his interest in modern Swedish poetry even though musically he remained in the spirit of romanticism. ${ }^{13}$ The author believes that Stenhammar's finest period as a composer dates from about $1910 .{ }^{14}$ As a result, no mention is made of his early works including the piano sonatas.

Maurice Hinson's Guide to the Pianist's Repertoire (published 1973,1987, 2001, and in progress for $4^{\text {th }}$ edition -2013) has been extensively revised and continuously used as an essential guide for teacher, students, and performers. This book includes biographical sketches of major composers. Mr. Hinson offers a brief description, music score publication, approximate performance time and level of difficulty, and style and characteristics. According to Hinson, "Stenhmmar began as a national romantic in the neoromantic vein but gradually achieved simplicity, refinement and concentration in his musical language. ${ }^{15}$ In the second edition,

\footnotetext{
${ }^{11}$ Quist, The History of Modern Swedish Music: An Introduction to Nineteenth Composers [New York: The Edwin Mellen Press, 2010], 17.

${ }^{12}$ John Horton, Scandinavian Music: A Short History [London: Faber and Faber, 1963], 155.

${ }^{13}$ Ibid., 155.

${ }^{14}$ Ibid., 154.

${ }^{15}$ Maurice Hinson and Irwin Freundlich, Ed. Guide to the Pianist's Repertoire [Bloomington: Indiana University Press, 1973], 619.
} 
Hinson included Stenhammar's piano sonata in G minor, in A-flat Major Op.12 and other character pieces. However, in the third edition, piano sonata in $\mathrm{G}$ minor has been excluded (perhaps because it was not published until recently). Hinson only labels Stenhammar's sonatas by the key (not by number).

David Dubal's The Art of the Piano: Its Performers, Literature, and Recording (published in 1995) surveyed and compiled recordings catalog of essential piano works that are available up to date. Mr. Dubal is aware of recording by Lucia Negro, who is a longtime advocate of Stenhammar and has recorded the solo music including all of his sonatas. According to Dubal, "The Romanza (second movement) from the $1890 \mathrm{G}$ minor piano sonata has popular quality. Perhaps more interesting is the Sonata No.2 in A-Flat, Op. 13 (1895)", ${ }^{, 16}$. However, a typo is found on the opus number of sonata in A-flat and there is a question about the sonata number. Perhaps, Mr. Dubal thinks the first three sonatas are more sonatina-like so that only G minor and A-flat, Op. 12 could be considered as the sonatas of Stenhammar.

All Music Guide to Classical Music: the Definitive Guide to Classical Music (published 2005) by Chris Woodstra, Gerald Brennan, and Allen Schrott is another essential review of recordings in a one-volume book. Like the Dubal, this book compiles and contains over 500 composers and 800 performer biographies including coverage of not only solo works, but also other musical genres such as choral works, opera(s), symphonies, and concerti. This book is arranged alphabetically by the last name of the composers. A brief discussion of the composer's life and review of recordings are provided by music guide editor Steven Coburn. He recommended the recording of Wilhelm Stenhammar: The Complete Solo piano Music Vol.1-3 by Lucio Negro. Coburn also categorized Stenhammar's musical styles evolving through three

\footnotetext{
${ }^{16}$ David Dubal, The Art of the Piano: Its Performance, Literature, and Recordings [New Jersey: Amadeus Press, 2004], 678.
} 
periods: (1) Early period which was influenced by Liszt, Brahms, and Wagner, but the music is imbued with a Nordic sound without specifically quoting Swedish folksong; (2) Middle period which began as he attempted to create more concentrated and motivically oriented style, modeled on the great classicists Beethoven, Haydn, and Mozart. In spite of this, the music of this period loses none of its Nordic color. The Piano Concerto No.2 is the most representative; (3) The last period, where the music becomes more contrapuntally and modally oriented. ${ }^{17}$

\section{Article, Journal, and Online Database}

The Grove Music Online and The Oxford Companion to Music Online are among the most helpful online resources to discuss Stenhammar's biographical information, compositional style, and a general overview of his works. These include several articles from: (1) Bo Wallner and Hans Åstrand-“Stenhammar, Wilhelm” from The Grove Music Online ${ }^{18}$ and; (2) Stephen Johnson - "Stenhammar, (Karl) Wilhelm (Eugen)" from The Oxford Companion to Music Online. ${ }^{19}$ Despite being one of informative resources, these articles do not provide any information in regard to his piano sonatas.

Edward Rothstein's article Piano: Works of Nordics (1981) is a performance review of Michael Rogers who played "Great music from Scandinavia" in Alice Tully Recital Hall on Wednesday, October $14^{\text {th }}, 1981$. The program included the works of Stenhammar (Piano Sonata in G minor and Sensommarnätter, Op. 33), Grieg (Three Norwegian Folk Songs, Op. 66), and Nielsen (Suite for Piano). Mr Rothstein stated, "Stenhammar's Sonata in G minor (1890) was replete with Brahmsian gesture and passion, but it gave the impression of an outsider viewing

\footnotetext{
${ }^{17}$ Steven Coburn, Chris Woodstra, Gerald Brennan, and Allen Schrott, All Music Guide to Classical Music: The Definitive Guide to Classical Music [San Francisco, CA: Backbeat Books, 2005], 1305-06.

${ }^{18}$ Bo Wallner and Hans Åstrand, "Stenhammar, Wilhelm." In Grove Music Online. Oxford Music Online, http://www.oxfordmusiconline.com/subscriber/article/grove/music/26677 (accessed October 21, 2013).

${ }^{19}$ Stephen Johnson. "Stenhammar, (Karl) Wilhelm (Eugen)." In The Oxford Companion to Music.Oxford Music Online, http://www.oxfordmusiconline.com/subscriber/article/opr/t114/e6447 (accessed October 21, 2013).
} 
that middle-European world from a distance. The piano was often used with widely separated registers, suggesting a spare, spacious realm. The echoes of Liszt, Wagner, Schumann, Chopin and Brahms evoked a solitary melancholy, not warm desire, dreaminess, elegance or nostalgia."20

\section{Dissertation}

Johan Frost's doctoral dissertation, Swedish Piano Music by Stenhammar in the Shadow of Grieg (2001), is one of the few resources that discuss the composer's life, musical career, and works. Mr. Frost dedicated Chapter 2 to Stenhammar's life and Stenhammar as a composer of piano music. He includes not only biographical information, but also discusses the evolvement of styles seen in Stenhammar's piano sonatas and his other piano music. According to Frost, the first three youthful piano sonatas show a great deal of classical influence from Mozart, Schubert, and Beethoven though sometime indicate signs of harmonic originality. ${ }^{21}$ Frost provides an examination of basic features of the piano sonata in $\mathrm{G}$ minor. He includes examples of themes from each movement, harmonic and melodic discussion, and an outline of the form. Frost believes that this $\mathrm{G}$ minor sonata is reminiscent of Schumann. ${ }^{22}$

Armen Shaomian's dissertation, The Influence of composers Wilhelm Petersen-Berger and Wilhelm Stemhammar on Swedish National Romaticim (2008), is hope to introduce the music of the National Romantic period in Swedish Cultural history to a wider audience. He includes a discussion of the folk influence on music, art, and architecture throughout the late

\footnotetext{
${ }^{20}$ Edward Rothstine, "Piano works of Nordics." In New York Times Press, http:/www.nytimes.com/1981/10/16/arts/piano-works-of-nordics.html (Accessed November 15th, 2013)

${ }^{21}$ Johan Frost, " Swedish Piano Music by Stenhammar in the Shadow of Grieg” [D.M.A diss., Rice University, 2001], 32 .

${ }^{22}$ Ibid., 54.
} 
1800s until the early1900s. ${ }^{23}$ Shaomian selects two important Swedish composers as representative of the period: Willhelm Petersen-Berger and Wilhelm Stenhammar. He includes a brief background about each composer and illustrates how Swedish folk elements are present in their works. While a helpful point of reference, this dissertation does not provide information about Stenhammar's piano sonatas.

${ }^{23}$ Armen Shaomian, "The Influence of Composers Wilhelm Peterson-Berger and Wilhelm Stenhammar on Swedish National Romanticism.”[D.M.A diss., Univeristy of Miami, 2008] 


\section{CHAPTER III: Biographical Information}

Wilhelm Stenhmmar was born in Stockholm on February 7, 1871, and died in Stockholm on November 20, 1927. His father Per-Ulrik Stenhammar was an architect and an established church composer, and his mother Louise Rudenschiöld was a draughtswoman. ${ }^{24}$ Wilhelm grew up in a respected cultural, religious and musical family in Stockholm. That the young Stenhammar inherited the musical talent from his father was recognizable at an early age. Yet, it was only after his father's death in 1875 that Stenhammar's musical talent was exposed since his father did not approve his attempt to try out his musical ambitions. ${ }^{25}$ He showed ability to compose and to play the piano at an early age even without much formal training. With a minimum compositional training, a young Stenhammar could be regarded as self-taught. His childhood composition includes the little known three piano sonatas: C Major (1880), C minor (1881), and A-flat Major (1885). These sonatas are in the style of August Söderman ${ }^{26}$ (18321876) as well as other classic composers like Mozart and Schubert. ${ }^{27}$

Stenhammar received his first formal training at the age of sixteen in 1887 . He began his piano studies with the prominent Swedish teacher Richard Andersson, who was a student of Clara Schumann. Andersson introduced the young Stenhammar to the works of the Classic (Mozart and Beethoven) and Romantic (Chopin, and Schumann) composers. Andersson also transformed the young Stenhammar into a virtuoso pianist. Stenhammar became familiar with European art music which inspired him to write in that style. He studied composition with Emil

\footnotetext{
${ }^{24}$ Bo Wallner, Wilhelm Stenhammar [Stockholm: Swedish Music Information Center, 1972], 3

${ }^{25}$ Frost, "Swedish Piano Music by Stenhammar in the Shadow of Grieg" [D.M.A diss., Rice University, 2001 ], 32.

${ }^{26}$ Söderman was a Swedish composer. His works occupy a position of central importance in Swedish music, and exerted a great influence on later generations of Swedish composers.

Kathleen Dale and Axel Helmer, “August Söderman” In Grove Music Online. Oxford Music Online, http://www.oxfordmusiconline.com/subscriber/article/grove/music/26088?q=August $+\mathrm{S} \% \mathrm{C} 3 \% \mathrm{~B} 6 \mathrm{derman}+\& \mathrm{search}=$ quick\&pos $=1 \&$ start=1\#firsthit (accessed March 25, 2014).

${ }^{27}$ Frost, Swedish Piano Music by Stenhammar in the Shadow of Grieg, 31.
} 
Sjögren and Andreas Hallén ${ }^{28}$ (1888-1892). He composed a variety of musical genres such as the Tre körvisor $(1890)^{29}$ for choir, Drei Lieder, Op. 17 (1888-1890) for voice and piano, sonata in G minor for solo piano (1890), and many other works. Stenhammar also completed his organist examination privately in 1890 after studying two years with Wilhelm Heintze. ${ }^{30}$ Stenhammar developed his pianistic skills and became a virtuoso pianist. His repertoire included a large number of Mozart's works, Beethoven's sonatas, and accompaniments and chamber music. ${ }^{31}$ His foremost public recognition occurred in 1892. He gave a successful performance of Brahms's D minor piano concerto in Stockholm, and collaborated with the nationally famous Aulin Quartet. ${ }^{32}$ Despite his successful musical career as a pianist, he continued to pursue further piano study in Berlin with Heinrich Barth (1892-93) and also devoted himself increasingly to conducting and composing. He completed his first piano concerto in Bflat minor, Op. 1, and gave the premier performance in 1894. This concerto was later played at a series of concerts in Scandinavia, then later in Berlin under the baton of Richard Strauss, and in England under the baton of Hans Richter. ${ }^{33}$

His first piano concerto in B-flat Major, Op. 1 (1893), is probably the one of the most significant nineteenth century Scandinavian piano concerti, and it established the young Stenhammar's reputation as a composer. The success of the first piano concerto also prompted Stenhammar to compose the second piano concerto in D minor, Op. 23 (1904-1907). This composition marked his accomplishment as one of the significant late romantic Scandinavian composers after its initial success in 1907. This concerto became Sweden's most performed

\footnotetext{
${ }^{28}$ Andreas Hallén is Swedish Romantic composer, conductor, music teacher who is influenced by Richard Wagner.

${ }^{29}$ Bo Wallner and Hans Åstrand, "Stenhammar, Wilhelm." In Grove Music Online. Oxford Music Online, http://www.oxfordmusiconline.com/subscriber/article/grove/music/26677 (accessed January 1,2014).

${ }^{30}$ Dick Litell, trans., Swedish Music -Past and Present [Stockholm: Musikrevy, 1967], 79.

${ }^{31}$ Frost, Swedish Piano Music by Stenhammar in the Shadow of Grieg, 32.

${ }^{32}$ Litell, 79.

${ }^{33}$ Wallner, Wilhelm Stenhammar, 3.
} 
concerto. ${ }^{34}$ With his consecutive successful debut as a young talented pianist and composer, he eventually became one of the most important and influential Scandinavian musicians of his time.

As one of the finest Swedish pianists and composers at this time, one might expect that the piano will be the primary medium and will occupy the center position in his output. In fact, he wrote surprisingly few piano works and only few of them were published during his lifetime. He seemed reluctant to perform his own solo works. Perhaps, he was finding his solo works were too short and small-scale compared to his concerti. As a result, Stenhammar only performed his solo works once and never returned to these works. The three published piano works were Three Fantasies, Op. 11 (1895), Sonata in A-flat Major, Op. 12 (1895), and Sensommarnätter, Op. 33 (1900). The rest of his piano solo works were donated to the Music Library of Sweden after Stenhammar's death. This includes his piano sonata in G minor.

The manuscript of the G minor Piano Sonata was rediscovered and was recently published in 2008. His compositional style was of a late romanticist with roots in the music of Mozart, Beethoven, Chopin, and Schumann. Unlike other nationalist composers at his time, he made little use of folk elements in his music. In addition to the piano works, he continued composing in a variety of genres throughout his career. This included two symphonies, a violin sonata, six string quartets, opera and choral works including the small-scale Lieder and largescale works for chorus and orchestra, and cantatas. ${ }^{35}$

At the age of twenty-five, Stenhammar married the artist Helga Westerberg in 1896. The civil ceremony took place in Gothenburg. Their first-born son was born in 1897, a daughter in 1899, and another son in 1901. Stenhammar felt increasing financial pressure to meet the needs

\footnotetext{
34 Quist, The History of Modern Swedish Music: An Introduction to Nineteenth Composers [New York: The Edwin Mellen Press, 2010], 36.

${ }^{35}$ Bo Wallner and Hans Åstrand, "Stenhammar, Wilhelm.” In Grove Music Online. Oxford Music Online, http://www.oxfordmusiconline.com/subscriber/article/grove/music/26677 (accessed January 1,2014).
} 
of his fast-growing family. ${ }^{36}$ A self-taught conductor, he made his debut in 1897 and accepted a position with the orchestra in Stockholm the following year. He also conducted the 1900-01 season at the Royal Opera. The next appointment was as the Gothenburg Symphony conductor and artistic director in 1907. He remained very active as a conductor, a soloist with orchestras, and an ensemble pianist.

In 1922, Stenhammar's health declined and he decided to leave the post in Gothenburg and return to Stockholm. The following year, he became a music director at the Royal Opera of Stockholm. However, this appointment was not long lasting as his health continued to get worse after a stroke in 1925. He died after suffering from another stroke in 1927.

${ }^{36}$ Annette Johansson, Thirty Songs of Wilhelm Stenhammar: The Composer and His Romanser (New York: Leyerle Publications, 1999), 157. 


\section{CHAPTER IV: Survey of the Piano Sonatas}

The study includes a brief analysis of five piano sonatas in an order of:

- The early piano sonatas: (1) C Major; (2) C minor; (3) A-flat Major.

- Mature piano sonatas: (4) G minor; (5) A-flat Major, Op. 12.

\section{(1) Sonata in C Major}

This sonata was composed in May1880 and dedicated to Marie Louise Öberg, who was the piano teacher of the nine-year-old Stenhammar. ${ }^{37}$ Miss Öberg studied composition at the Stockholm Conservatory with Franz Berwald, who was a prominent Swedish romantic composer at the time. The sonata in C Major is in four-movements.

The first movement: Allegro Moderato

This movement is written in symmetrical binary-form and is in 4/4 meter. A brief analysis of the movement is presented in the table below:

\begin{tabular}{|l|l|l|l|l|l||}
\hline \multicolumn{2}{|l|}{ A section } & : & B section & & \\
\hline $\begin{array}{l}\text { Theme 1 } \\
\text { mm. 1- 16 }\end{array}$ & Theme 2 & Closing Theme & Theme 1 & Theme 2 & Closing theme \\
mm. 45-60 & mm. 37-44 & mm. 61-80 & mm. 81-88 \\
Key: CM & GM & GM & GM & CM & CM \\
I- v- I-v & V & & V --modulate & I & I \\
\hline
\end{tabular}

This movement has two main sections: A and B. Each section has 44 measures. They are similar and consist of the first theme, the second theme and the closing theme. The A section introduces the first theme in C Major and is in a homophonic texture (see example 4.1.1).

\footnotetext{
${ }^{37}$ Per Skans, liner notes to Wilhelm Stenhammar, The complete Solo Piano Music Volume 2, BIS Records CD-634, 1995.
} 
Example 4.1.1: Sonata in C Major "Allegro Moderato" ( $1^{\text {st }}$ movement): $1^{\text {st }}$ theme (mm. 1-4)

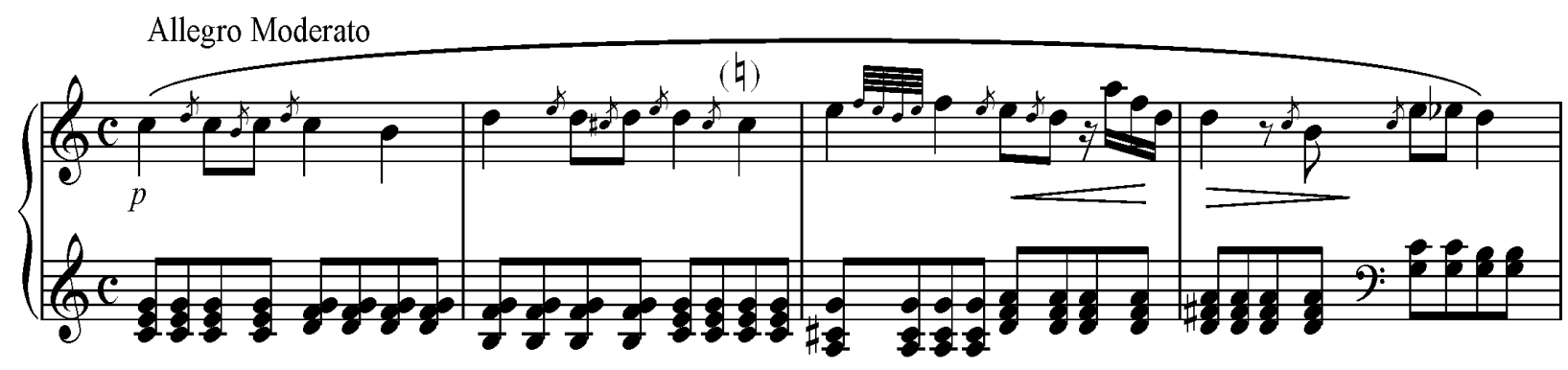

The natural sign in parentheses in measure 2 is added on the note $\mathrm{C}$. There is no natural sign in the manuscript. It will make more sense if the note $\mathrm{C}$ is $\mathrm{C}$-natural as it is accompanied by a C Major chord in the left hand.

The first theme harmony alternates between the tonic and the dominant in the opening measure. However, it also comes with a surprising modulation. Instead of C Major to the dominant key, it shifts to a $\mathrm{G}$ minor chord sequence (see example 4.1.2).

Example 4.1.2: Sonata in C Major "Allegro Moderato" ( $1^{\text {st }}$ movement): 1 theme (mm. 5-8).
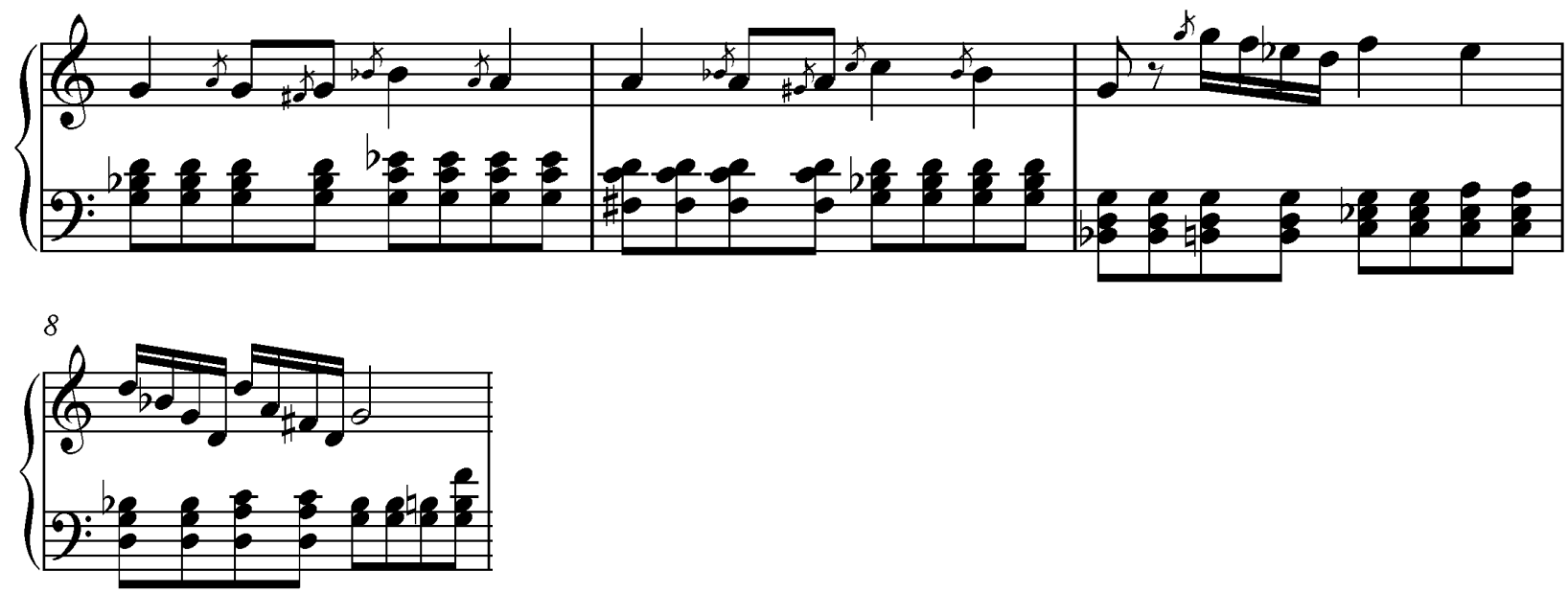

Following is the second theme in $\mathrm{m} .17$; it modulates to the dominant. The texture has changed to a four- part chordal texture (see example 4.1.3). This is a lyrical section as contrasted to the first theme. 
Example 4.1.3: Sonata in C Major "Allegro Moderato" $\left(1^{\text {st }}\right.$ movement): $2^{\text {nd }}$ theme (mm. 17-20).

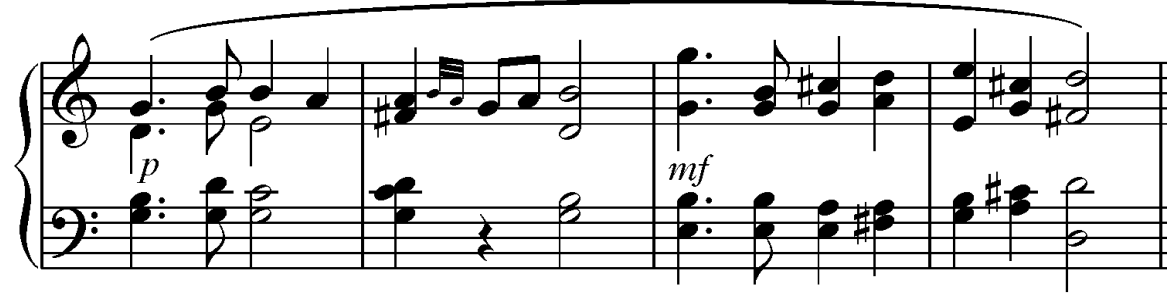

The closing theme begins in $\mathrm{m} .36$ in the dominant. The A section is separated by the double bar line with repeat signs. After the A section is repeated, the B section begins with the first theme in the dominant key area and only modulates back to the tonic when the second theme is re-introduced in m. 61 . This B section concludes with the closing theme in the key of C Major (see example 4.1.4).

Example 4.1.4: Sonata in C Major "Allegro Moderato" ( $1^{\text {st }}$ movement): closing theme (mm. 37-44).
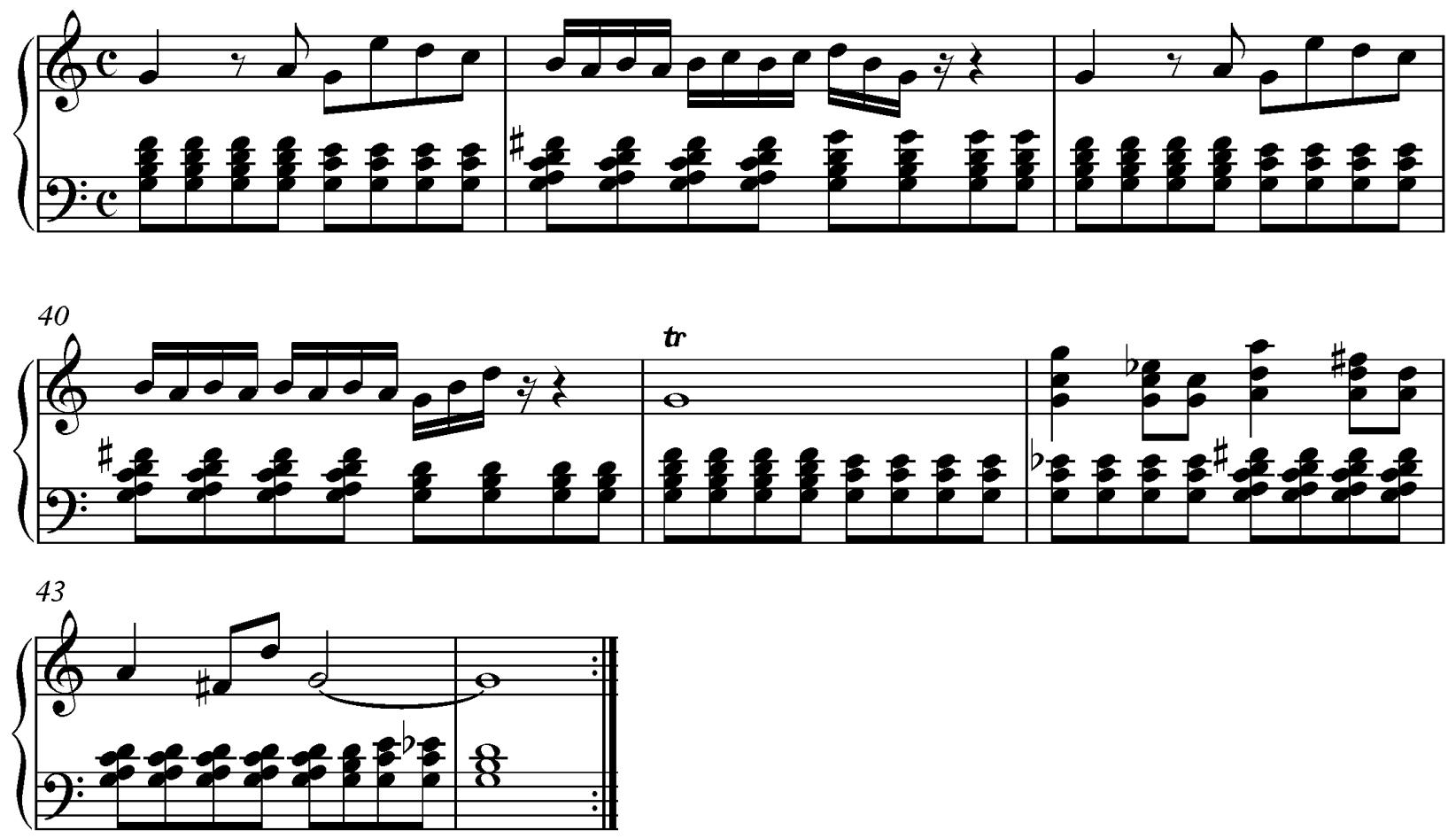
The second movement: Andante

This movement is written in a binary form and is in $2 / 4$ meter. A brief analysis of the movement is presented in the table below:

\begin{tabular}{|c|c|c|c|c|c|c|c|}
\hline \multicolumn{4}{|l|}{ A section } & \multicolumn{4}{|l|}{ |l: B section } \\
\hline A theme & & $\mathrm{A}^{\prime}$ & $\mathrm{A}$ & A theme & & $\mathrm{A}^{\prime}$ & $\mathrm{A}^{\prime \prime}$ \\
\hline $\begin{array}{l}\text { 1st ending:\| } \\
\mathrm{mm} .1-8\end{array}$ & $\begin{array}{l}2^{\text {nd }} \text { ending } \\
m m . \\
1-(9-10)\end{array}$ & $\begin{array}{l}\mathrm{mm} . \\
11-18\end{array}$ & $\begin{array}{l}\mathrm{mm} . \\
19-26\end{array}$ & $\begin{array}{l}\text { 1st ending:\|| } \\
\mathrm{mm} .27-34\end{array}$ & $\begin{array}{l}2^{\text {nd }} \text { ending } \\
\text { mm. } \\
27-(35-36)\end{array}$ & $\begin{array}{l}\mathrm{mm} . \\
37-44 \\
\end{array}$ & $\begin{array}{l}\mathrm{mm} . \\
45-52\end{array}$ \\
\hline Key: Fm & Fm & A-flat M & $\mathrm{Fm}$ & D-flat M & D-flat M & FM & $\mathrm{Fm}$ \\
\hline
\end{tabular}

This movement has two main sections: each consists of twenty-four measures and uses the same motivic melodic material that supplies the entire movement. In each section, the melody line is reiterated three times and only varied by the left hand accompaniment. The texture of this movement progressively gets fuller. The key relationship is mainly a third apart from its original key of F minor (see example 4.1.5)

Example 4.1.5: Sonata in C Major "Andante" ( $2^{\text {nd }}$ movement): A theme (mm.1-8)

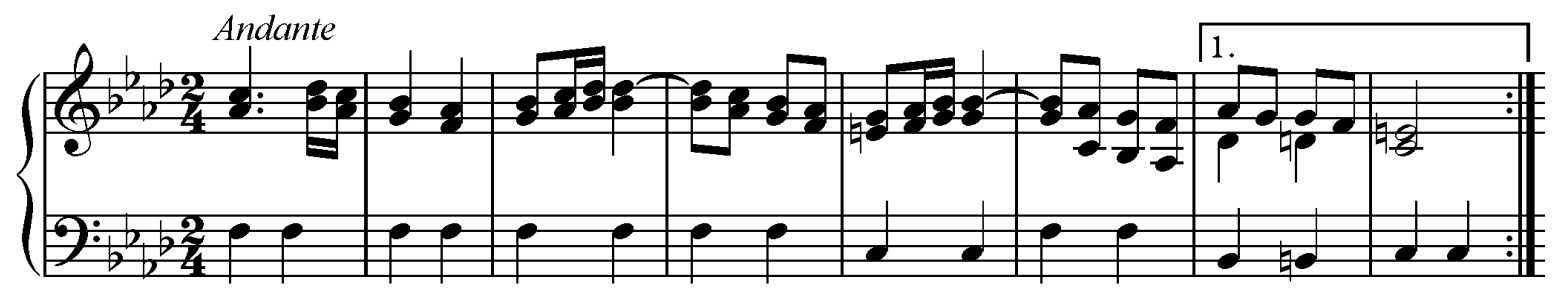

The arrows (below) indicate where the natural sign is added on the note E. They are missing in the manuscript. It is unknown why they were missing, but the harmonic progression will make more sense if the note $\mathrm{E}$ is E-natural (see example 4.1.6).

Example 4.1.6: Sonata in C Major "Andante" ( $2^{\text {nd }}$ movement): A' theme (mm. 33-40). mm. 33- 40

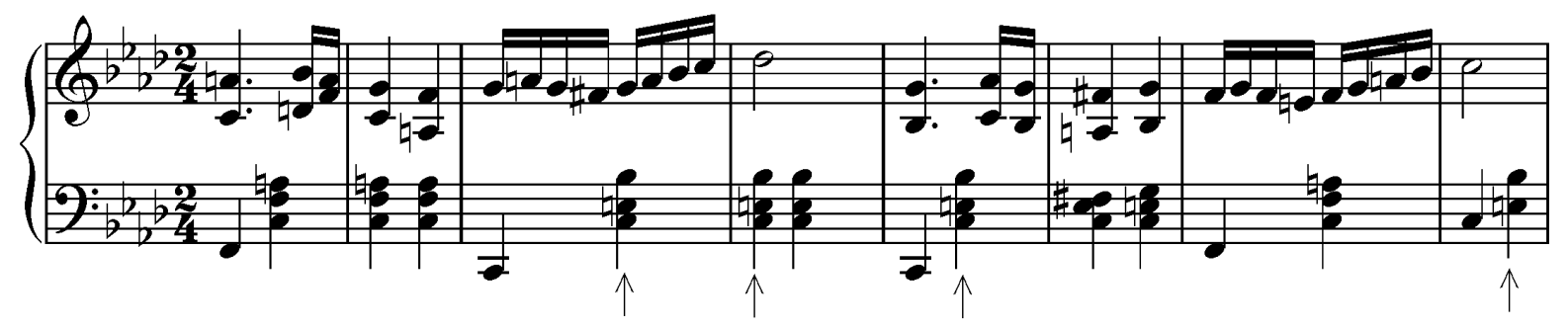




\section{The third movement: Menuetto Allegretto and Trio}

This movement is written in a ternary form that consists of Minuet and Trio and is in 3/4 meter. A brief analysis of the movement is presented in the table below:

\begin{tabular}{|l|l|l|l||l|l||}
\hline \multicolumn{2}{|l|}{ Minuet } & \multicolumn{2}{l|}{ Trio } & Minuet \\
\hline $\begin{array}{l}\text { Minuet theme: } \\
\text { mm. 1-8 }\end{array}$ & $\begin{array}{l}\text { Minuet theme } \\
\text { mm. 9-16 }\end{array}$ & $\begin{array}{l}\text { Trio theme } \\
\text { mm. 17-28 }\end{array}$ & $\begin{array}{l}\text { Trio Theme } \\
\text { mm.29-40 }\end{array}$ & $\begin{array}{l}\text { Minuet theme: } \| \\
\text { mm. 1-8 }\end{array}$ & $\begin{array}{l}\text { Minuet theme } \\
\text { mm. 9-16 }\end{array}$ \\
\hline Key: FM & FM & FM & & Key: FM & FM \\
\hline
\end{tabular}

The key remains in the same F Major key for the entire movement. Only the theme and texture are changed to show contrast between the Minuet (see example 4.1.7) and Trio section (see example 4.1.8).

Example 4.1.7: Sonata in C Major "Menuetto- Allegretto" (3rd movement): Minuet theme (mm. 1-4).

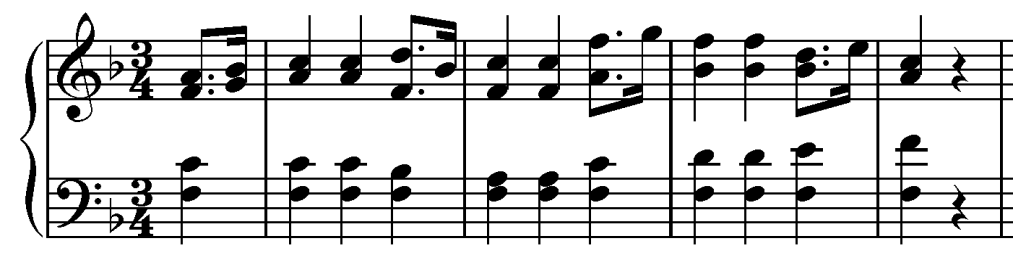

Example 4.1.8: Sonata in C Major "Menuetto- Allegretto" (3rd movement): trio theme (mm. 18-24)

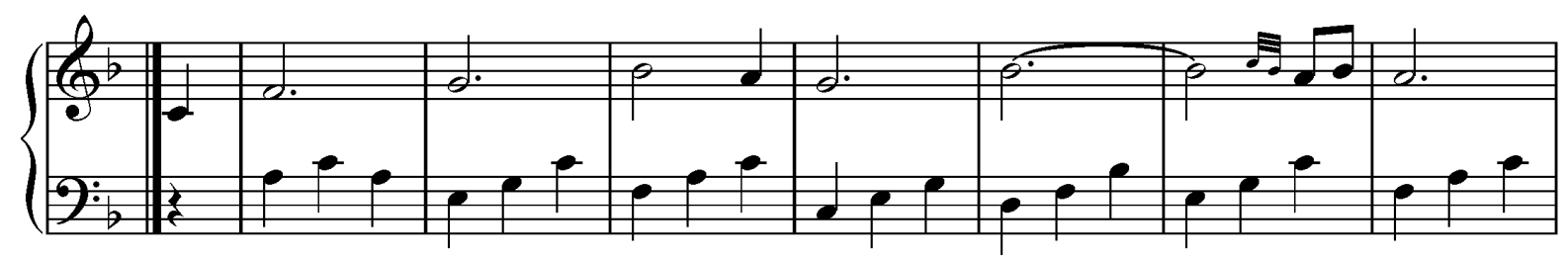

The Fourth movement: Rondo Allegretto

This movement (as indicated) is written in Rondo form and is in rapid 6/8 meter. A brief analysis of the movement is presented in the table below:

\begin{tabular}{|l|l|l|l|l|l|l|}
\hline A theme & & & & & & \\
\hline $\mathrm{mm} .1-8$ & $\mathrm{~mm} .9-16$ & $\mathrm{~mm} .17-28$ & $\mathrm{~mm} .29-33$ & $\mathrm{~mm}$. 34-40 & $\mathrm{mm} \cdot$ 41-48 & $\mathrm{mm} \cdot$ 49-52 \\
\hline Key CM & C minor & $\mathrm{G} \# \mathrm{~m}$ & $\mathrm{BM}$ & $\mathrm{CM}$ & $\mathrm{CM}$ & $\mathrm{CM}$ \\
\hline
\end{tabular}

Unexpectedly, no other themes are ever introduced after the first theme (see example 4.1.9). 
Example 4.1.9: Sonata in C Major "Allegretto" ( $4^{\text {th }}$ movement): A theme (mm. 1-4).

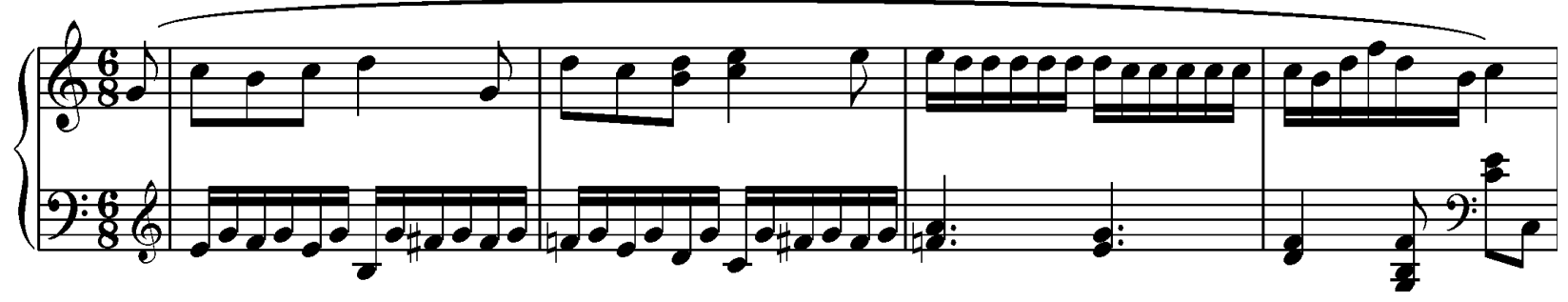

Rather, he keeps modulating each time the melody reiterates. Some modulation goes through the circle of fifths (mm. 25-26), and some modulation seems abrupt or to remote keys. The melodic phrasing is primarily regular. However, there are some irregular phrasings: for instance mm.2933 has only five measures and mm. 34-40 has seven measures. This movement ends with a surprisingly abrupt conclusion which needs an interpreter's idea to improve it, perhaps with a ritardando at the ending (see example 4.1.10)

Example (4.1.10): Sonata in C Major "Allegretto" ( $4^{\text {th }}$ movement): A theme (mm. 49-52)

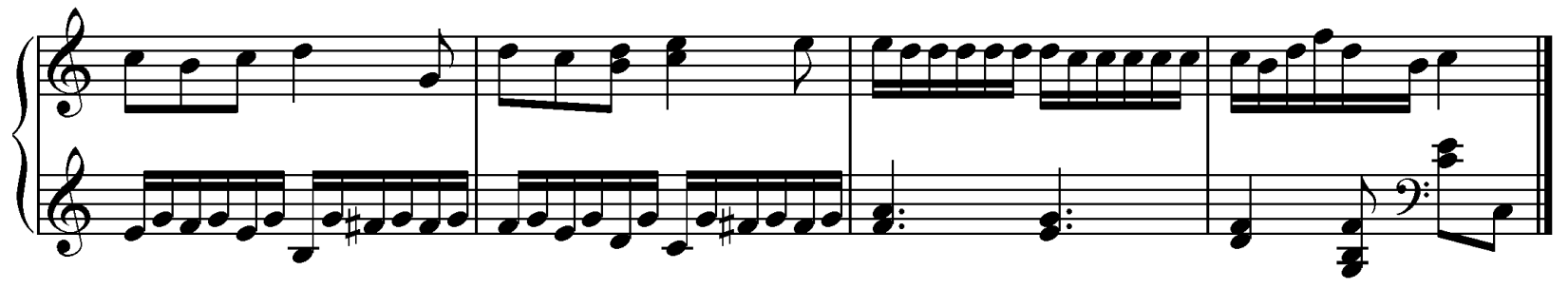




\section{(2) Sonata in $\mathbf{C}$ minor}

This sonata was composed in May 1881, six months after he finished composing the C Major Sonata. ${ }^{38}$ It is apparent in a short period of time that the young Stenhammar made great progress and started to write in the formal structure of the sonata. This sonata is in threemovements.

The first movement: Allegro

This movement is written in Sonata-Allegro form and is in 4/4 meter. A brief analysis of the movement is presented in the table below:

\begin{tabular}{|c|c|c|c|c|c|c|c|}
\hline \multicolumn{2}{|l|}{ Exposition } & \multicolumn{4}{|c|}{ \|: Development } & \multicolumn{2}{|c|}{ Recapitulation } \\
\hline Theme 1 & Theme 2 & Theme 1 & Theme 2 & Theme 1 & Theme 2 & Theme 1 & Codetta \\
\hline Key: Cm & $\mathrm{Cm}$ & A-flat M & $\mathrm{Gm}$ & GM & E-flat M & $\mathrm{Cm}$ & CM- Cm \\
\hline mm. 1-12 & $13-28$ & $29-40$ & $41-56$ & $57-72$ & $73-89$ & $90-105$ & 106- 119 \\
\hline
\end{tabular}

The first theme begins with an ascending broken-chord arpeggio in unison, followed by a righthand tremolo passage from mm. 5- 12 (see example 4.2.1). This creates a forward moving effect. Each measure is indicated $m f$. Perhaps, Stenhammar expected a diminuendo in each measure.

Example 4.2.1: Sonata in C minor "Allegro" ( $1^{\text {st }}$ movement): $1^{\text {st }}$ theme (mm. 1-7).

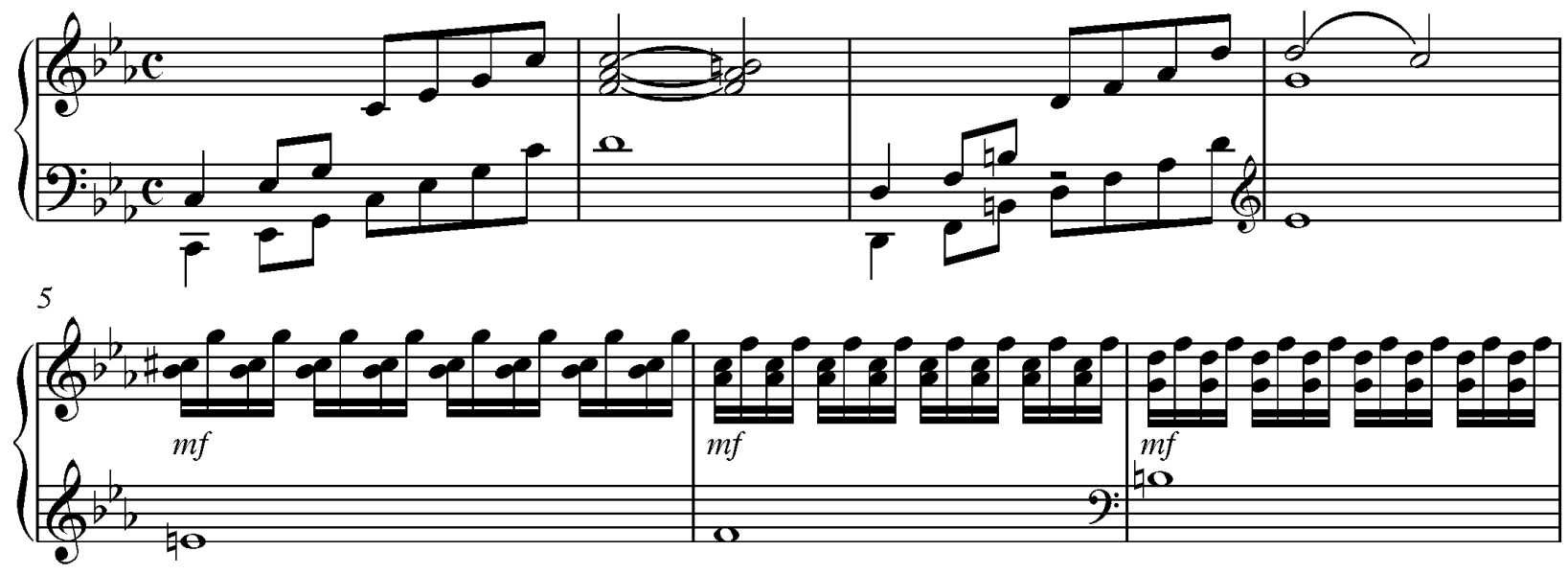

\footnotetext{
${ }^{38}$ Per Skans, liner notes to Wilhelm Stenhammar, The complete Solo Piano Music Volume 2, BIS Records CD-634, 1995.
} 
The second theme begins in $\mathrm{m} .13$. The texture has changed to homophonic. It sounds more lyrical and less active because of the longer note values (see example 4.2.2).

Example 4.2.2: Sonata in C minor "Allegro" ( $1^{\text {st }}$ movement): theme 2 (mm. 13-20).
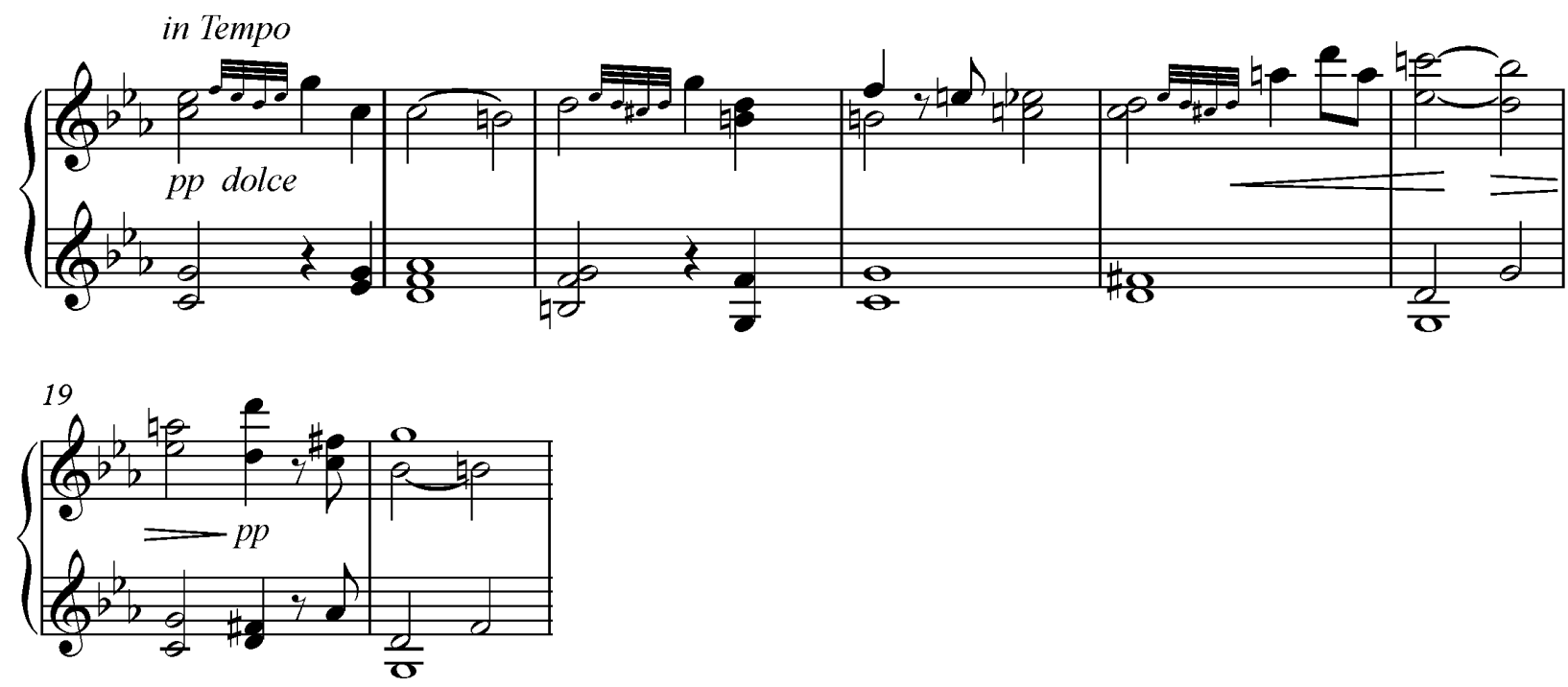

In the Development section, the first and second themes are presented in different keys.

Stenhammar used the modulation technic of the circle of fifths before returning to the home key of $\mathrm{C}$ minor in the Recapitulation section. The second theme is not reintroduced and he uses a codetta to conclude this movement. Another interesting feature in this sonata is that both Development and Recapitulation section are to be repeated together.

The second movement: Andante

This slow movement is written in binary form and is in 3/4 meter. A brief analysis of the movement is presented in the table below:

\begin{tabular}{|c|c|c|c|c|c|}
\hline \multicolumn{3}{|l|}{ A section } & \multicolumn{3}{|l|}{ A' section } \\
\hline A theme : $\|$ & B theme & Transition & A theme & B theme & A theme \\
\hline $\begin{array}{l}\text { mm. 1-12 } \\
\text { A-flat Major }\end{array}$ & mm. 13-34 & mm. 35-47 & $\begin{array}{l}\text { mm. 48-54 } \\
\text { A-flat Major }\end{array}$ & mm. $55-70$ & mm. $69-80$ \\
\hline
\end{tabular}

This movement is almost improvisatory-like with the melody line in the right hand and accompaniment in the left hand. The A theme starts in the key of A-flat Major. In the A section, 
the melody line is accompanied by descending bass notes with longer note values. The musical phrase structure is: A theme (5+7) (see example 4.2.3 and 4.2.4), B theme (12+10) (see example 4.2.5), and Transition (9+4). The A section concludes in the dominant of A-flat Major.

Example 4.2.3: Sonata in C minor "Andante" ( $2^{\text {nd }}$ movement): A theme (mm. 1- 5)

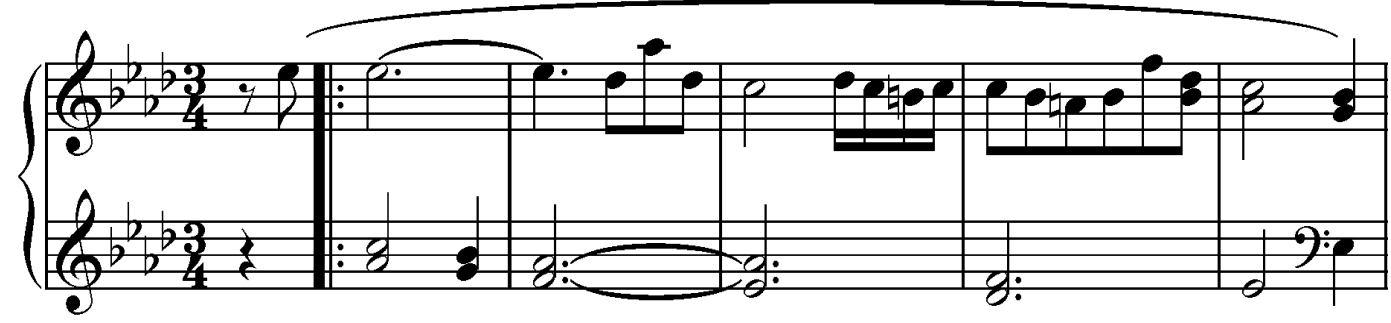

Example 4.2.4: Sonata in C minor "Andante": $2^{\text {nd }}$ movement $-A$ theme (mm. 6- 12)

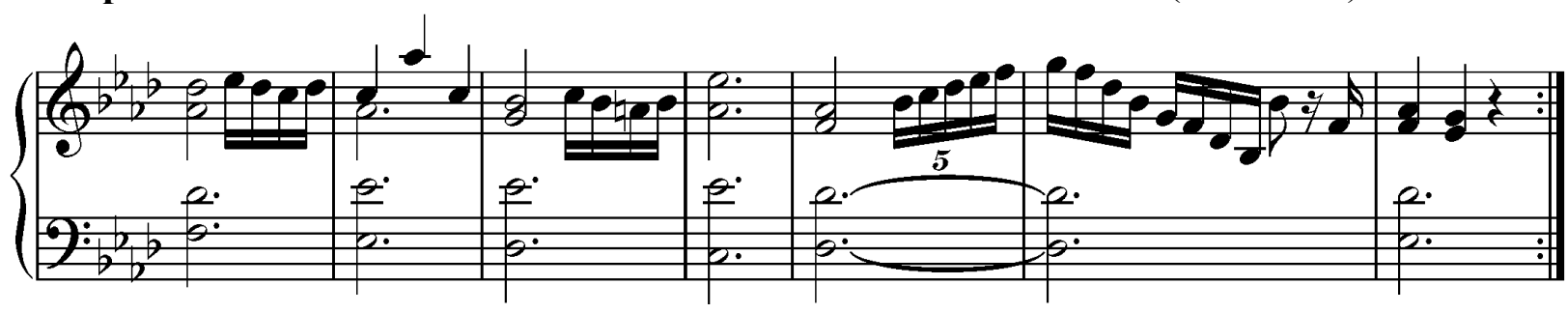

Example 4.2.5: Sonata in C minor "Andante": $2^{\text {nd }}$ movement- B theme (mm. 13-24)
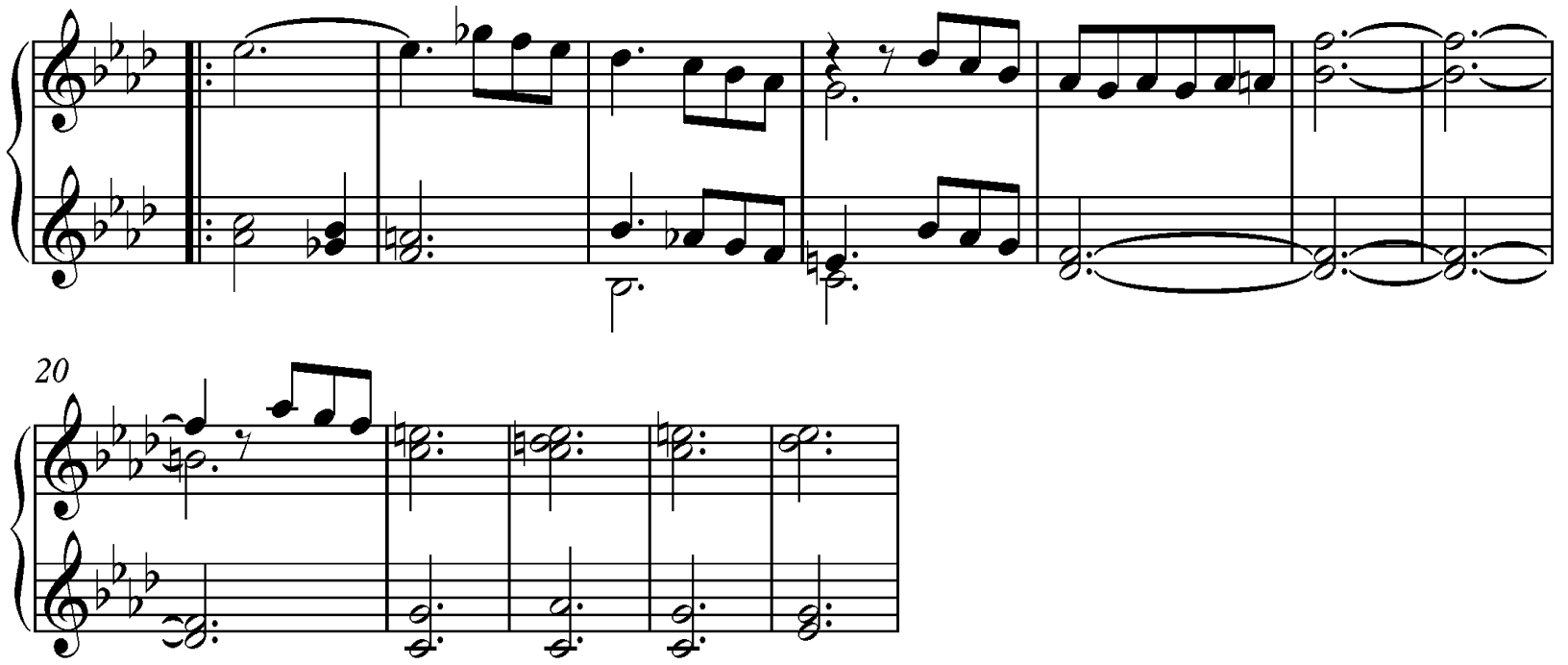

The $\mathrm{A}^{\prime}$ section uses materials from the A section and the A theme returns for the last time in $\mathrm{m} .60$ to conclude this movement. The accompanying motive has added Alberti-bass over the descending notes that were previously used in the A section. 
The third movement: Allegro

This movement is written in binary form with a Coda and is in 3/4 meter. A brief analysis of the movement is presented in the table below:

\begin{tabular}{|c|c|c|c|c|c|}
\hline \multicolumn{3}{|l|}{ A } & \multicolumn{3}{|l|}{$\mathrm{A}^{\prime}$} \\
\hline Theme 1 : & Theme 2 & Transition & Theme 1 & Theme 2 & Transition \\
\hline $\begin{array}{l}\mathrm{mm} .1-16 \\
\mathrm{C} \text { minor }\end{array}$ & mm. 17-32 & $\begin{array}{l}\mathrm{mm} .33-48 \\
\mathrm{GM}\end{array}$ & $\begin{array}{l}\mathrm{mm} .49-63 \\
\mathrm{Cm}\end{array}$ & $\begin{array}{l}\mathrm{mm} .64-84 \\
\text { A-flat Major }\end{array}$ & $\begin{array}{l}\mathrm{mm} .85-96 \\
\mathrm{GM}\end{array}$ \\
\hline
\end{tabular}

\begin{tabular}{|l|l|}
\hline Extension \\
\hline Theme 1 & Coda \\
mm. 97-104 & mm. 105-112 \\
Cm & $\mathrm{Cm}$ \\
\hline
\end{tabular}

After the slow lyrical second movement, this movement begins with a more energetic and quick right hand sixteenth-note figuration (see example 4.2.6). This first theme is also very similar to Mozart's piano sonata in C major, K. 545: the closing theme of the first movement.

Example 4.2.6: Sonata in C minor "Allegro": Finale- the First theme (mm 1-4)

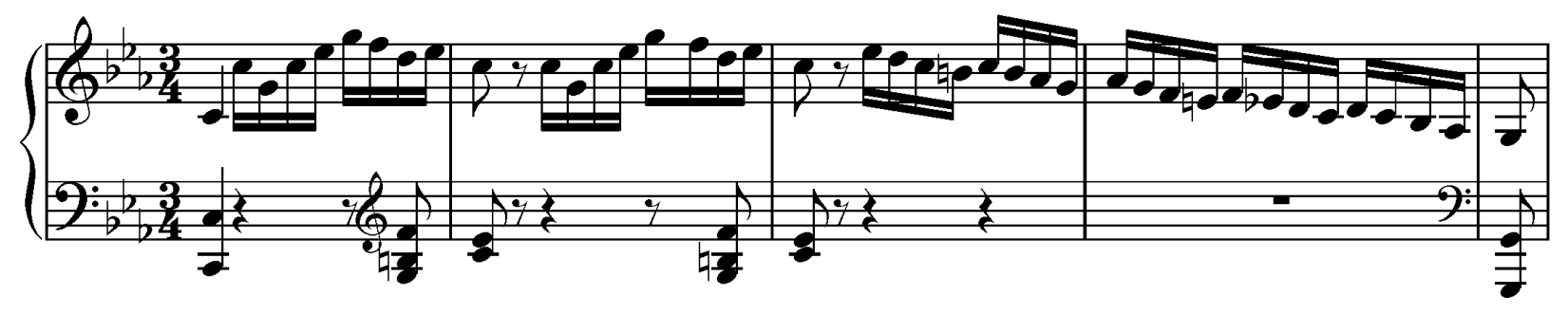

Example 4.2.7 Mozart: Sonata in C Major, K. 545 ( $1^{\text {st }}$ movement $)$ : Closing theme (mm.26-28).

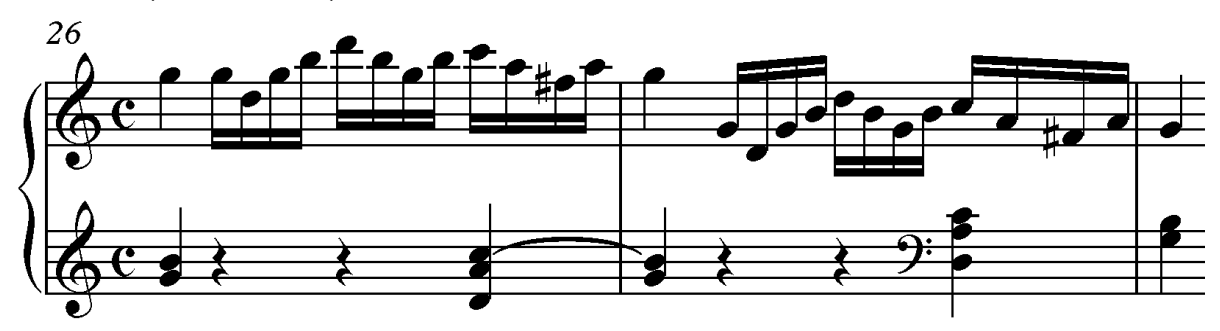

The second theme begins in $\mathrm{m} .17$ and is in a $\mathrm{C}$ tonal center. It is unstable in that it implies C Major and C minor at the same time (see example 4.2.8). This shows that Stenhammar 
has expanded his compositional technic by using chromaticism and borrowed chords. This technic helps create a more expressive and dramatic effect.

Example 4.2.8: Sonata in C minor "Allegro" (Finale): Second theme (mm. 17-24).
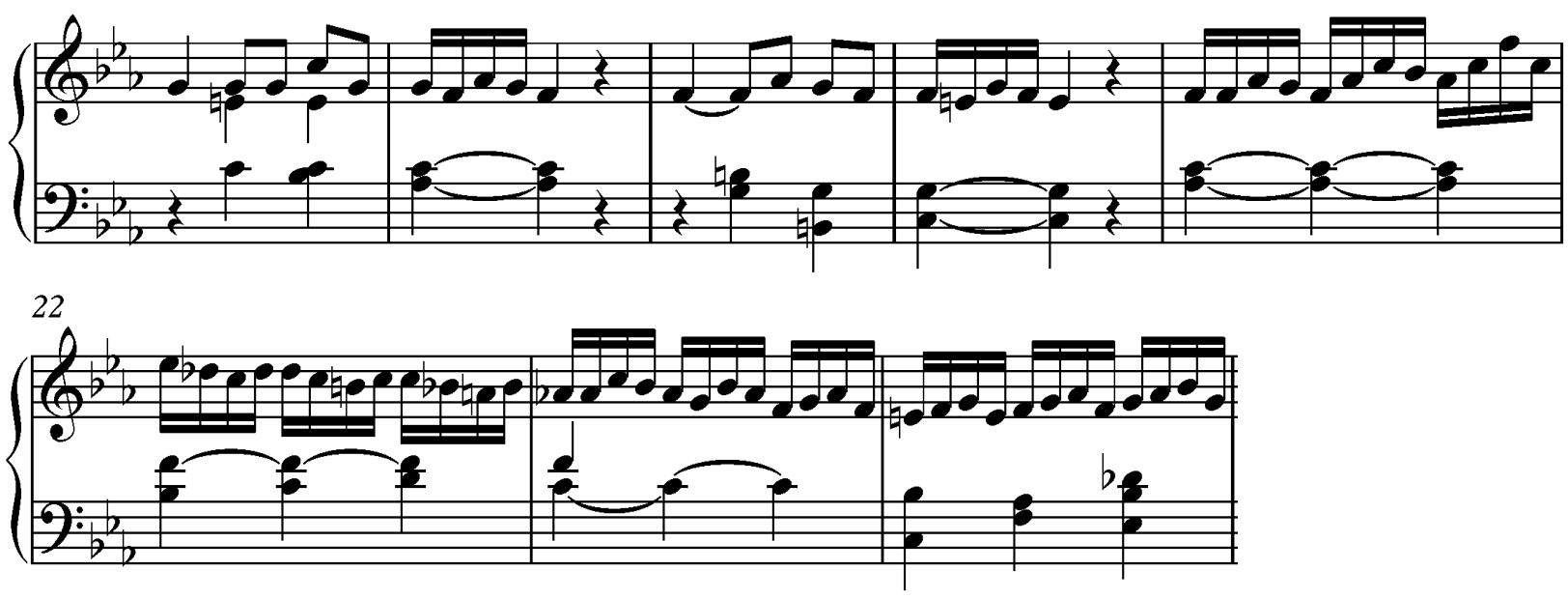

The A' section uses materials from the A section. The first theme is in the key of C minor, whereas the second theme is now in the A-flat tonal center (third relationship). The first theme returns for the last time in $\mathrm{m} .97$ as the movement concludes with the coda in m. 105. The coda provides an extension of chromatic chord progressions: VI | VI 4/2 | N6 | N6 | I 6/4 |V| I before it finally resolves in the key of $\mathrm{C}$ minor (see example 4.2.9).

Example 4.2.9: Sonata in C minor "Allegro" (Finale): Coda (mm. 105-112).
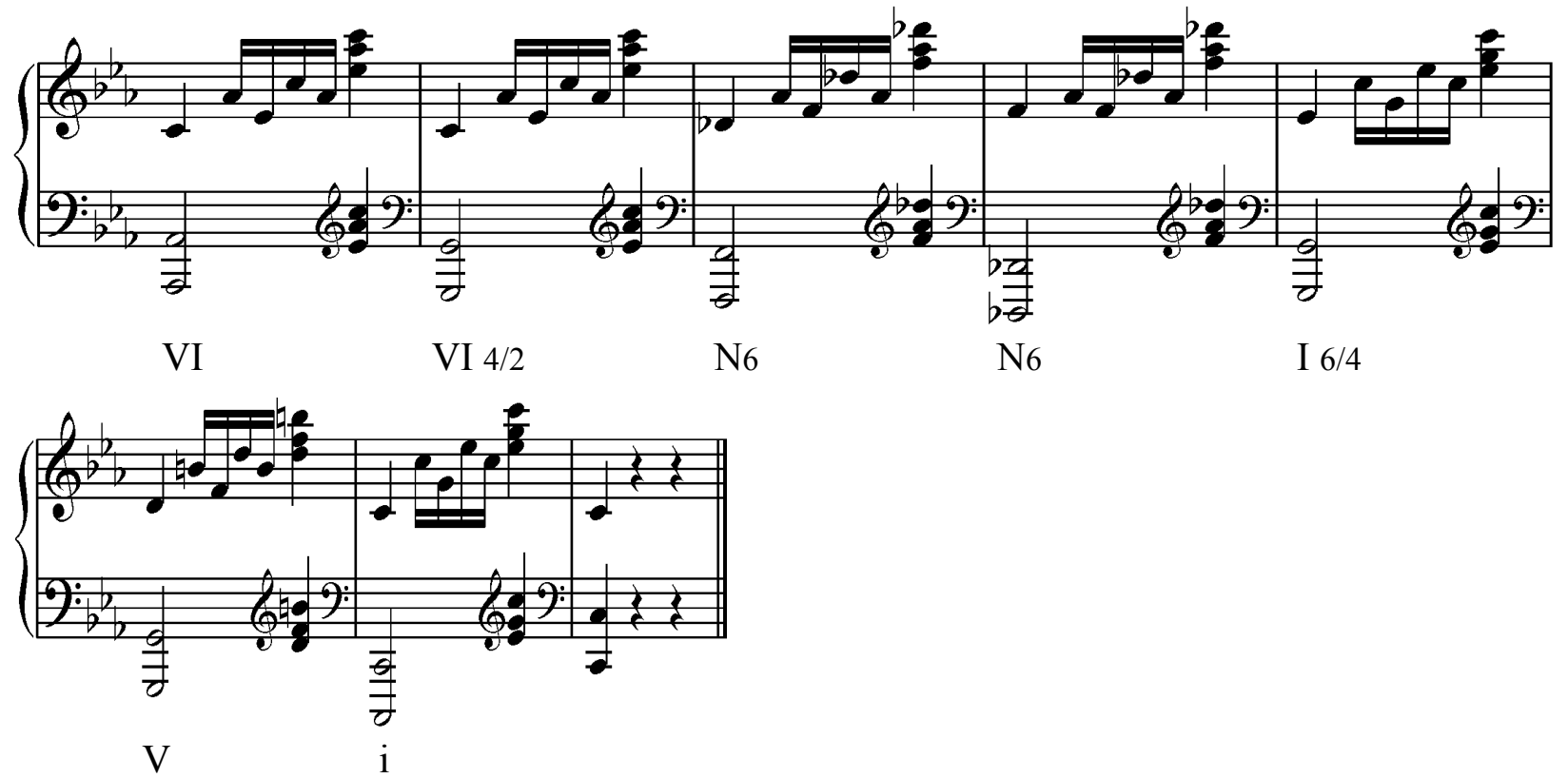


\section{(3) Sonata in A-flat Major}

This sonata was composed in May/June 1883 and concludes the group of three early sonatas. The sonata in A-flat Major is in four movements.

The first movement: Allegro

This movement is written in Sonata-Allegro form and is in $4 / 4$ meter. A brief analysis of the movement is presented in the table below:

\begin{tabular}{|l|l|l|l|l|}
\hline \multicolumn{2}{|l|}{ Exposition } & & \|l: Closing theme : & \\
\hline $1^{\text {st }}$ theme & & & mm. 59-67 & mm. 68-79 \\
mm. 1- 23 & $\mathrm{mm} .24-47$ & $\mathrm{~mm} .48-58$ & & A-flat m \\
& & & A-flat M & i \\
A-flat M & & $\mathrm{I}$ & $\mathrm{I}$ & $\mathrm{V}$ \\
$\mathrm{I}$ & & $\mathrm{V}$
\end{tabular}

\begin{tabular}{|l|l|l|}
\hline \multicolumn{2}{|l|}{ Development } \\
\hline $1^{\text {st }}$ theme & Closing theme & New material \\
\hline mm. 80-103 & mm. 104- 120 & mm. 121-136 \\
& E-flat Major & E-flat major \\
$\begin{array}{l}\text { A-flat Major } \\
\text { I }\end{array}$ & V & V \\
\hline
\end{tabular}

\begin{tabular}{|c|c|c|c|c|c|}
\hline \multicolumn{6}{|l|}{ Recapitulation } \\
\hline $1^{\text {st }}$ theme & & New material & $1^{\text {st }}$ theme $: \|$ & Closing theme & Theme 1 \\
\hline $\mathrm{mm} .137-155$ & mm. 156-162 & mm. 163-184 & mm. 185-192 & mm. 193-204 & $\begin{array}{l}\text { mm. 205-215 } \\
\text { I }\end{array}$ \\
\hline $\begin{array}{l}\text { A-flat minor } \\
\text { I }\end{array}$ & $\begin{array}{l}\text { E-flat M } \\
\text { V }\end{array}$ & $\begin{array}{l}\text { A-flat Major } \\
\text { I }\end{array}$ & $\begin{array}{l}\text { A-flat Major } \\
\text { I }\end{array}$ & $\begin{array}{l}\text { A-flat M } \\
\text { I }\end{array}$ & \\
\hline
\end{tabular}

The Exposition has only one theme and is mainly distinguished by the dotted rhythm motif (see example 4.3.1). Since there is no contrasting theme, this section can be labeled as a monothematic exposition. One theme is continually used throughout the entire movement. It starts in the key of A-flat Major, moves to the dominant in m. 24, and returns to tonic in $\mathrm{m} .48$. 
Example 4.3.1: Sonata in A-flat Major “Allegro" ( $1^{\text {st }}$ movement): $1^{\text {st }}$ theme (mm. 1-8).

Allegro
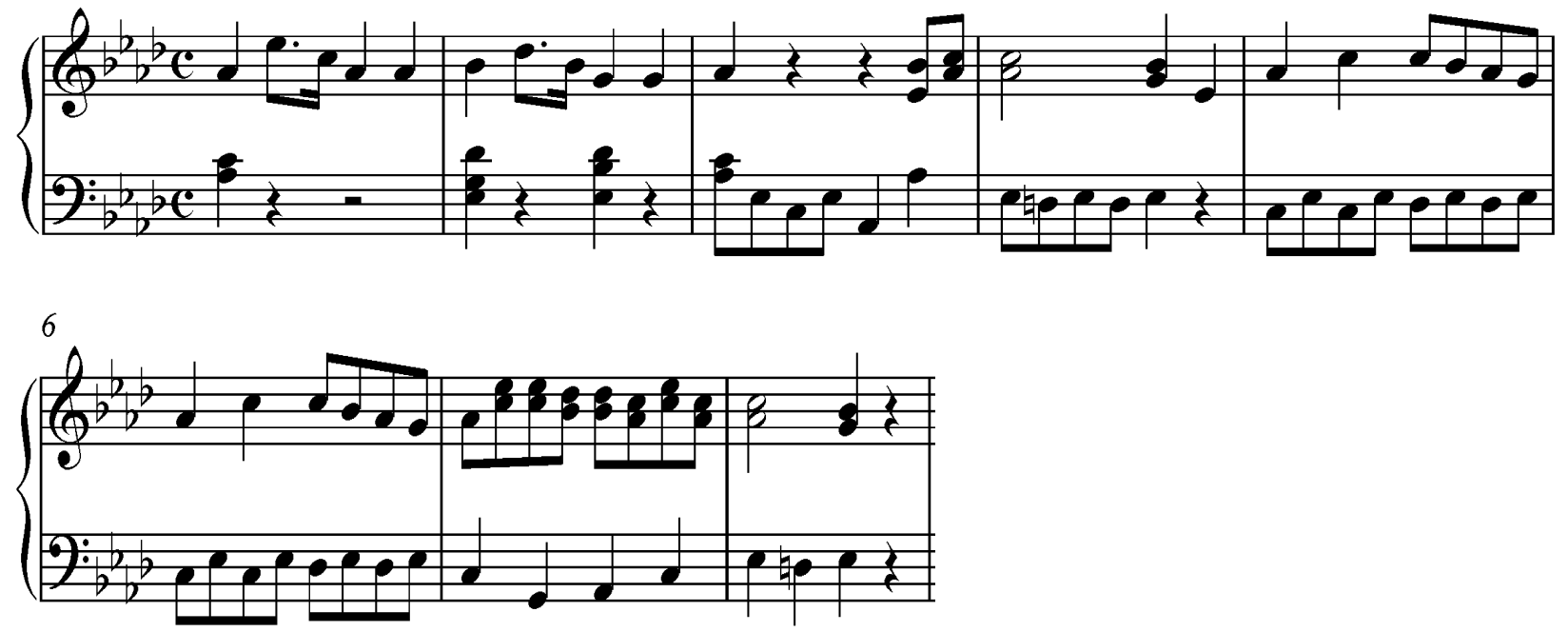

The Exposition concludes with the closing theme in $\mathrm{m} .59$ (see example 4.3.2) and is reiterated three times. The first and second time (repeat sign), they are in A-flat Major and lastly, it is in A-flat minor.

Example 4.3.2: Sonata in A-flat Major “Allegro" ( $1^{\text {st }}$ movement): closing theme (mm. 59-66).
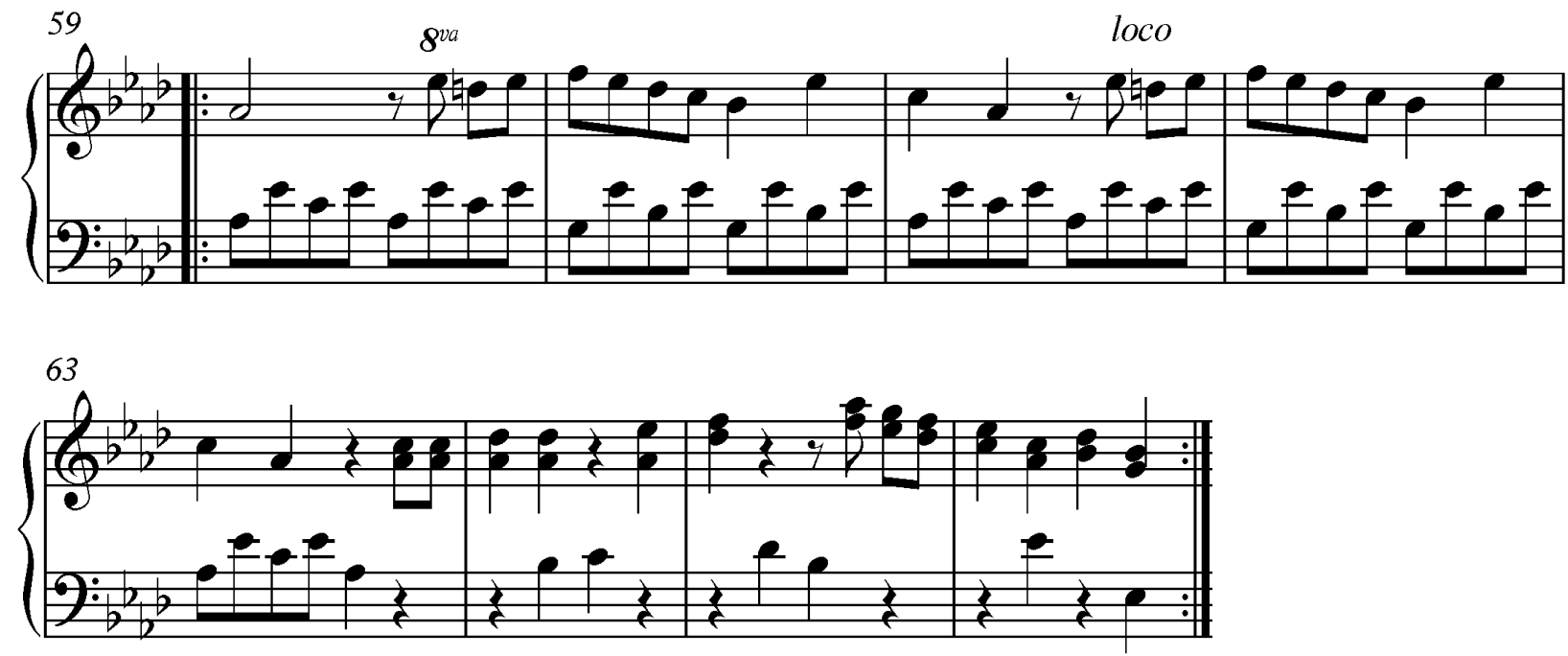

The Development section opens with the first theme in the key of A-flat Major, followed by the closing theme in $\mathrm{m} .103$ now in the dominant key. New material is introduced in $\mathrm{m} .121-$ 136 (see example 4.3.3) and begins in the key of E-flat (dominant key of A-flat Major). 
Example 4.3.3: Sonata in A-flat Major “Allegro" (1 $1^{\text {st }}$ movement): New material (mm. 121-124).

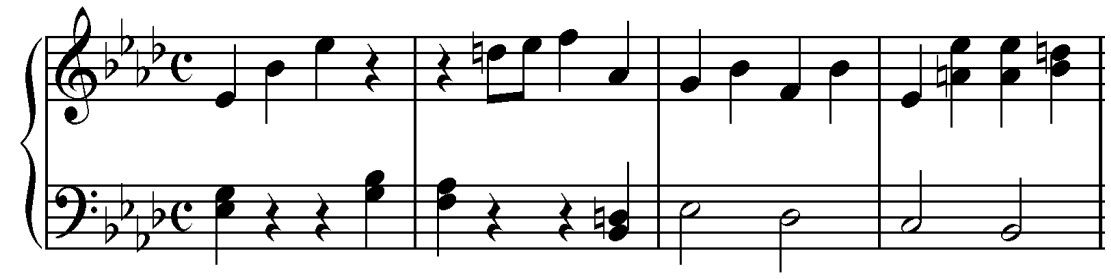

In the Recapitulation, the themes are all presented in order of theme 1 , new theme, and closing theme. They are presented in the tonality of A-flat and E-flat. The first theme is presented for the last time in m. 205 in the key of A-flat Major and concludes with a minor plagal cadence (iv 6/4- I).

The second movement: Adagio Grazioso

This movement is written in binary form and is in 6/8 meter. A brief analysis of the movement is presented in the table below:

\begin{tabular}{|c|c|c|c|c|c|}
\hline \multicolumn{3}{|l|}{ A section } & \multicolumn{3}{|l|}{ A' section } \\
\hline Theme 1 & Theme 2 & Theme 1 & Theme 1 & Theme 1 & Theme 1 \\
\hline mm. 1-15 & mm. 16-29 & mm. 30-37 & mm. 38-50 & mm.51-69 & $\mathrm{mm} .60-73$ \\
\hline $\begin{array}{l}\text { D-flat M } \\
\text { I }\end{array}$ & $\begin{array}{l}\text { Fm } \\
\text { iii }\end{array}$ & $\begin{array}{l}\text { D-flat M } \\
\text { I }\end{array}$ & $\begin{array}{l}\text { D-flat minor } \\
\text { I }\end{array}$ & $\begin{array}{l}\text { D-flat Major } \\
\text { I }\end{array}$ & $\begin{array}{l}\text { D-flat Major } \\
\text { I }\end{array}$ \\
\hline
\end{tabular}

The second movement opens with a peaceful cantabile first theme and is in the key of Dflat (see example 4.3.4). The second theme presents a more forward-moving thirty-second note accompaniment in the left hand (see example 4.3.5).

Example 4.3.4: Sonata in A-flat Major “Andante Grazioso" ( $2^{\text {nd }}$ movement $): 1^{\text {st }}$ theme (mm. 1- 4)

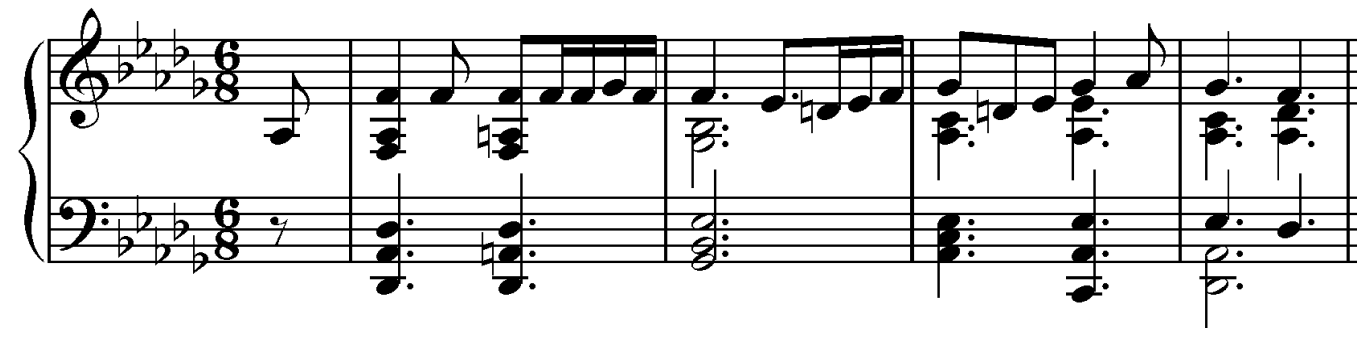


Example 4.3.5: Sonata in A-flat Major "Andante Grazioso" ( $2^{\text {nd }}$ movement $)$ : Second theme (mm. 16-21)

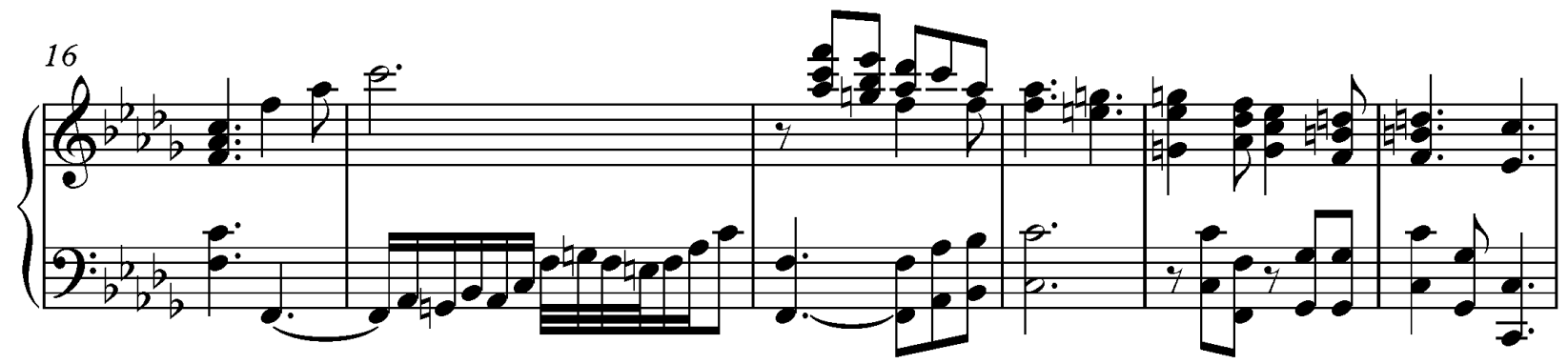

The third movement: Presto Marcato

This movement is written in ternary form and is in 3/4 meter. A brief analysis of the movement is presented in the table below.

\begin{tabular}{|c|c|c|c|c|c|c|c|}
\hline \multicolumn{2}{|l|}{ A section } & \multicolumn{3}{|l|}{ B section } & \multicolumn{3}{|l|}{$\mathrm{A}^{\prime}$ section } \\
\hline $1^{\text {st }}$ theme : & $2^{\text {nd }}$ theme & $1^{\text {st }}$ theme $: \|$ & $\|: 2^{\text {nd }}$ theme $: \|$ & Transition & $1^{\text {st }}$ theme & $2^{\text {nd }}$ theme & $1^{\text {st }}$ theme \\
\hline $\begin{array}{l}\mathrm{mm} \cdot 1-8 \\
\mathrm{Fm}\end{array}$ & mm. 9-24 & $\begin{array}{l}\mathrm{mm} \cdot 25-32 \\
\text { FM }\end{array}$ & mm. 33-40 & $\mathrm{mm} .41-56$ & $\begin{array}{l}\mathrm{mm} \cdot 57-64 \\
\mathrm{Fm}\end{array}$ & mm. 65-74 & mm. 75-82 \\
\hline
\end{tabular}

This movement opens with a more energetic and distinguished rhythmic motive in the first theme, which alternates the left hand and right hand (see example 4.3.6). As indicated Presto Marcato, the musical instruction requires a performer to play more weightily in the left hand. It carries strong bass notes ( $\mathrm{F}$ and $\mathrm{C}$ ) on each downbeat in every measure accompanying the double-note and triadic melodic line in the right hand. The first theme is in the key of F minor.

Example 4.3.6: Sonata in A-flat Major "Presto Marcato" ( $3^{\text {rd }}$ movement): First theme (mm. 1-8).

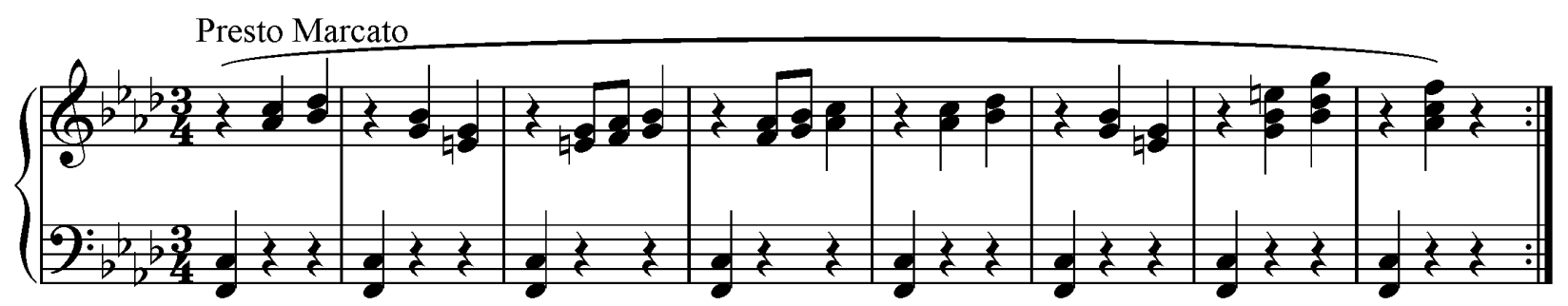

The second theme begins in $\mathrm{m} .9$ and is still in the key of F minor. The change of texture provides contrast for the second theme. Instead of alternating the left and right hand, now both 
hands will be played simultaneously (see example 4.3.7). The melodic line on the top notes needs to be brought out more over the thicker accompaniment.

Example 4.3.7: Sonata in A-flat Major "Presto Marcato" $\left(3^{\text {rd }}\right.$ movement): second theme (mm. 9-16)

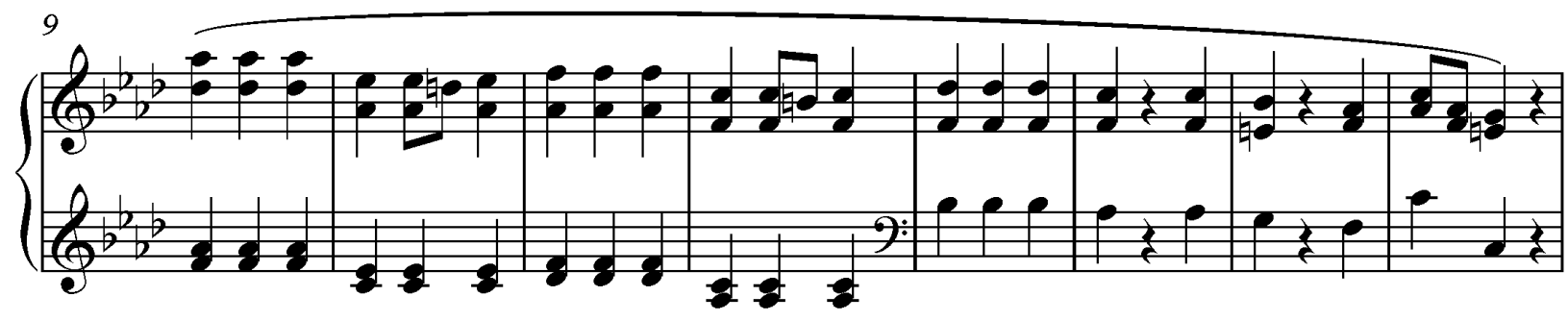

The B section uses the same material as the A section. The first and second themes are now in the key of F major (Parallel major of F minor). A transition in m. 41- 56 leads back to the $\mathrm{A}^{\prime}$ section, where all themes return. The first theme returns in F minor, the second theme returns in F Major, and the first theme finally concludes in F minor.

The fourth movement: Finale- Rondo. Allegretto

This movement is written in rondo form and is in $2 / 4$ meter. A brief analysis of the movement is presented in the table below.

\begin{tabular}{|l|l|l|l|l|l|l|l|}
\hline A theme & B theme & A theme & A' theme : & Il: A theme & B theme & A' theme & C theme \\
\hline $\mathrm{mm} .1-8$ & $\mathrm{~mm} .9-16$ & $\mathrm{~mm} .17-26$ & $\mathrm{~mm} \cdot 27-41$ & $\mathrm{~mm} .42-49$ & $\mathrm{~mm} .50-69$ & $\mathrm{~mm} .58-69$ & $\mathrm{~mm} .70-86$ \\
& & $\mathrm{Cm}$ & & & & & \\
A-flat M & A-flat M & & Aflat M- Fm & D-flat M & D-flat M & Fm & FM \\
\hline
\end{tabular}

\begin{tabular}{|l|l|l|l|l|l|l|l|}
\hline A theme & B theme & A theme & D theme & A theme & B theme & A theme & Coda \\
\hline mm.87-94 & $\mathrm{mm} .95-$ & $\mathrm{mm} .103-$ & $\mathrm{mm} .116-131$ & $\mathrm{~mm} .132-139$ & $\mathrm{~mm} .140-$ & $\mathrm{mm} .148-$ & $\mathrm{mm} .165-$ \\
& 102 & 115 & & & 147 & 164 & $\begin{array}{l}167 \\
\text { A-flat M } \\
\text { V M-I }\end{array}$ \\
\hline
\end{tabular}

The A theme is presented in a very lively motivic rhythm: key of A-flat Major. The melody line is in the right hand accompanied by the left hand and is in the $4+4$ phrase structure (see example 4.3.8). Both melody and accompaniment have a similar descending motion. This A theme re-appears several times in different keys throughout the entire movement. 
Example 4.3.8: Sonata in A-flat Major “Rondo- Allegretto” (Finale): A theme (mm. 1-8).
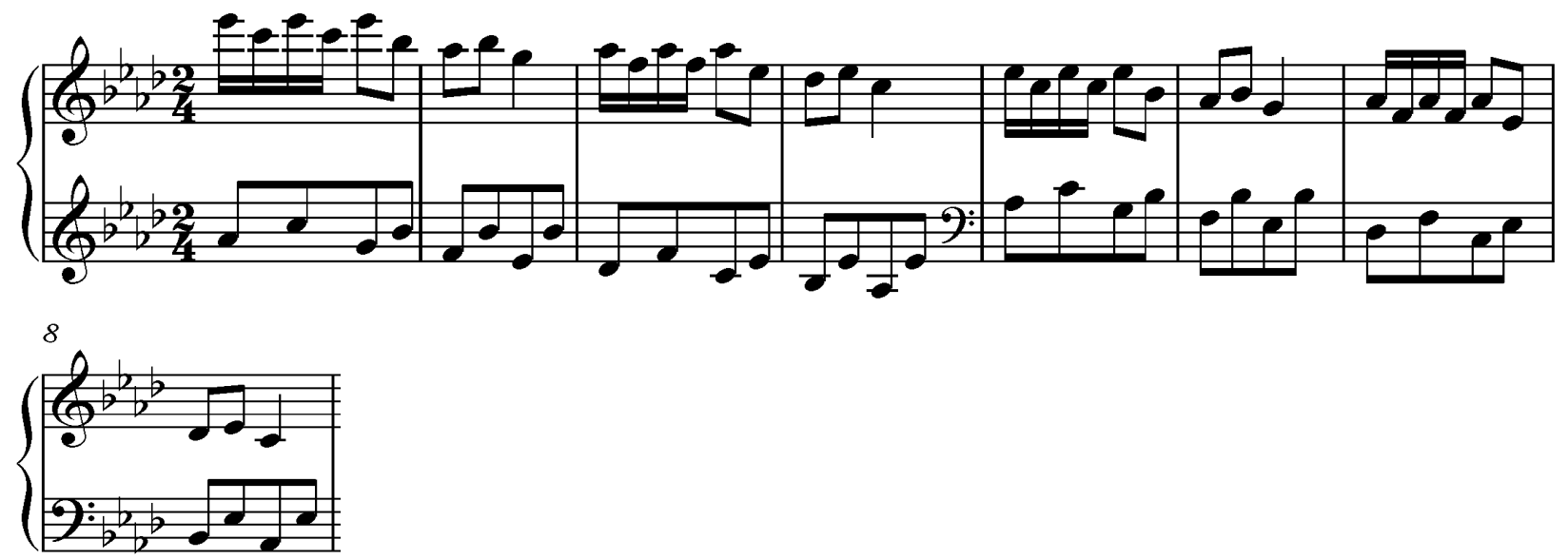

The B theme begins in $\mathrm{m} .9$ and is still in the key of A-flat Major before modulating to different key to anticipate the return of the A theme in $\mathrm{C}$ minor in $\mathrm{m}$. 17. The B theme (see example 4.3.9) has a more lyrical melodic line in the right hand and is accompanied by Alberti bass in the left hand.

Example 4.3.9: Sonata in A-flat Major "Rondo-Allegretto" (Finale): B theme (mm. 9-16).

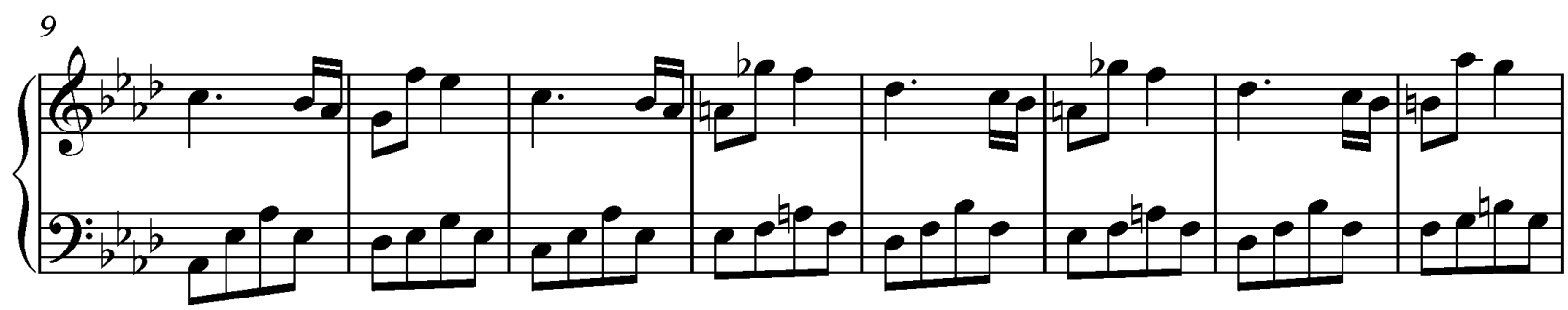

After the second presentation of the A theme from $\mathrm{m} .17-26$, a very similar motivic

rhythm appears in $\mathrm{m} .27-41$. The rhythmic motive .0 .0 in the A theme (descending) is now presented in the opposite contour (ascending) with different accompaniments including chords and Alberti bass. This $\mathrm{A}^{\prime}$ passage is in the key of $\mathrm{F}$ minor (the relative minor of A-flat Major) and is concluded with a strong F minor chord in fortissimo (see example 4.3.10). 
Example 4.3.10: Sonata in A-flat Major “ Rondo-Allegretto" (Finale): A' theme (mm. 27-41)
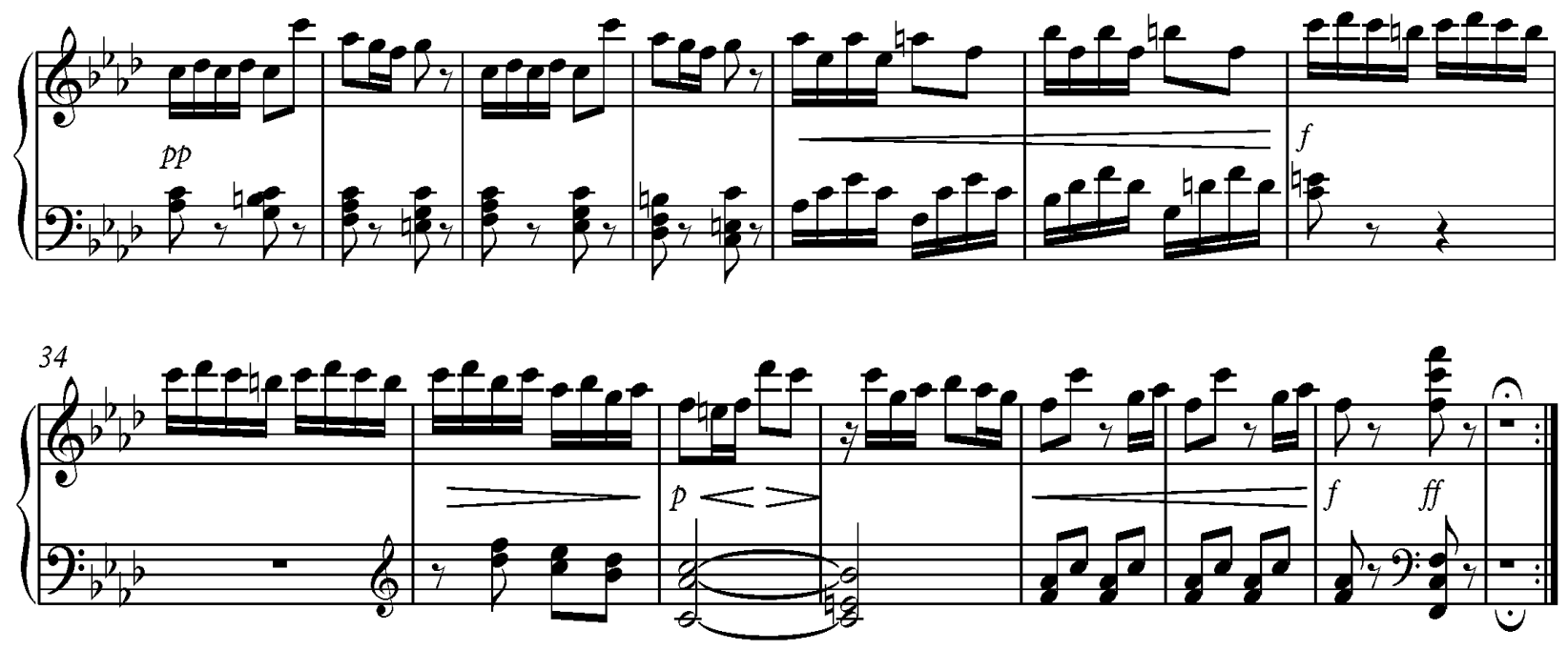

After a brief pause in $\mathrm{m} .41$, the $\mathrm{A}$ and $\mathrm{B}$ themes are re-introduced and are now

modulated to a remote key of D-flat Major. Immediately the $\mathrm{A}^{\prime}$ theme follows starting in $\mathrm{F}$ minor (m. 58) and ending in C Major (m. 69). New material is now introduced as the $\mathrm{C}$ theme and is in the key of F Major. Dynamic markings are specifically designated by Stenhammar and have a wide range in such a short phrase (see example 4.3.11). It is challenging for the performer to pace these dynamic to achieve the dramatic effect that is required by the composer.

Example 4.3.11: Sonata in A-flat Major, "Rondo-Allegretto" (Finale): C theme (mm. 70-78)

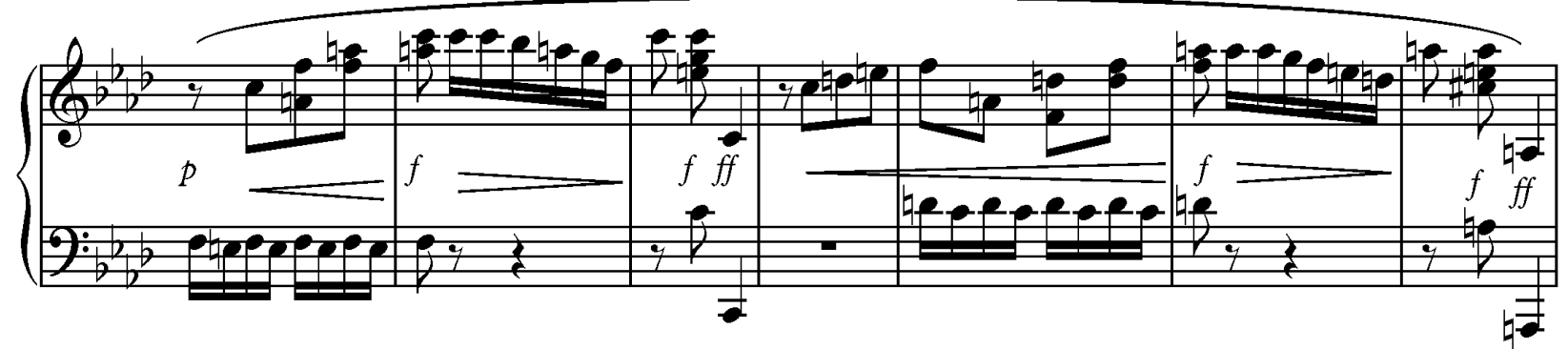

The A, B, and A theme are returned in the same order: mm. 87-131 and mm. 132- 167 with different concluding materials. In mm. 87-131, the key is now F Major and it concludes with a transitional passage in $\mathrm{mm} .116-131$. This provides a modulation from $\mathrm{F}$ tonality to E-flat which serves as a dominant (of A-flat) before returning to the home key of A-flat Major. 
In mm. 132, the A theme returns to the key of A-flat and finally concludes with a three-measure coda: an abrupt coda that emphasizes a strong V-I chord progression (see example 4.3.12).

Example 4.3.12: Sonata in A-flat Major "Rondo-Allegretto" (Finale): Coda (mm. 165-167)

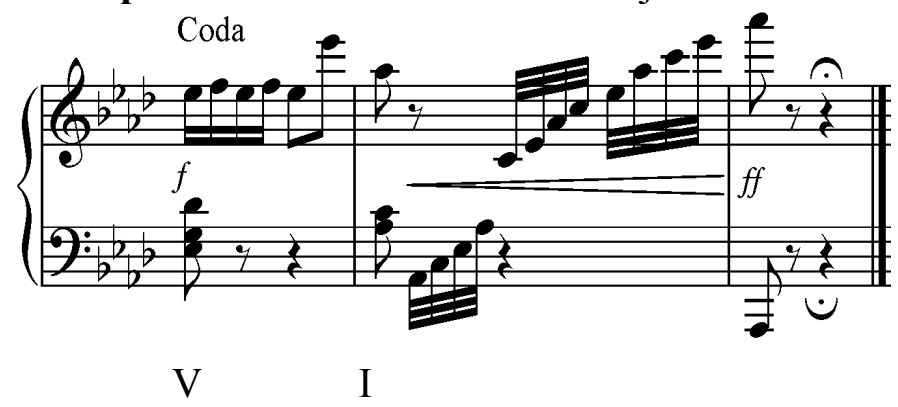




\section{(4) Sonata in G minor}

Stenhammar composed the Piano Sonata in G minor in the spring and summer of 1890. This sonata follows a traditional four-movement form that consists of: (I) Allegro Vivace e Passionato; (II) Andante quasi Adagio; (III) Scherzo and Trio; and (IV) Rondo. The approximate length of this sonata is about 25 minutes. Perhaps this could be regarded as Stenhammar's first mature piano composition. ${ }^{39}$ Stenhammar integrated and expanded different stylistic elements and this sonata exhibits a more sophisticated quality than in his earlier sonatas. These elements include the use of a more complex voicing, thicker chordal texture, more chromatic harmony and melodic line, and a wider scope of dynamic markings. The increase of technical demands and pianistic requirements become more evident as he developed into an excellent pianist.

This sonata seems to have strong similarities with Schumann's Sonata in G minor, Op. 22. Perhaps Stenhammar was aware of Schumann's sonata through his study with Andersson and later decided to model after it. The similarities between these two sonatas will be discussed later in Chapter 6. Despite the similarities, we still can find Stenhammar's personal harmonic and melodic language in this sonata as it defines his first mature work. The author believes this to be a very effective and expressive sonata. Like the rest of his solo piano works, Stenhammar never performed this sonata again after playing it at a charity concert in May $1891 .^{40}$

\footnotetext{
${ }^{39}$ This sonata was composed while he was studying composition with Emil Sjörgen and Andreas Hallén ${ }^{40}$ Martin Sturfät. “Wilhelm Stenhammar(1871-1927)_Piano Sonata in G minor (1890)” the Introduction (Stockholm: Musikaliska Konstföreningen, 2008), V.
} 
The first movement: Allegro Vivace e Passionate

This movement is written in a Sonata-Allegro form. The Exposition has 100 measures; the Development has 97 measures; and the Recapitulation and coda have 135 measures. A brief analysis of the movement is presented in the table below:

\begin{tabular}{|l|l|l|l|l|l||}
\hline Exposition & \multicolumn{2}{|l|}{} \\
\hline $\begin{array}{l}\text { Introduction } \\
\text { mm.1-6 }\end{array}$ & $\begin{array}{l}\text { Theme 1 } \\
\text { mm. 7-31 }\end{array}$ & $\begin{array}{l}\text { Transition } \\
\text { mm. 31-54 }\end{array}$ & $\begin{array}{l}\text { Theme 2 } \\
\text { mm.55-78 }\end{array}$ & $\begin{array}{l}\text { Closing } \\
\text { theme } \\
\text { mm.79-94 }\end{array}$ & $\begin{array}{l}\text { Introduction } \\
\text { mm.95-100 }\end{array}$ \\
G min & G min & $\begin{array}{l}\text { B-flat } \\
\text { Major } \\
\text { III }\end{array}$ & $\begin{array}{l}\text { D Major (dominant } \\
\text { of G minor) } \\
\text { V }\end{array}$ \\
\hline
\end{tabular}

\begin{tabular}{||l|l|l|l|l|l|l|l||}
\hline \multicolumn{2}{|l|}{ Development } \\
\hline $\begin{array}{l}\text { Intro } \\
\text { mm. }\end{array}$ & Transition & Intro & Theme 1 & Transition & New & New & Intro \\
m101-107 & $108-114$ & mm. & mm. & mm. & Theme & Theme & \\
& & $115-120$ & $121-132$ & $133-139$ & mm. & mm. & mm. \\
& & & & $140-165$ & $166-193$ & $194-197$ \\
G Major & & $\begin{array}{l}\text { A-flat } \\
\text { I }\end{array}$ & & & F minor & $\begin{array}{l}\text { B-flat } \\
\text { Major }\end{array}$ & $\begin{array}{l}\text { D Major } \\
\text { V }\end{array}$ \\
\hline
\end{tabular}

\begin{tabular}{|c|c|c|c|c|c|}
\hline \multicolumn{4}{|l|}{ Recapitulation } & \\
\hline & & & $\begin{array}{l}\text { Closing } \\
\text { theme }\end{array}$ & $\begin{array}{l}\text { Altered } \\
\text { transition }\end{array}$ & \\
\hline $\begin{array}{l}\text { mm. 198-219 } \\
\text { G minor }\end{array}$ & $\mathrm{mm} .220-243$ & $\begin{array}{l}\mathrm{mm} .244-267 \\
\text { G Major }\end{array}$ & mm. 268-283 & $\begin{array}{l}\mathrm{mm} .284-305 \\
\text { Dominant }\end{array}$ & $\begin{array}{l}\mathrm{mm} .305-332 \\
\mathrm{G} \text { minor }\end{array}$ \\
\hline
\end{tabular}

The sonata starts with a strong G minor block chord, followed by a series of block chords with the outer voices in contrary motion (see example 4.4.1). The descending octave in the left hand is similar to the motive of theme 1. With the chordal texture and V-I cadence, it establishes the intensity of the first theme as indicated by the composer "with passion". This introductory material reappears at the beginning of each section and coda. 
Example 4.4.1: Sonata in G minor "Allegro Vivace e Passionate" ( $1{ }^{\text {st }}$ movement): Introductory material (mm. 1-6)

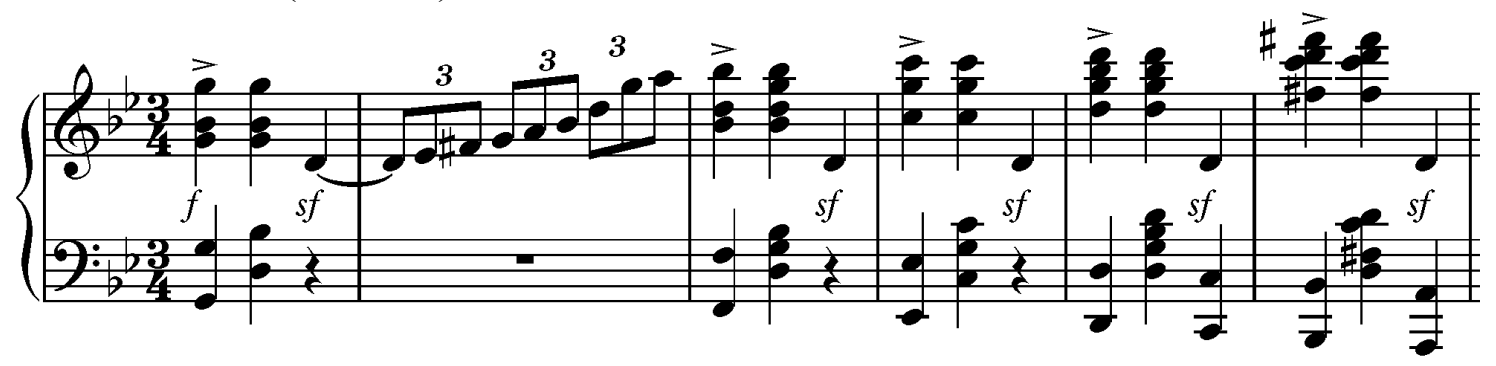

The Exposition consists of two contrasting themes: the first theme begins in $\mathrm{m} .7$; this section is passionate and energetic. The second theme begins in measure $\mathrm{m} .55$; this section is lyrical and tranquil. After a grand introduction, the first theme demonstrates intensity at the arrival of the fortissimo $\mathrm{G}$ minor chord. The first theme's motive is a descending forward-motion motive set in the right hand and accompanied by wide arpeggiated texture in the left hand (see example 4.4.2). This theme 1 is reiterated three times. Each time it concludes in a different way. As a result, the musical phrase structure is 4 (the basic theme) $+10+10$ measures (each with extensions). Theme 1 concludes in E-flat minor.

Example 4.4.2: Sonata in G minor "Allegro Vivace e Passionate" ( $1^{\text {st }}$ movement): first theme (mm. 7-10)

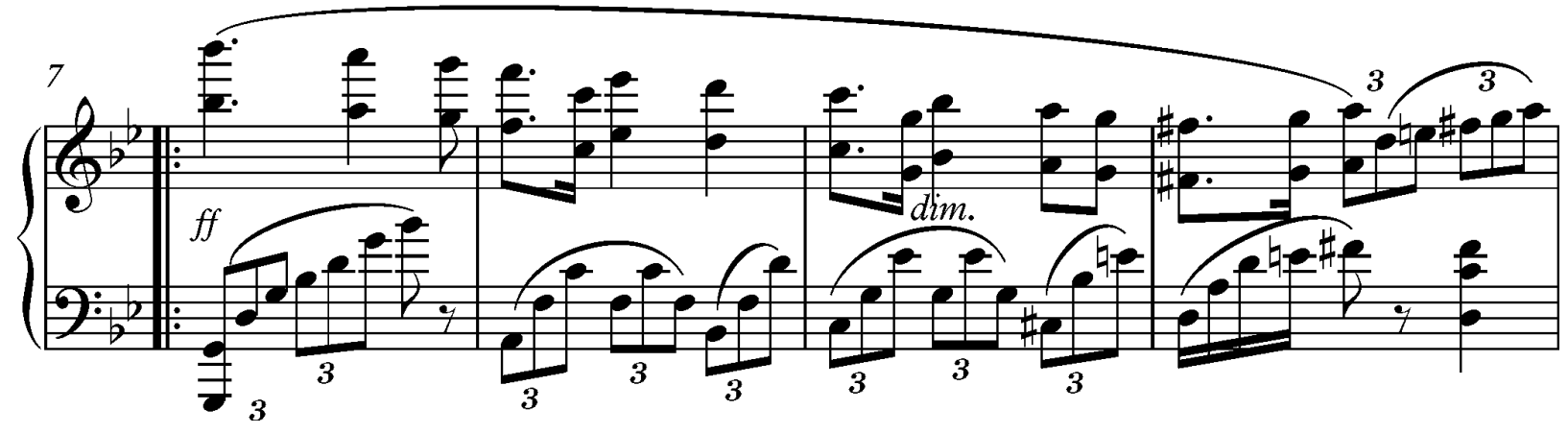

The transitional passage at $\mathrm{m} .31$ is in a duple against triple rhythm. This creates a fast moving feel with rhythmic instability (see example 4.4.3). In addition the composer indicates “animato." This quiet transition (also marked pianissimo) leads to the mood of the second theme which is more gentle, dreamy and lyrical compared to the first theme. 
Example 4.4.3: Sonata in G minor "Allegro Vivace e Passionate"( $1{ }^{\text {st }}$ movement): transitional material (mm. 31-35)

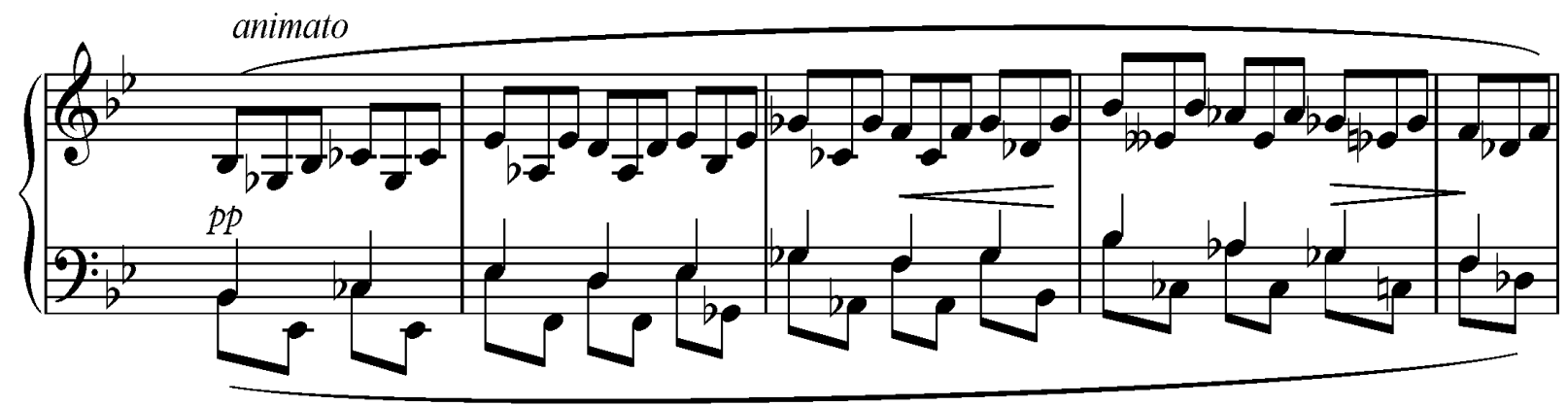

The second theme is in the key of B-flat Major (the relative major of $\mathrm{G}$ minor). However, at the beginning of the theme, the tonality is vague. Tonality is finally established with the B-flat chord in measure 58. There is a definite contrast between the themes. This lyrical second theme texture becomes simpler and lighter (see example 4.4.4).

Example 4.4.4: Sonata in G minor "Allegro Vivace e Passionate" ( $1^{\text {st }}$ movement): second theme (mm. 55-62)
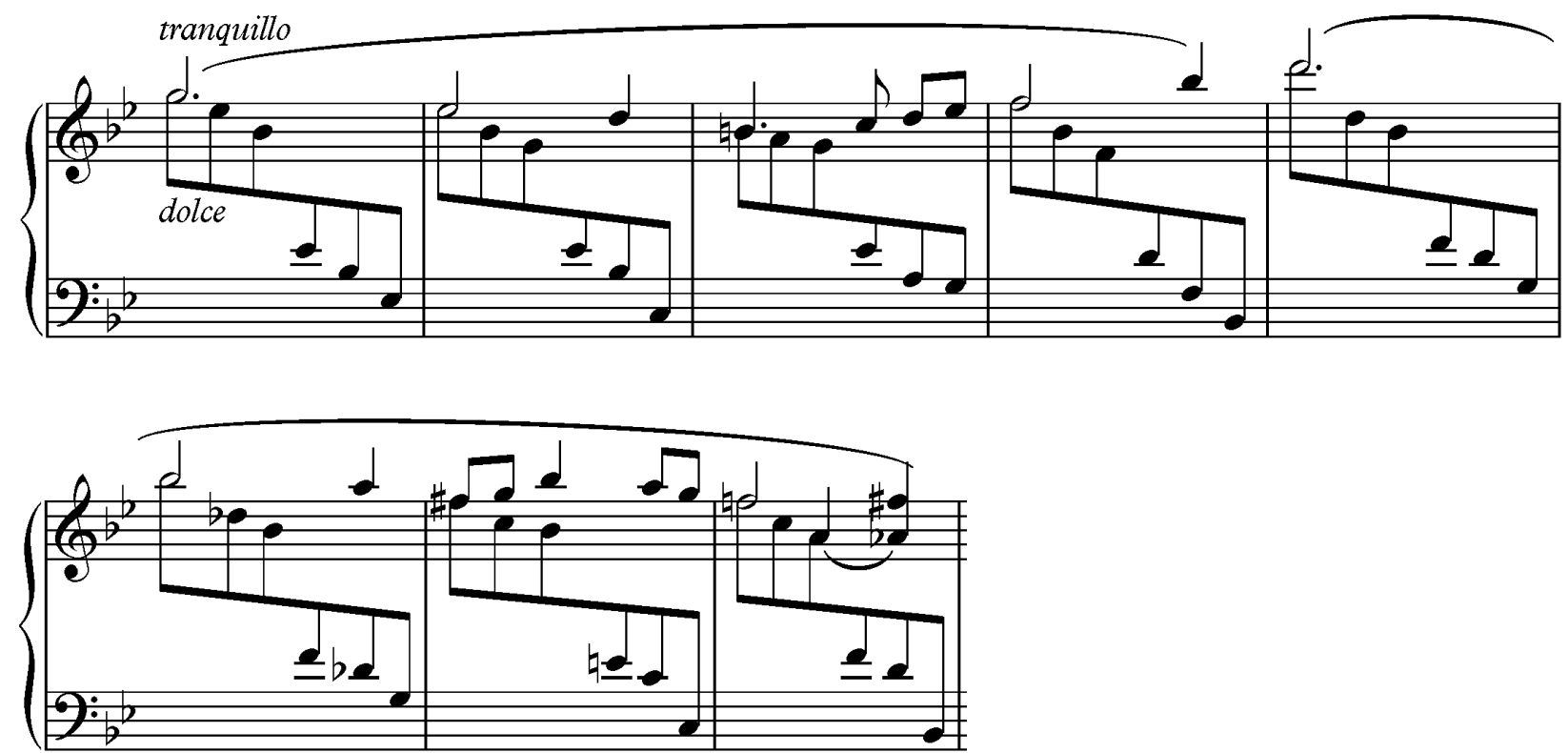

The closing theme begins in measure.79 still in B-flat Major. The melody is in the tenor accompanied by right hand eighth notes marked molto tranquillo. The harmony alternates between B-flat Major and E-flat minor (a $5^{\text {th }}$ apart) (see example 4.4.5). 
Example 4.4.5: Sonata in G minor "Allegro Vivace e Passionate" ( $1^{\text {st }}$ movement): Closing theme (mm. 79-82)

molto tranquillo

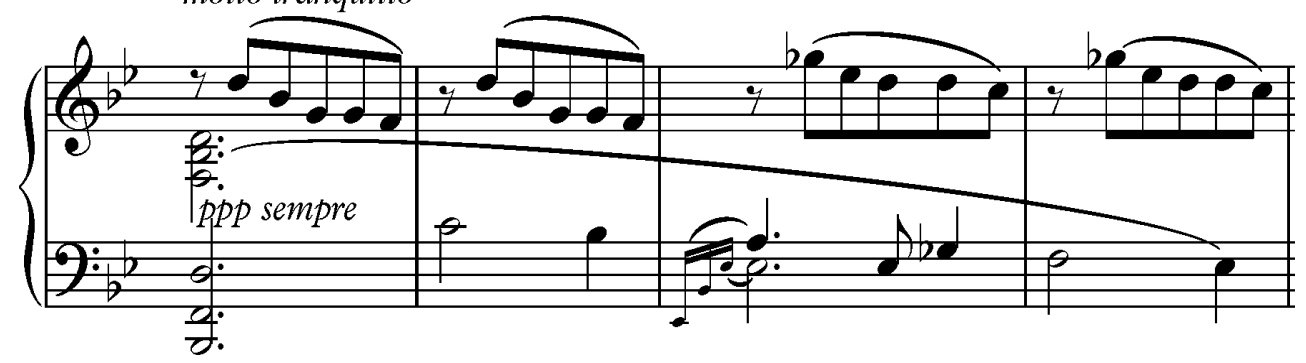

The Exposition concludes with a six measures phrase similar to the opening introduction, now in the dominant key (see example 4.4.6).

Example 4.4.6: Sonata in G minor "Allegro Vivace e Passionate" ( $1{ }^{\text {st }}$ movement): introductory material (mm. 95-100)

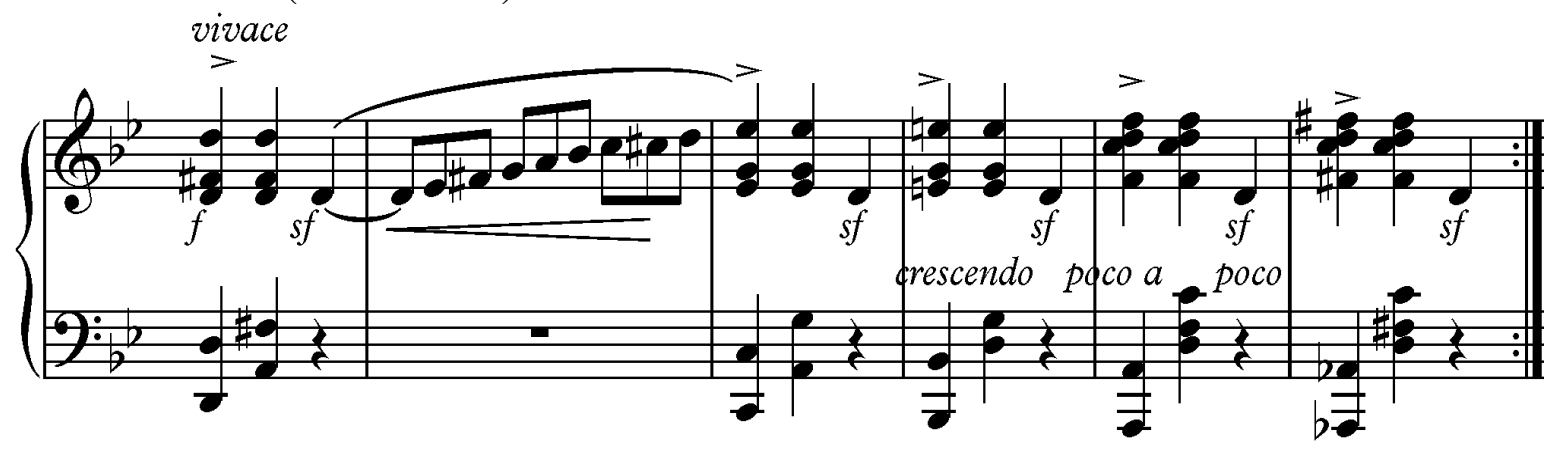

After the Exposition is repeated, the development section opens with the introductory material starting on a G Major chord. The following harmonic progression leads into the key of C minor in $\mathrm{m} .107$. The Development section uses materials from the Exposition including the introduction, transition, and theme 1 in many different keys. It almost sounds like an improvisation with frequent modulations. The second theme is not used in this section, but a theme which closely resembles the head of the first theme is introduced in m. 140 and begins in the key of F minor (see example 4.4.7). 
Example 4.4.7: Sonata in G minor "Allegro Vivace e Passionate" ( $1^{\text {st }}$ movement): Modified first theme (mm.140-143) in the development section.

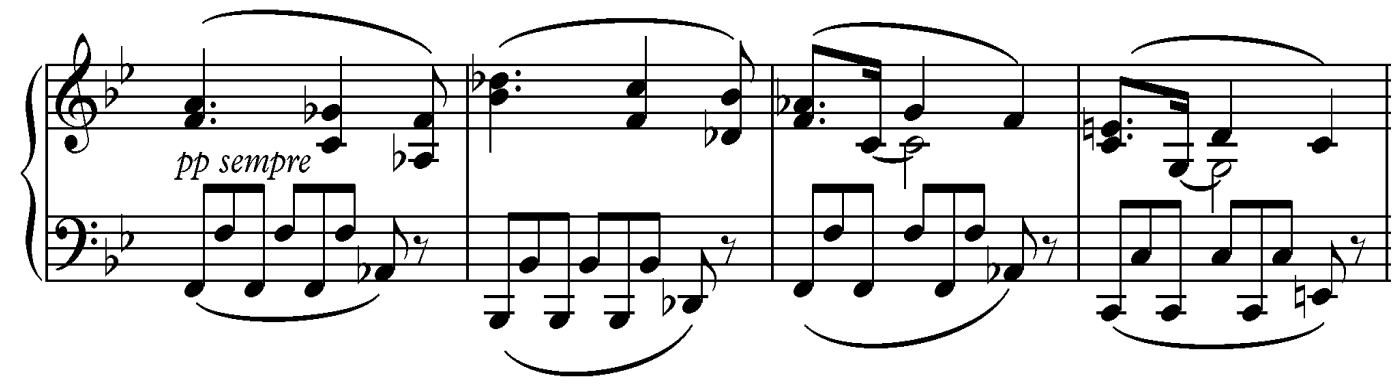

The theme is developed, altered and modulated through a number of key areas. The

Development concludes with the introductory material in the dominant key (m. 190) and leads back to the Recapitulation section in $\mathrm{m} .198$.

In the Recapitulation, the themes are presented in the same order as in the Exposition. The first theme returns in the home key of G minor. Following the transition, as in the Exposition, Theme 2 returns in $\mathrm{m}$. 244. Surprisingly, it is in the parallel key of G Major. The closing theme returns in m. 268 in G Major and the harmony alternates between G Major and C minor ( $5^{\text {th }}$ apart). The transitional material from the Exposition returns in $\mathrm{m} .290$, this time with an extended dominant pedal point. The pedal point extends from m. 290 until the arrival of the coda in $\mathrm{m}$. 306, in G minor. The movement concludes passionately with the coda (marked vivacissimo), which is based on material from the first theme.

The second Movement: Romanza, Andante Quasi Adagio

This slow movement is written in A-B-A form and in the key of B-flat Major, the relative key of G minor. Stennhammar indicated "Romanza" which suggests an affectionate and expressive interpretation. This movement consists of two sections showing two distinct accompaniments. This provides different atmospheres while the melodious right hand line remains lyrical. According to Johan Frost's dissertation, "Bo Wallner describes the second movement as a "Chopin Nocturne in a Nordic tone:" (a quote from the massive Stenhammar 
biography books). ${ }^{41}$ Johan Frost also stated that it is hard to relate the movement to anything Swedish because it was not an established style in his music at this time. A brief analysis of the movement is presented in the table below:

\begin{tabular}{|l|l|l|}
\hline Theme 1 & Theme 2 & Theme 1 \\
\hline mm. 1-17 & mm. 18-45 & mm. 46-64 \\
B-flat Major & G minor & B-flat Major \\
\hline
\end{tabular}

The first theme is accompanied by eighth-note chords which are used consistently throughout the entire section (see example 4.4.8). The second theme is accompanied by triplet figures. The first theme initially opens with a $\mathrm{G}$ minor chord but at the same time the key of Bflat Major is also suggested.

Example 4.4.8: Sonata in G minor "Romanza, Andante Quasi Adagio": first theme (mm. 1-4).
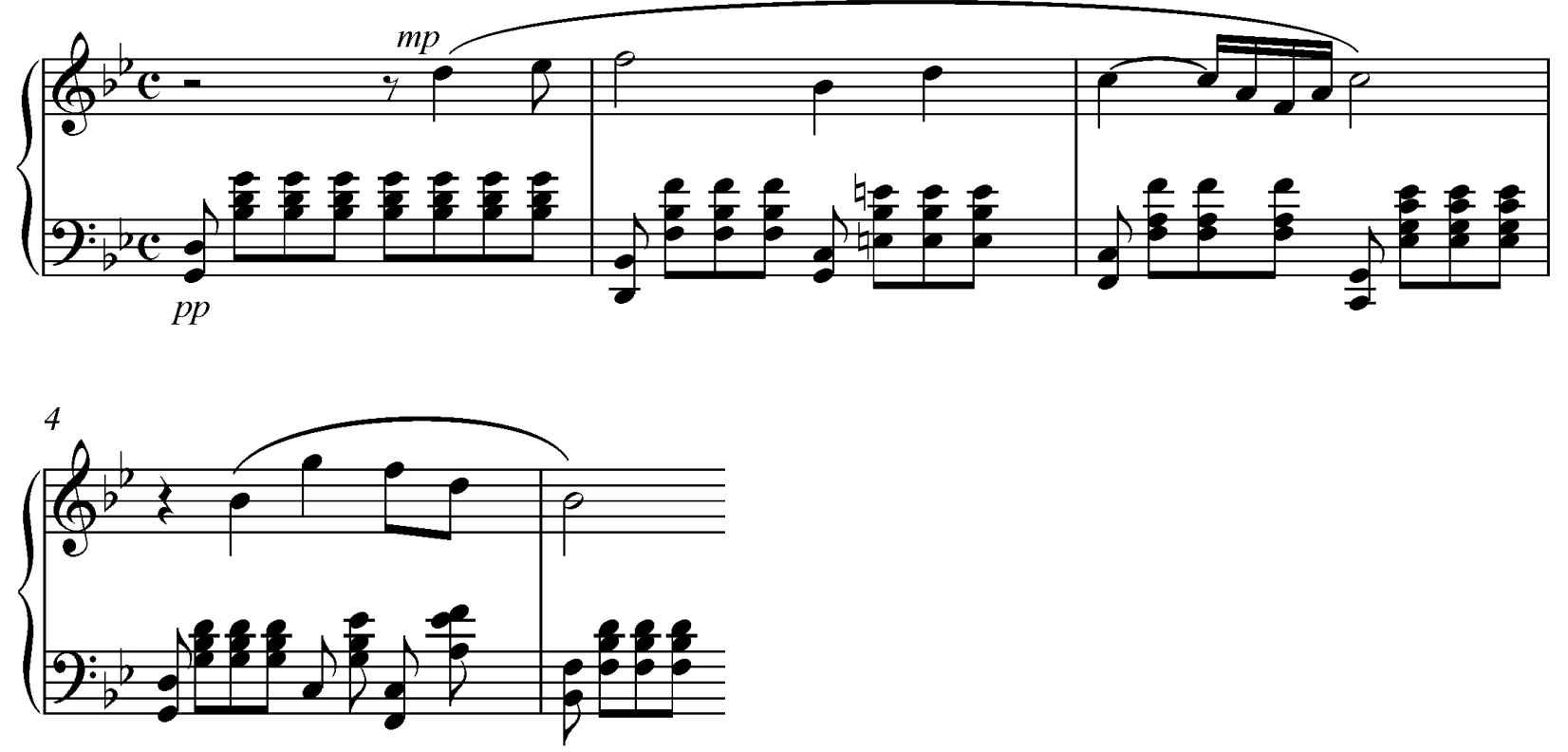

41 Johan Frost, Swedish Piano Music by Stenhammar in the Shadow of Grieg. (Ph.D., Diss: Rice University), 53. 
The second theme appears in what seems to be a modulatory section. It starts in the key of G minor with Dominant "D" pedal point before it modulates via the circle of fifths into different keys (example 4.4.9).

Example 4.4.9: Sonata in G minor "Romanza, Andante Quasi Adagio": second theme (mm. 18-22).

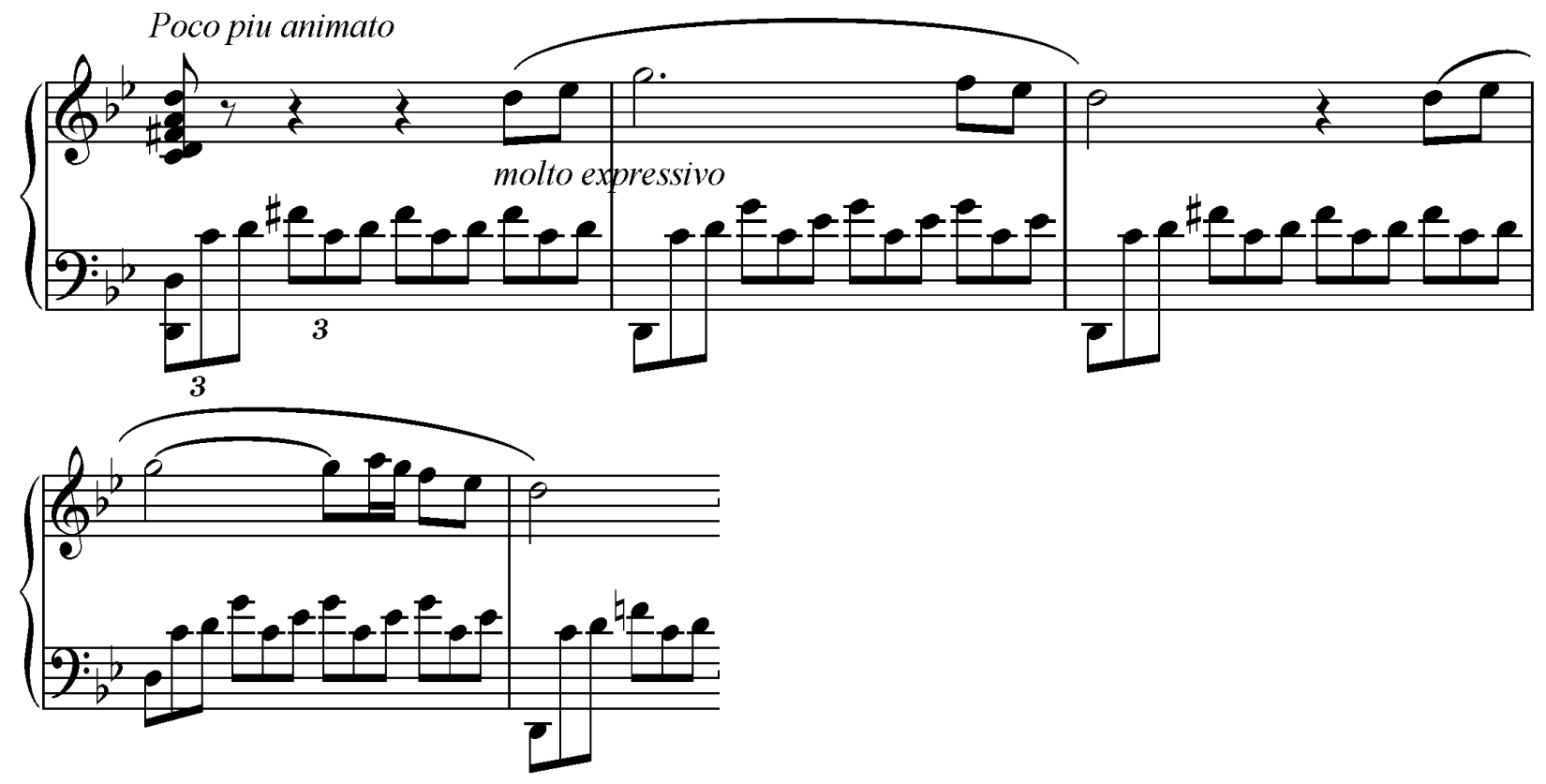

Another similar modulatory passage appears in mm. 39-42 (E-flat- A flat- D flat- G flat- C- F) before returning to the first theme clearly in the key of B-flat in $\mathrm{m} 46$.

The third Movement: Scherzo and Trio.

This movement is a Scherzo and Trio, a typical dance combination similar to Minuet and Trio but much faster. It consists of three sections. A brief analysis of the movement is presented in the table below:

\begin{tabular}{|l|l|l|}
\hline Scherzo & Trio & Scherzo \\
\hline $\begin{array}{l}\text { D minor } \\
\text { mm.1- } 68\end{array}$ & D Major & D minor \\
mm. 69- 132 & mm. 133- 184 \\
\hline
\end{tabular}

The scherzo is in the key of D minor but with a strong impact on the dominant triad of $\mathrm{A}$ Major. It is in rapid triple time. The first theme is based on the $\bullet \cdot \downarrow \cdot \downarrow$ : a short staccato motive 
over the bar line. This rhythmic pattern suggests a folk-dance and humoresque attitude (see example 4.4.10).

Example 4.4.10: Sonata in G minor "Scherzo"(third movement): Scherzo theme (mm. 1-4).

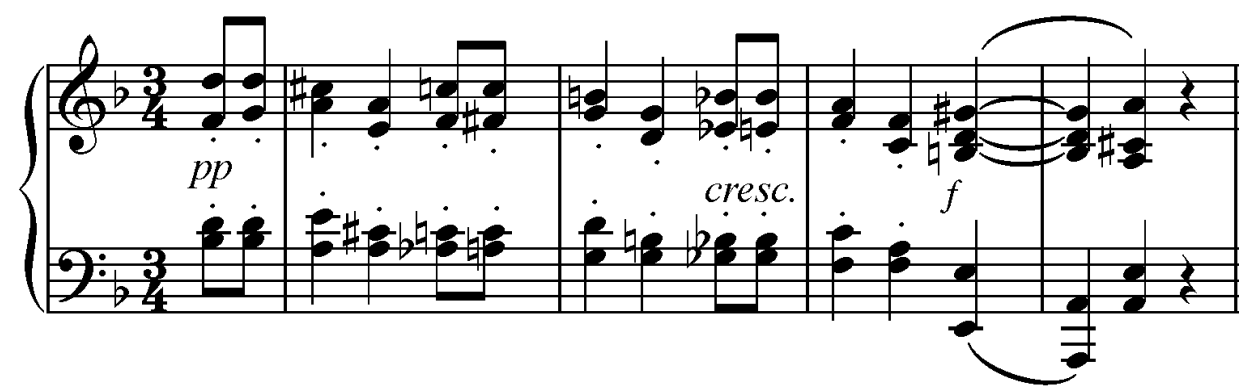

A brief Trio section opens with a quiet lyrical melody line with legato touch as indicated legatissimo. The trio theme is presented in longer note values in contrast to the Scherzo theme and is in the key of D Major (Parallel Key) (see example 4.4.11).

Example 4.4.11: Sonata in G minor "Meno mosso- un pochettino"(third movement): Trio theme (mm. 69-84).
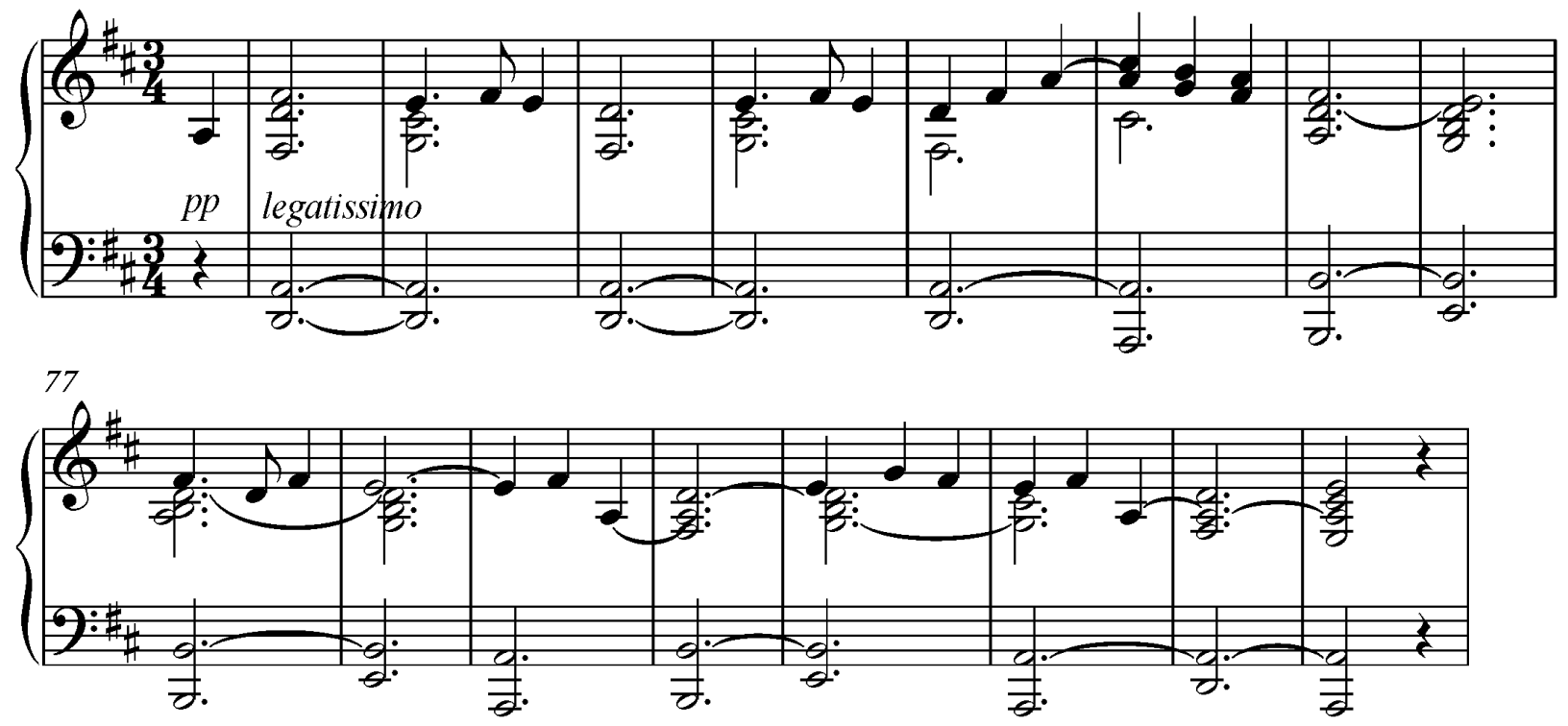

The Scherzo section returns in m. 133 and themes are presented in the same order as in the earlier scherzo section. Stenhammar concludes this movement with a D Major chord (Picardy third), instead of to the minor tonic chord of the home key. 
The fourth Movement: Rondo

This fourth movement is written in a rondo form that also contains elements of sonata form. The first theme always returns in the home key of $\mathrm{G}$ minor. The contrasting themes are presented in relative major key (the second theme in B-flat Major) and a major third apart relationship from the home key (the third theme in E-flat Major). Each theme has distinct characteristics which clearly defines the section. A brief analysis of movement is presented below:

\begin{tabular}{|c|c|c|c|c|}
\hline Theme 1 & Transition & Theme 2 & Theme 1 & Theme 3 \\
\hline $\begin{array}{l}\text { mm. 1-36 } \\
\text { G m }\end{array}$ & $\begin{array}{l}\text { mm. 37-48 } \\
\text { B-flat } \\
\text { Circle of } 5^{\text {th }}\end{array}$ & $\begin{array}{l}\mathrm{mm} .49-76 \\
\text { B-flat Major }\end{array}$ & $\begin{array}{l}\mathrm{mm} .77-110 \\
\mathrm{G} \min \end{array}$ & $\begin{array}{l}\text { mm. 111-162 } \\
\text { E-flat Major }\end{array}$ \\
\hline Theme 1 & Transition & Theme 2 & Theme 3 & Extended Coda \\
\hline $\begin{array}{l}\text { mm. 163-186 } \\
\text { G min }\end{array}$ & $\begin{array}{l}\text { mm. } 187-198 \\
\text { Circle of } 5^{\text {th }}\end{array}$ & $\begin{array}{l}\text { mm. 198-228 } \\
\text { G Major }\end{array}$ & $\begin{array}{l}\text { mm. } 229-250 \\
\text { E-flat Pedal point }\end{array}$ & $\begin{array}{l}\mathrm{mm} .251-330 \\
\mathrm{G} \min \end{array}$ \\
\hline
\end{tabular}

The first theme is presented as a lyrical and expressive melody and is introduced in the tenor voice under a quiet right-hand sixteenth note accompaniment (see example 4.4.12). In measure 11, the lyrical and expressive melody shifts to the soprano line with the same rapid sixteenth note accompaniment.

Example 4.4.12 Sonata in G minor "Rondo. Allegrissimo" (Finale): first theme (mm. 1-10).
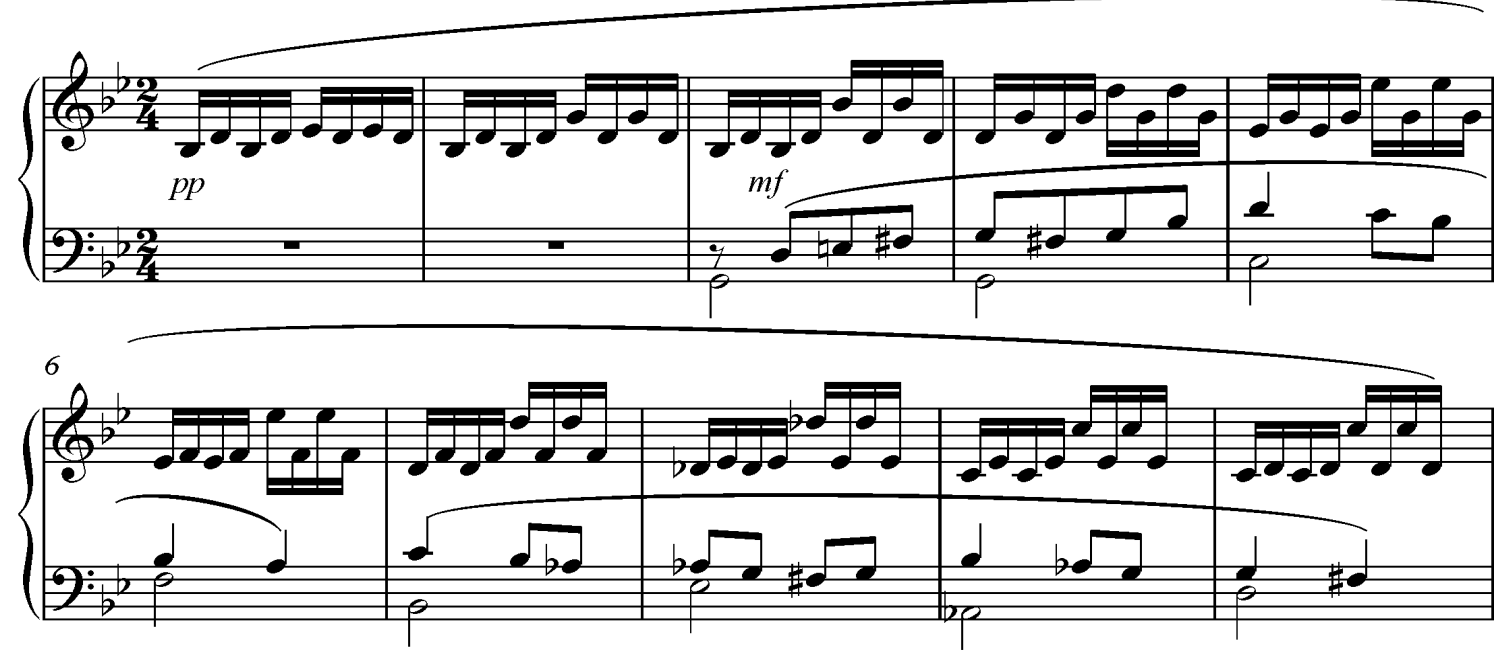
The transition occurs in $\mathrm{m} .37$ in a circle of fifths progression (B-flat, F, C, and G): anticipating the new melodious character of the second theme by modulating to the tonal center of its relative major (key in B-flat Major). This passage is highly chromatic and modulatory, implying different key areas. The texture of second theme is homophonic, with the melodic line in the soprano accompanied by an arpeggiated harmonic progression (see example 4.4.13).

Example 4.4.13: Sonata in G minor "Rondo. Allegrissimo" (Finale): second theme (mm. 49-56)
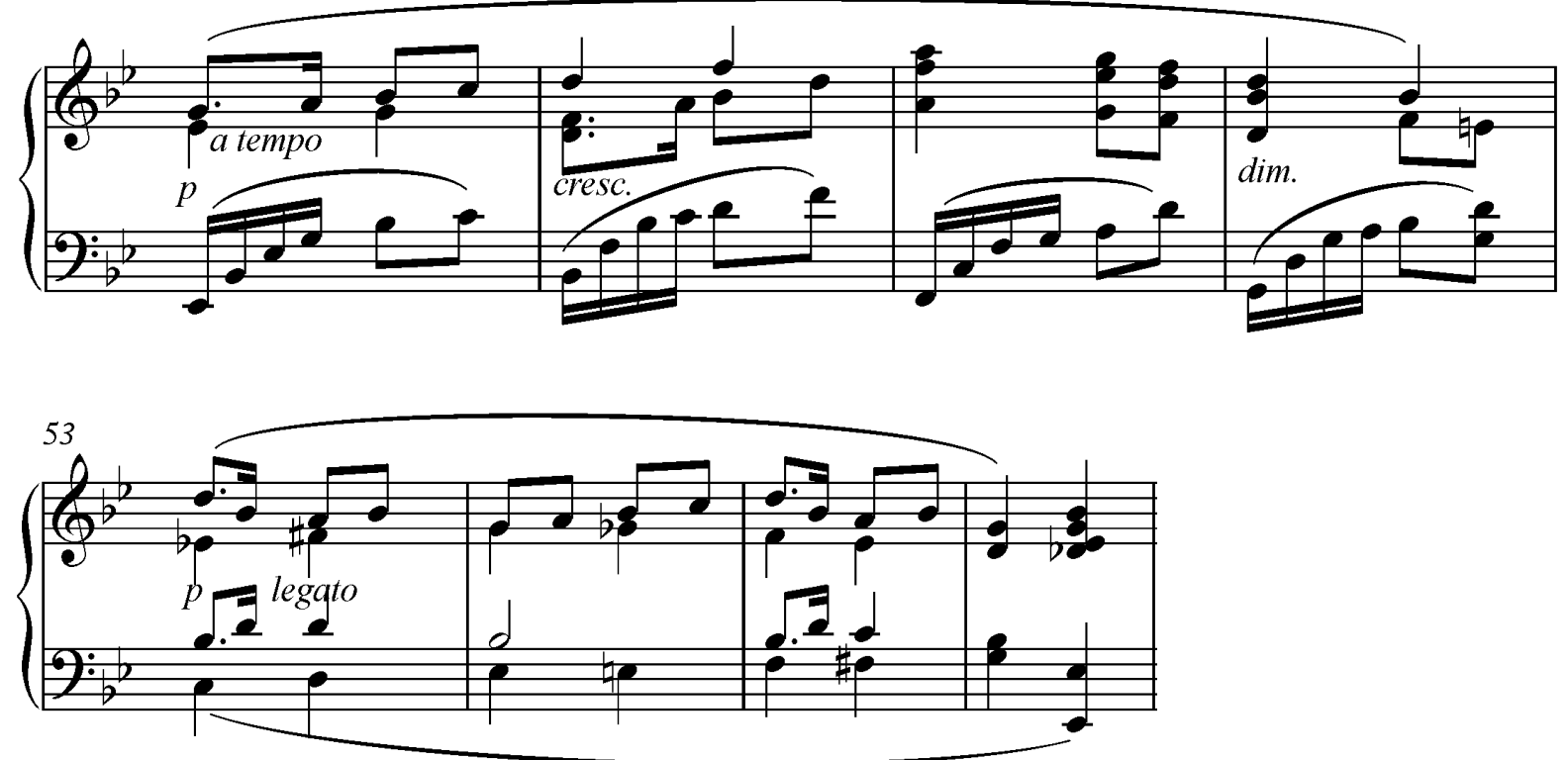

A sudden change of character (from the melody with flowing accompaniment to a dancelike dotted rhythm pattern) creates contrast. The composer expresses this through using a different articulation and varying the harmonic progression. The third theme opens with a B-flat ninth chord of E-flat Major which is a third-relationship key of G minor (see example 4.4.14). The E-flat Major tonality is finally established in $\mathrm{m} .119$. This passage has elements of development: the theme is developed and modulated through a number of key areas before returning to the first theme in $\mathrm{m} .163$. 
Example 4.4.14: Sonata in G minor "Rondo. Allegrissimo" (Finale): third theme (mm. 111-114).

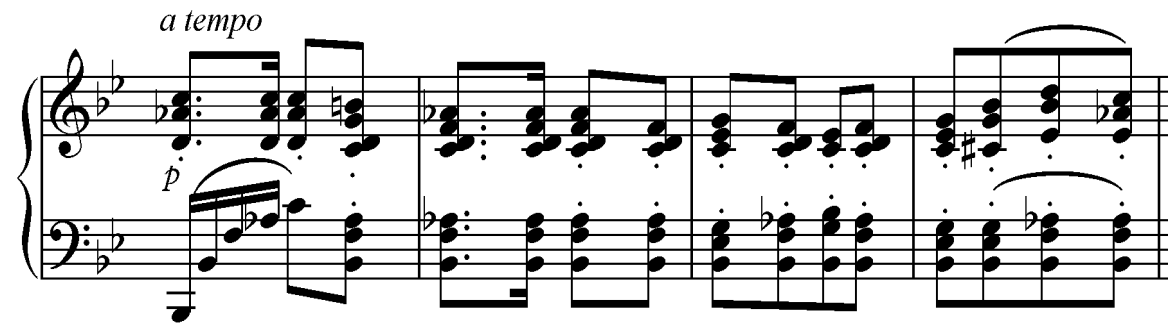

The first theme, transition and the second theme are returned in the same order. However, the second theme now is modulated to the tonal center of G Major (similar to sonata element: to return to the tonic home key). Like the earlier second theme passage, this passage is also modulatory and highly chromatic. Surprisingly, the third theme returns in m. 229 and is presented in longer note value (augmentation). As indicated (Sostenuto), this passage will be sustained in a long E-flat pedal point before proceeding to ma piu animato, a faster Coda.

At the onset of the Coda, the first theme returns fragmented and is followed by a full bar pause in $\mathrm{m} .252,254$, and 257 . The returned first theme is now accompanied by the dominant pedal point until m. 265. In the molto vivace, Stenhammar uses the descending octave in the left hand to return to the home key in the next section. This is followed by an agitated section, based on the first theme material in double notes in the right hand (see example 4.4.15). This doublenote passage is accompanied by an octave bass note followed by broken chord accompanying figure. The sonata concludes with a presto section in $\mathrm{m} .313$ where the first theme material returns for the last time.

Example 4.4.15: Sonata in G minor "Rondo. Allegrissimo" (Finale): Coda (mm. 277- 280). Agitato

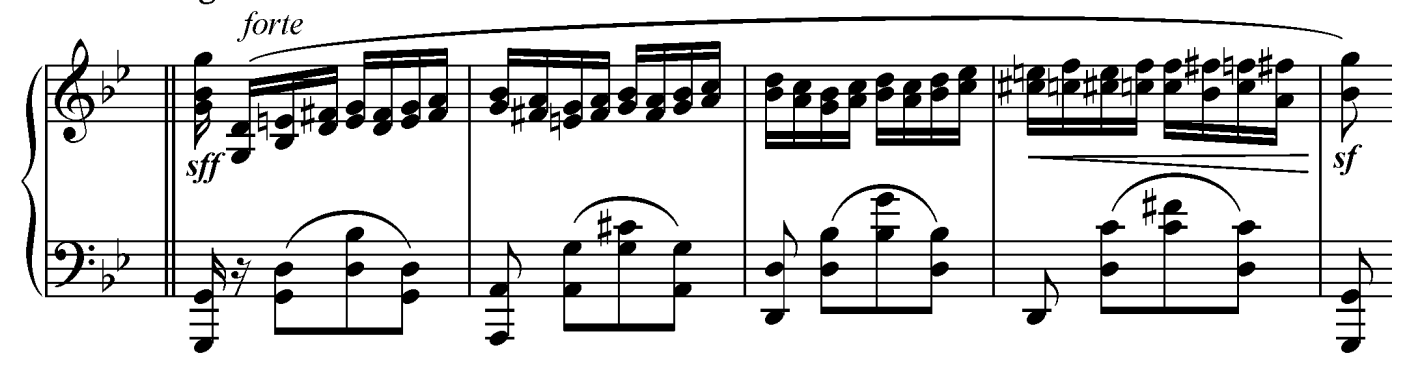




\section{(5) Sonata in A-flat Major, Op. 12}

The Op.12 Piano Sonata was composed in 1895 and was dedicated to his teacher

Andersson. This sonata follows a traditional four-movement plan that consists of: (I) Moderato, quasi Andante; (II) Molto Vivace-Trio; (III) Lento e mesto; and (IV) Allegro. The approximate length of this sonata is about 27 minutes and was the only solo piano sonata that was published during his lifetime.

The first movement: Moderato quasi Andante

This movement is written in Sonata-Allegro form. It starts with a slow 3/4 meter and changes to a slightly faster $4 / 4$ meter. A brief analysis of the movement is presented in the table below.

\begin{tabular}{|c|c|c|}
\hline Exposition & & \\
\hline $\begin{array}{l}\text { Introduction } \\
\text { mm. 1-8 } \\
\text { Key of A-flat Major }\end{array}$ & $\begin{array}{l}\text { Theme } 1 \text { (18 bars) } \\
\text { mm. 9-26 } \\
\text { Key of A-flat Major }\end{array}$ & $\begin{array}{l}\text { Theme } 2 \text { (18 bars) } \\
\text { mm. } 27-44 \\
\text { Key of } \mathrm{C} \text { minor }\end{array}$ \\
\hline
\end{tabular}

\begin{tabular}{|l|l|l|l|}
\hline \multicolumn{2}{|l|}{ Development } & $\|$ & Retransition \\
\hline Material from the Introduction & Theme 1 & mm. 73-85 & Sostenuto \\
mm. 45- 53 & mm. 54- 72 & Ellegro animato & Eajor \\
Tempo I & C Major & \\
Key of C Major &
\end{tabular}

\begin{tabular}{||l|l|l|}
\hline \multicolumn{2}{|l|}{ Recapitulation } & Theme 2 \\
mm. 102-120 & $\begin{array}{l}\text { Introductory material } \\
\text { mm. 121-141 }\end{array}$ \\
Key of A-flat Major & Key of F minor & Key of A-flat Major \\
\hline
\end{tabular}

The sonata opens with a chordal-style slow introduction in $3 / 4$ meter and is in the key of A-flat Major. This eight-measure opening material begins with tonic chord and ends in $\mathrm{m} .8$ with dominant chord which sustains over embellished notes that connect to the following first theme. This opening material will reappear at the onset of each new section. 
Example 4.5.1: Sonata in A-flat Major, Op. 12 "Moderato quasi Andante" ( $1^{\text {st }}$ movement): Opening material (mm. 1-8).

Moderato, quasi Andante.
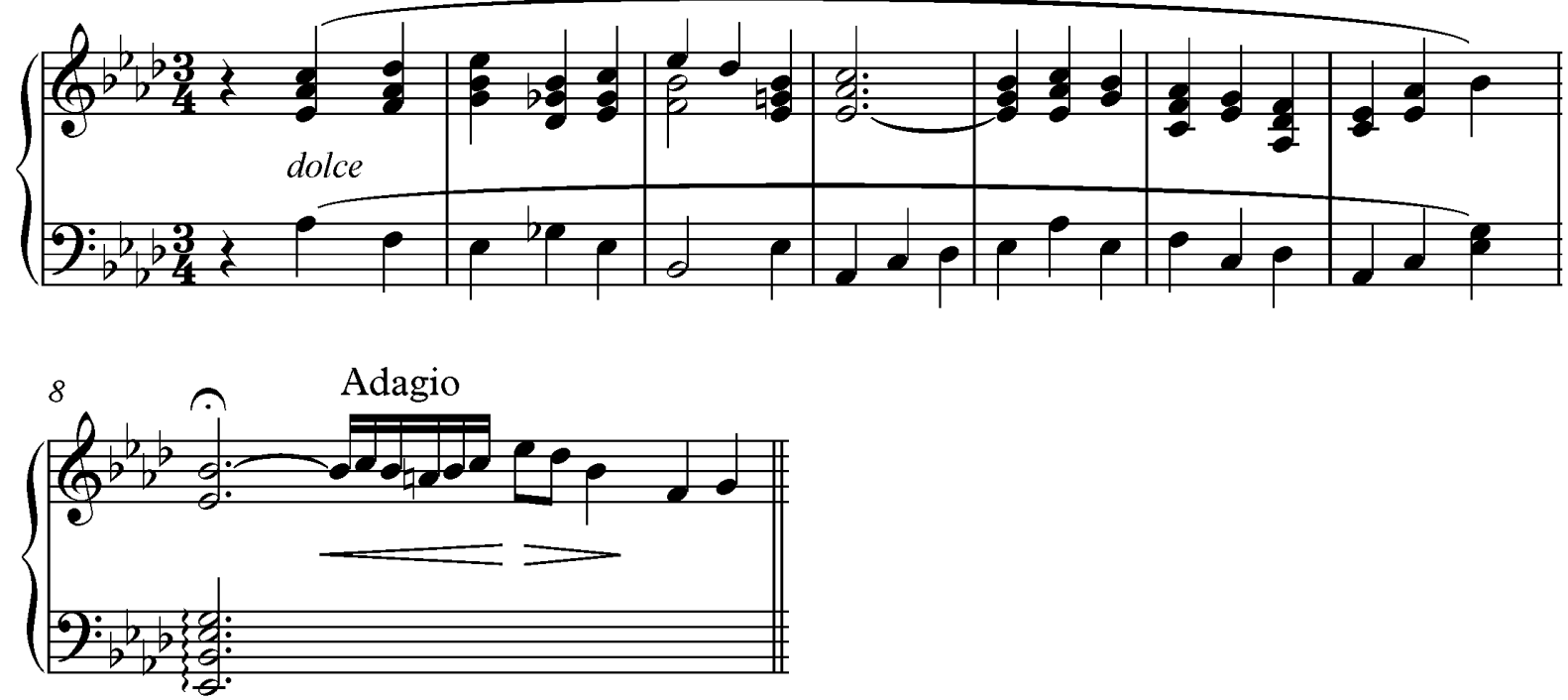

The Exposition consists of two contrasting themes: the first theme in $\mathrm{m} .9$ and the second theme in m. 27. After the slow chordal introduction, the first theme arrives with forward-moving eight notes and is the key of A-flat Major. It is clear that the first theme is in the key of A-flat Major even though the phrase begins with the progression IV $|\mathrm{V}|$ vi $\mid \mathrm{V}$ and tonic finally is confirmed in $\mathrm{m} .13$. The use of suspension and retardation is apparent and they are alternately used to create rich harmonic language.

Example 4.5.2: Sonata in A-flat Major, Op. 12 "Allegretto animato" ( $1^{\text {st }}$ movement): First theme (mm. 9-13)

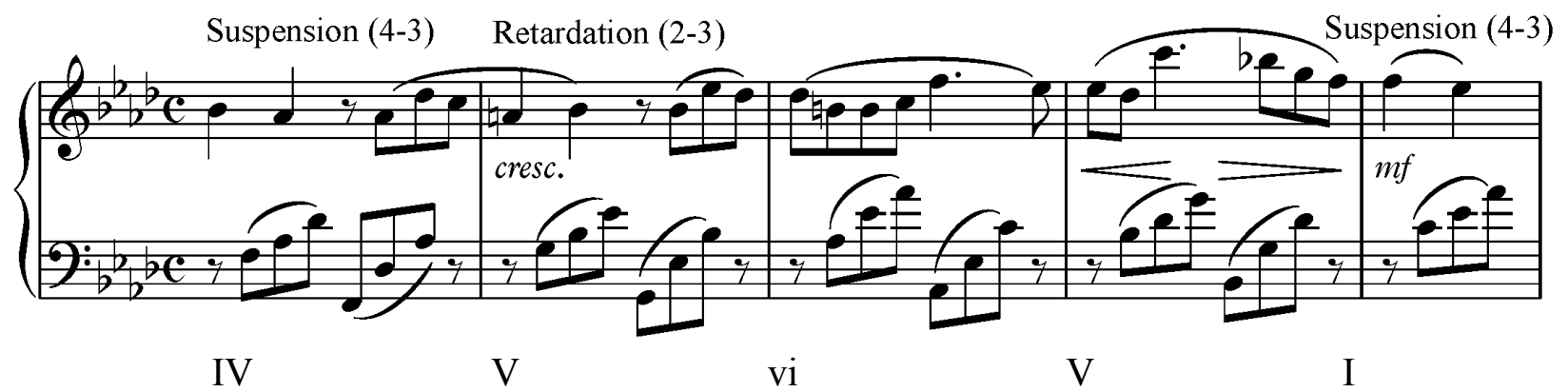

This theme is also presented in different textures: it starts with a 2-voice melody and accompaniment and gradually becomes thicker in full blocked chords. 
Example 4.5.3: Sonata in A-flat Major, Op. 12 "Allegretto animato" ( $1^{\text {st }}$ movement): First theme (mm. 19-22).

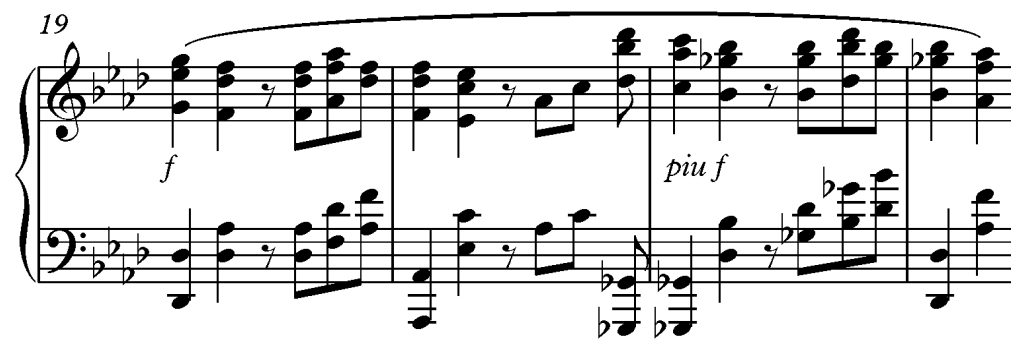

The second theme begins in $\mathrm{m} .27$ and is in the key of $\mathrm{C}$ minor (third relation). This

lyrical and expressive theme (also marked espress.) has a descending right hand melodic line and is accompanied by a $\mathrm{C}$ minor triad with an unusual harmonic change to A-flat.

Example 4.5.4: Sonata in A-flat Major, Op. 12 "Allegretto animato" ( $1^{\text {st }}$ movement): Second theme (mm. 27-30)

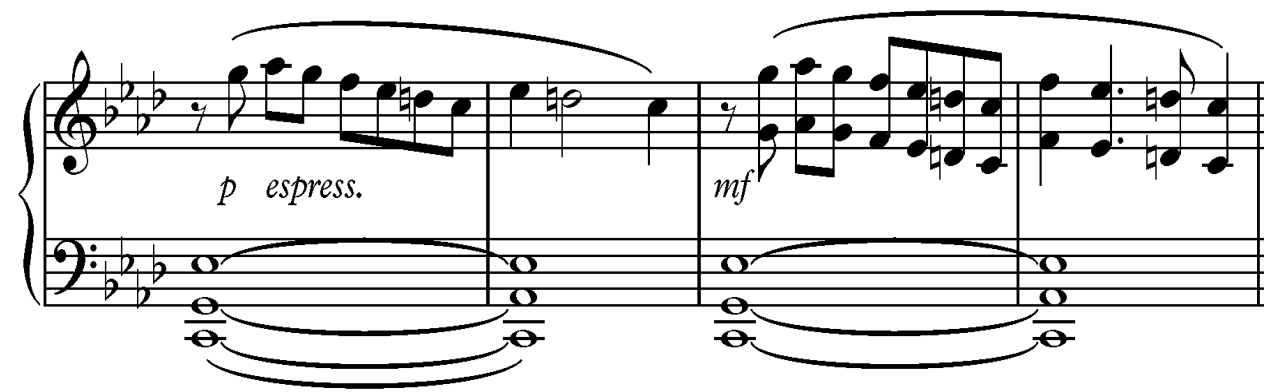

The Exposition concludes with an eight-measure phrase similar to the opening material now in C Major and leading to a development section. In the Development material from the Exposition is used, particularly re-introducing the first theme in the key of C Major. It begins with a 2-voice melody and accompaniment which is gradually modified with frequent modulations, thicker texture, forward-motion eighth notes in the right hand with triplet accompaniment in the left hand. 
Example 4.5.5: Sonata in A-flat Major, Op. 12 "Allegretto animato" ( $1^{\text {st }}$ movement $)$ : Altered first theme

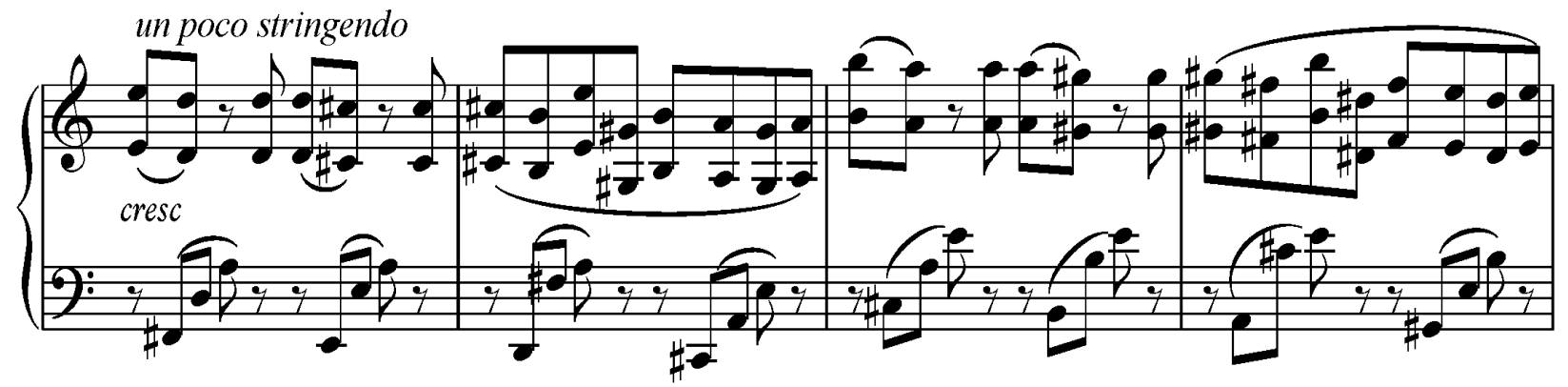

A stable tonality finally arrives in the key of E Major in $\mathrm{m} .73$. The extension (mm. 73-

85) material is derived from the altered first theme motive and is prolonged. The indicated

Sostenuto quasi tempo I refers to the introductory section tempo; it is slower and is in 3/4 meter.

This extension serves as a transition and anticipates the return of the first theme.

Example 4.5.6: Sonata in A-flat Major, Op. 12 "Allegretto animato" ( 1 st movement): Altered first theme

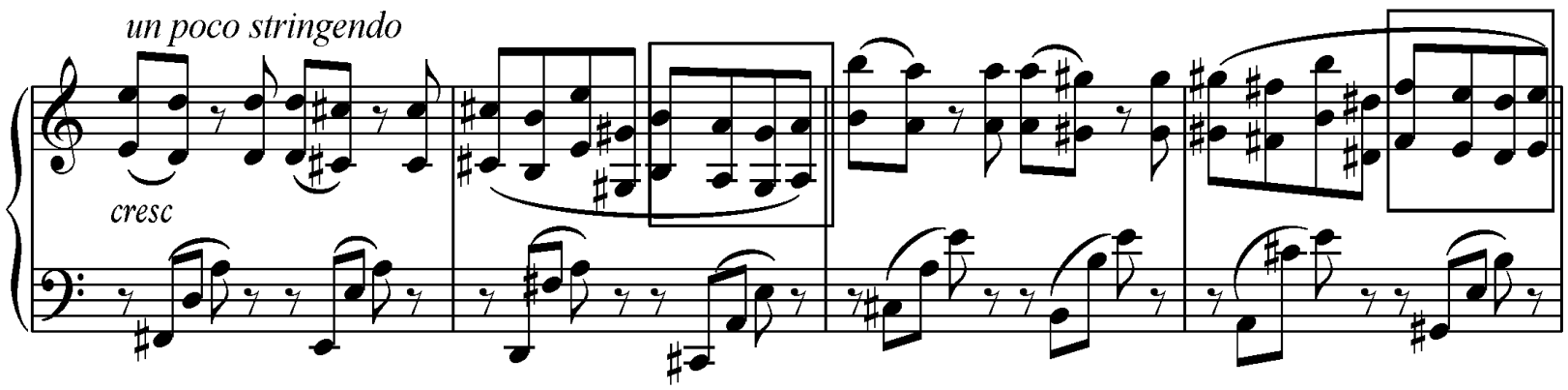

Example 4.5.7: Sonata in A-flat Major, Op. 12 "Allegretto animato" ( 1 st movement): Sostenuto (mm. 73-77)

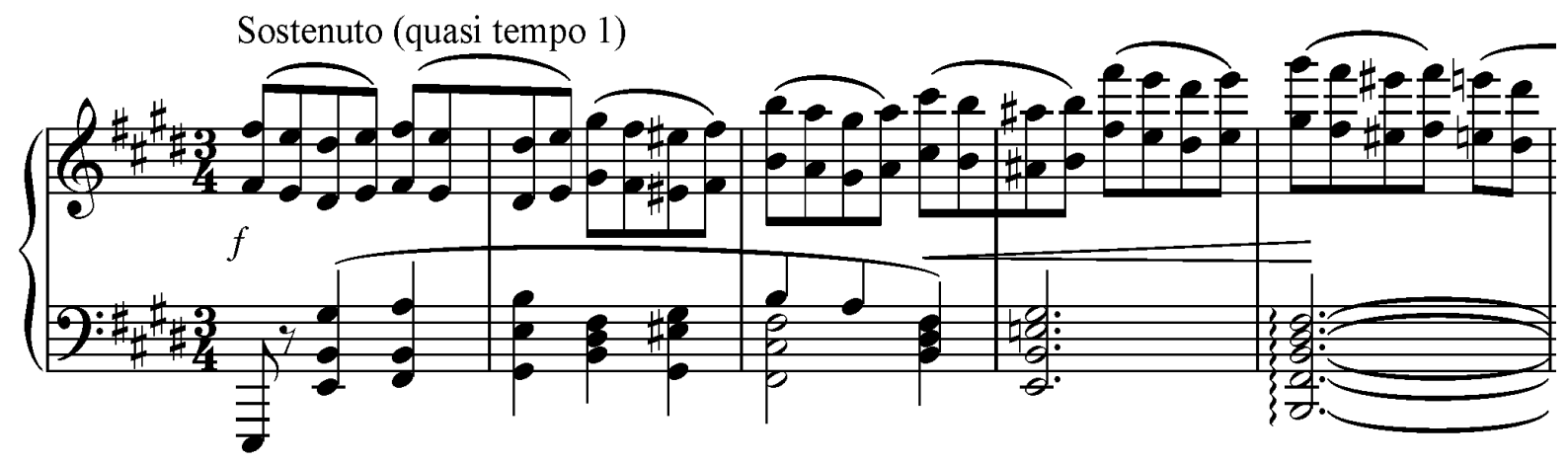


An enharmonic modulation begins in $\mathrm{m} .86$ where the A-sharp begins to be heard as Bflat, highlighting the return of the first theme in the tonic key. In the recapitulation section, previously used materials are re-introduced. The first theme is in the home key, whereas the second theme is in the relative minor key. To conclude this movement, the opening introductory material is reiterated twice: the first time (mm. 121-128) in the key of A-flat and the second time (mm. 129-139) in the relative minor. The tonality is finally resolved to A-flat Major in the last two measures (mm.140-141). The chord progression of ii | I 6/4| IV | V | I confirms it and concludes the ending in the home key.

The second movement: Molto Vivace and Trio.

This movement is written in ternary form. It starts with Molto Vivace 4/4 meter and changes to the slightly faster Trio (presto) 3/4 meter. A brief analysis of the movement is presented in the table below.

\begin{tabular}{|l|l|l|}
\hline \multicolumn{3}{|l|}{ A Section: Molto Vivace } \\
\hline$\|:$ Theme 1 $\quad$ 1. & Theme 2 & Theme 1 \\
mm. 1-37 & mm. 38- 56 & mm. 57-92 \\
C Major & modulatory & C Major \\
\hline
\end{tabular}

\begin{tabular}{|l|l|l|}
\hline B Section: Trio (Presto) \\
\hline $\begin{array}{l}\|: \text { Theme 1 } \sqrt{1 .} \\
\text { mm. 93- } 116\end{array}$ & Theme 2 & Theme 1: then return to A section \\
C minor & & $\begin{array}{l}\text { mm. 175-196 } \\
\text { C minor }\end{array}$ \\
\hline
\end{tabular}

A Section
(return to the A section and finish at the al Fine marked m. 92 without repeat and then
straight to coda).

\begin{tabular}{|l|l|}
\hline \multicolumn{2}{|l|}{ Coda (combination material from A and B sections) } \\
\hline Theme 1 from Trio & Theme 1 from Molto Vivace \\
mm. 198-217 & mm. 218-242 \\
C minor & C Major. \\
\hline
\end{tabular}

The Molto Vivace movement takes a place of scherzo and is in rapid 4/4 meter. The A section consists of two contrasting themes: the first theme has a descending motive and a dotted 
rhythm; the second theme (mm. 38-56) opens with canon and gradually becomes chordal. The first theme in this section opens with descending scales in F minor and the tonality eventually resolves to the designated key in m. 4 (C Major) with the long-short dotted rhythm pattern delayed arrival of the tonic chord through the progression IV $|\mathrm{V}| \mathrm{I}$.

Example 4.5.8: Sonata in A-flat Major, Op. 12 "Molto vivace" ( $2^{\text {nd }}$ movement $)$ : first theme (mm. 1- 7)

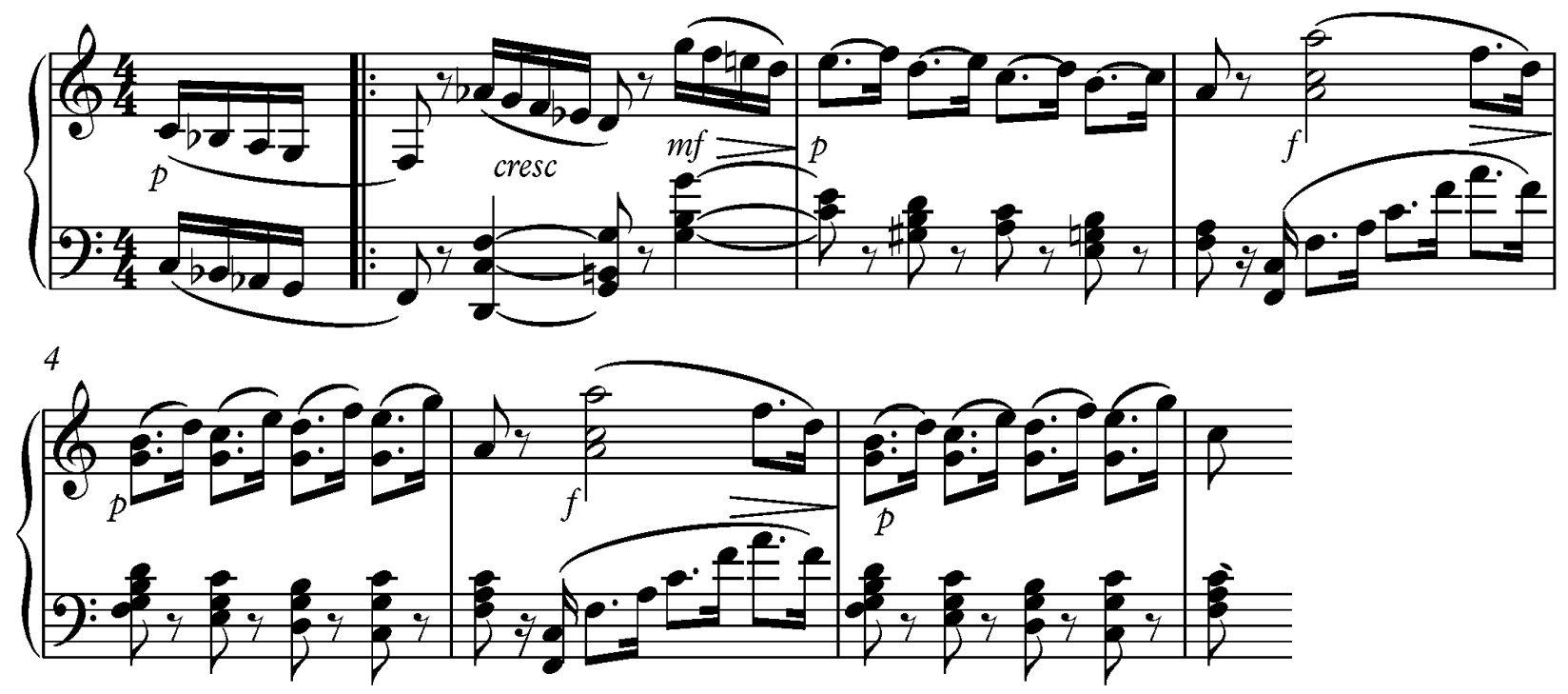

To vary the rhythmic motive (the long-short dotted rhythm) is now presented in a opposite manner (the short-long rhythm) even though aurally, it will sound similar to the earlier motive (see example 4.5.9).

Example 4.5.9: Sonata in A-flat Major, Op. 12 "Molto Vivace" ( $2^{\text {nd }}$ movement): $m .17$.

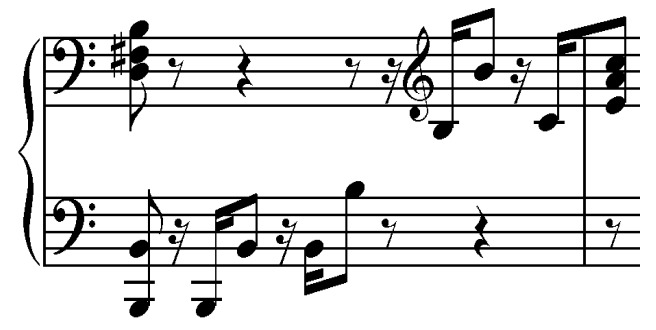


The second theme of the Molto Vivace section is in imitation and is modulatory (see example 4.5.10).

Example 4.5.10: Sonata in A-flat Major, Op. 12 "Molto Vivace" $2^{\text {nd }}$ movement: $2^{\text {nd }}$ theme (mm.37-43).
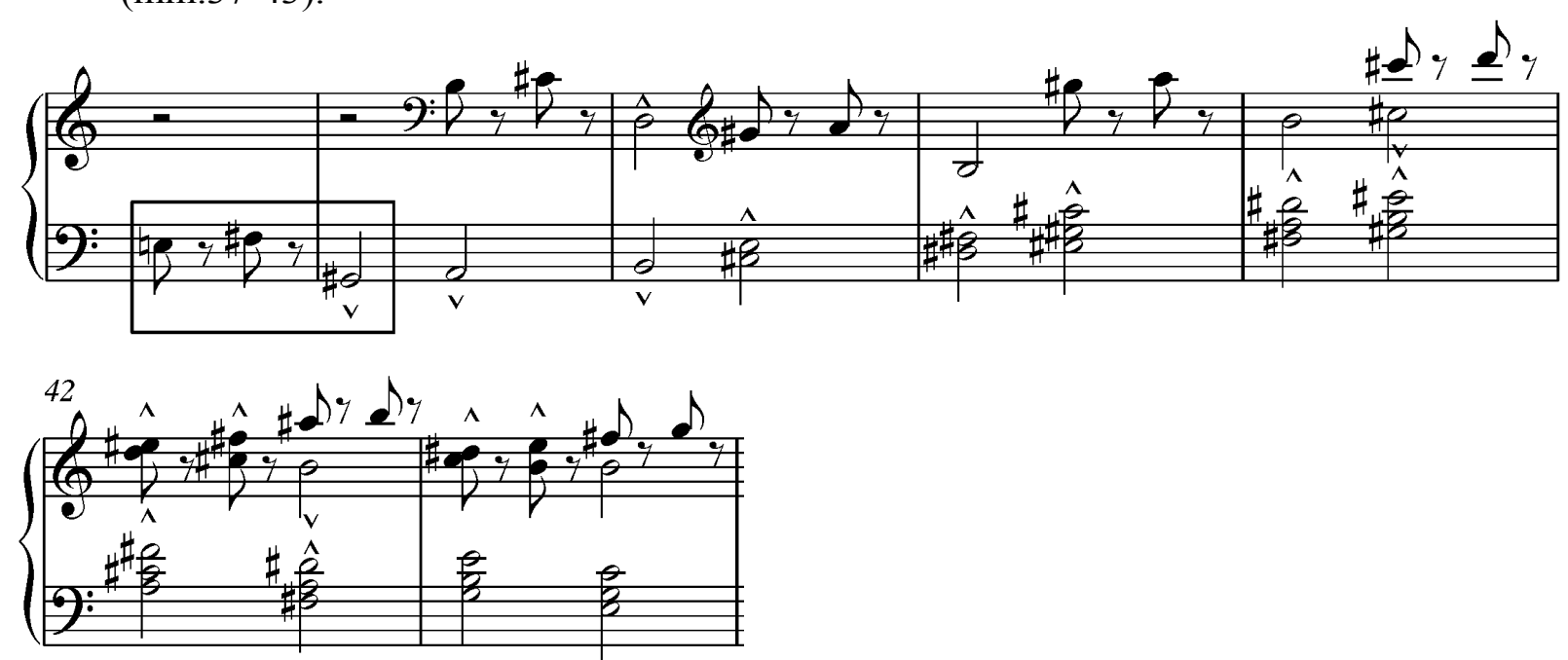

As a contrasting section to the Molto Vivace, The first theme of the Trio section is presented in the key of $\mathrm{C}$ minor and is homophonic (see example 4.5.11).

Example 4.5.11: Sonata in A-flat Major Op. 12 "Trio" second movement: first theme (mm. 97-105).
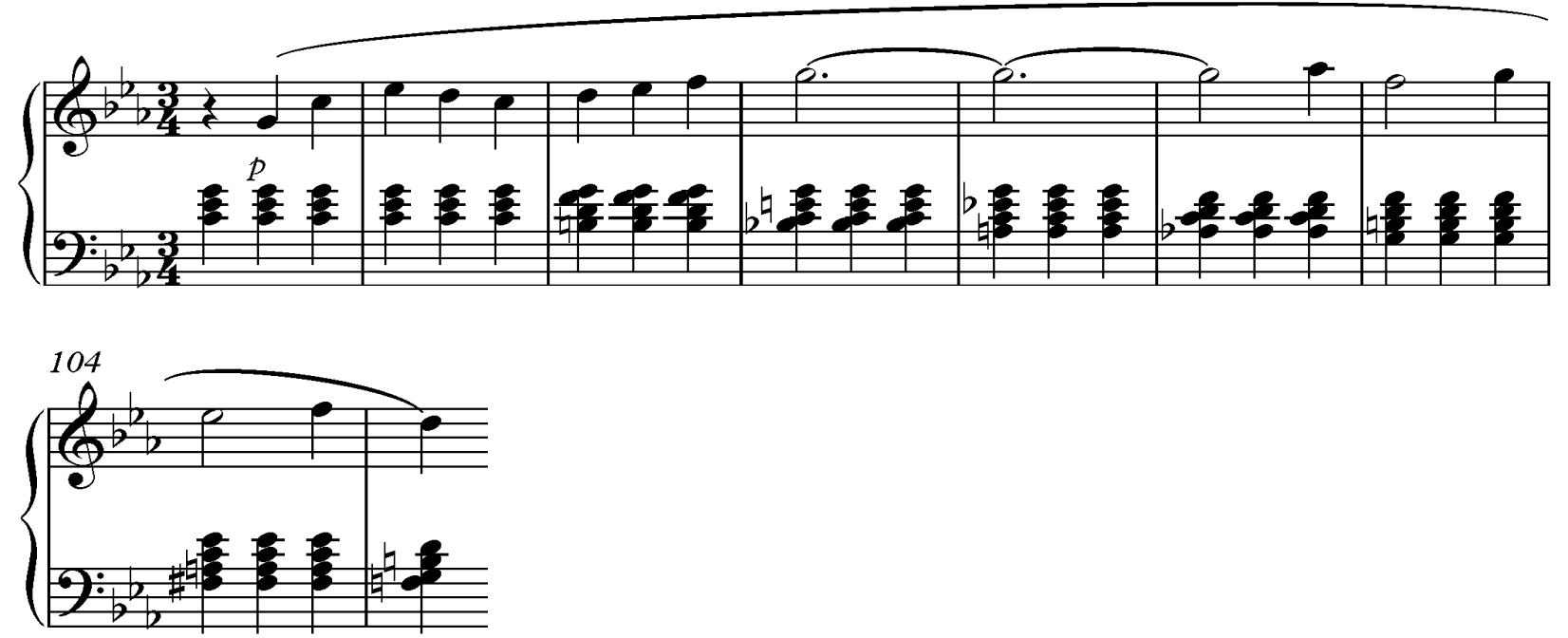
The second theme of the Trio is still in the key of $\mathrm{C}$ minor and is in parallel octaves.

Example 4.5.12: Sonata in A-flat Major Op. 12 "Trio" second movement: (mm. 117-214).

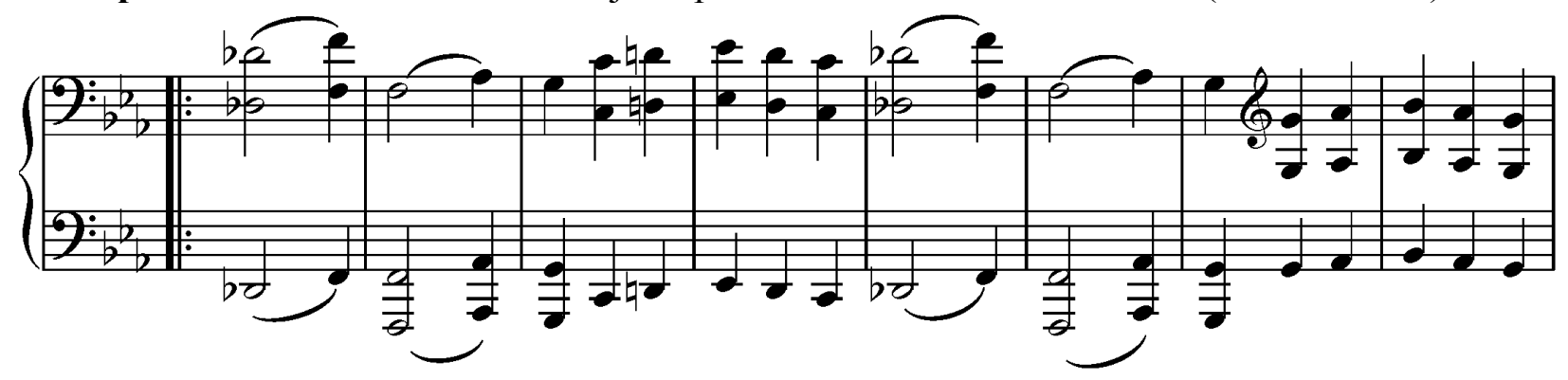

The third movement: Lento e mesto

This movement is a series of modulatory phrases. It starts with a slow $3 / 4$ meter and is in the key of F minor although it is very vague and chromatic. A brief analysis of the movement is presented in the table below.

\begin{tabular}{|l|l|}
\hline A theme & Transition \\
mm. 1- 25 & mm. 26- 47 \\
F minor----G flat major & Modulatory passage \\
\hline
\end{tabular}

This slow movement opens with a full-chord texture with the melody line on the top voice. The theme is reiterated three times: the second time is in the same texture as the first appearance. The third time, Stenhammar changed the chordal texture to imitative texture between the soprano and the tenor voice.

Example 4.5.13: Sonata in A-flat Major Op. 12 "Lento e mesto": A theme (mm.1-8).

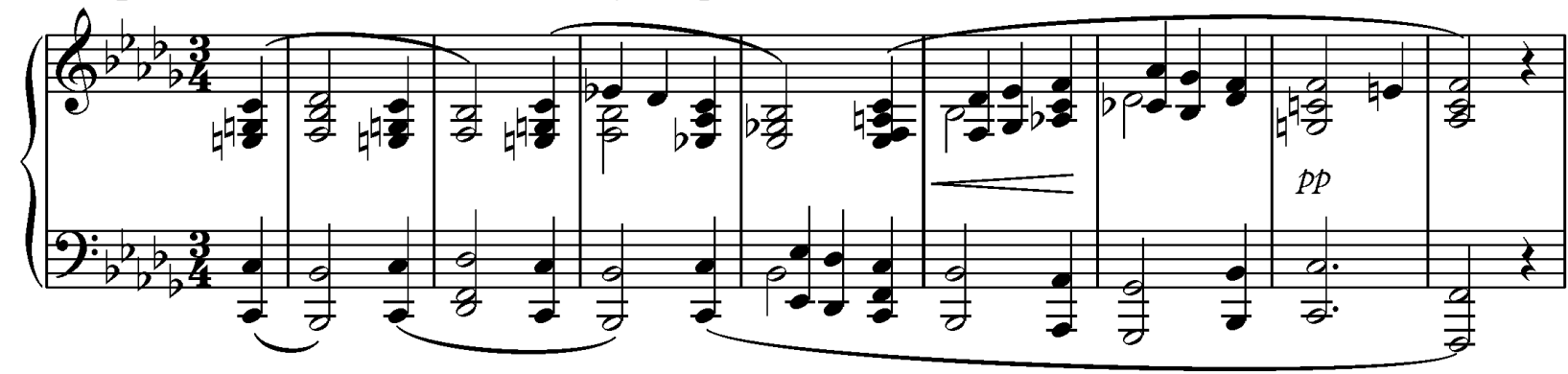


Example 4.5.14: Sonata in A-flat Major Op. 12 "Lento e mesto": imitation between the soprano and tenor voice

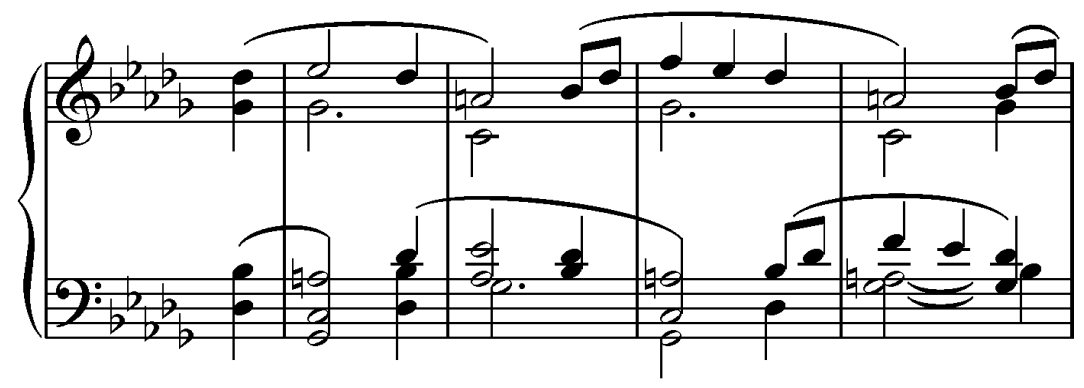

The transition at the end of this movement serves as an attaca to the finale movement by prolonging the F Major minor ninth chord.

Example 4.5.15: Sonata in A-flat Major Op. 12 "Lento e mesto": mm. 46-47.

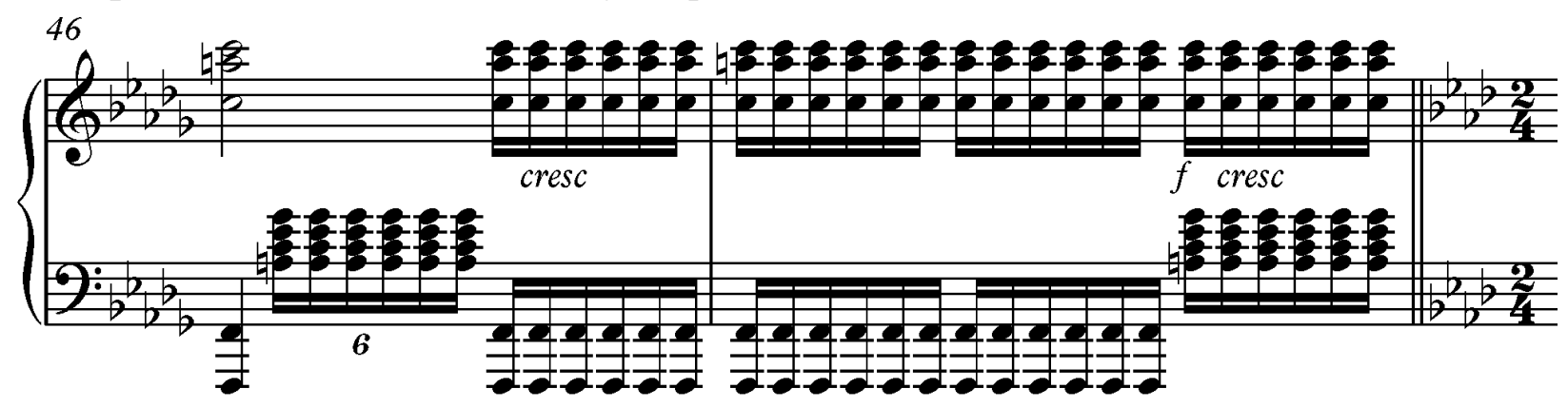

The fourth movement: Allegro

This movement is written in rondo-like form: the materials are re-introduced and altered even though the movement does not fit into a traditional rondo form. The overall structure is in six sections. A brief analysis of the movement is presented in the table below

\begin{tabular}{|l|l|l|l|l|l|}
\hline A section & B section & C section & A section & C section & B section + Coda \\
mm. 1-53 & mm. 54-140 & mm. 141-203 & mm. 204-299 & mm.300-348 & mm. 349- 414 \\
A-flat & A-flat-E flat & BM- CM & A-flat (C) & A-flat & A-flat \\
\hline
\end{tabular}

The A section begins with a continuation of $\mathrm{F}$ Major minor ninth chord in fortissimo followed by a descending motive that keeps modulating. The tonality at the beginning of this movement is vague. It is vague until the first theme arrives in $\mathrm{m} .16$ through the progression IV| $\mathrm{V}$ only then the tonic chord of A-flat major is confirmed in m. 17 (see example 4.5.16). 
This theme is developed at every appearance through different modulations and textures.

Example 4.5.16: Sonata in A-flat Major Op. 12 "Allegro"(fourth movement): A section theme

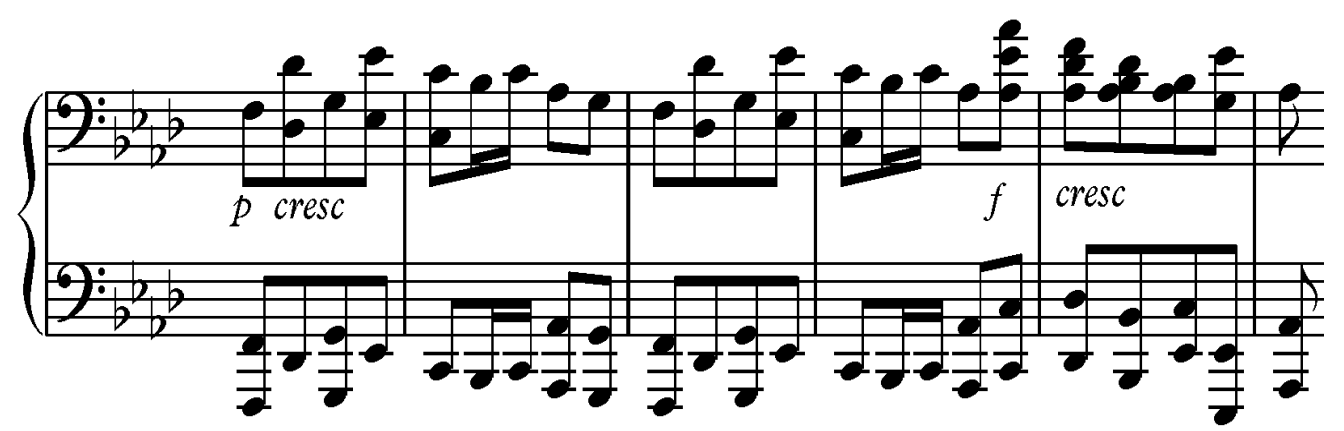

The A-section theme continues with another motive that is presented on the tonic and dominant chords (see example 4.5.17).

Example 4.5.17: Sonata in A-flat Major Op. 12 "Allegro" (fourth movement): A section themeanother motive (mm.21-25).

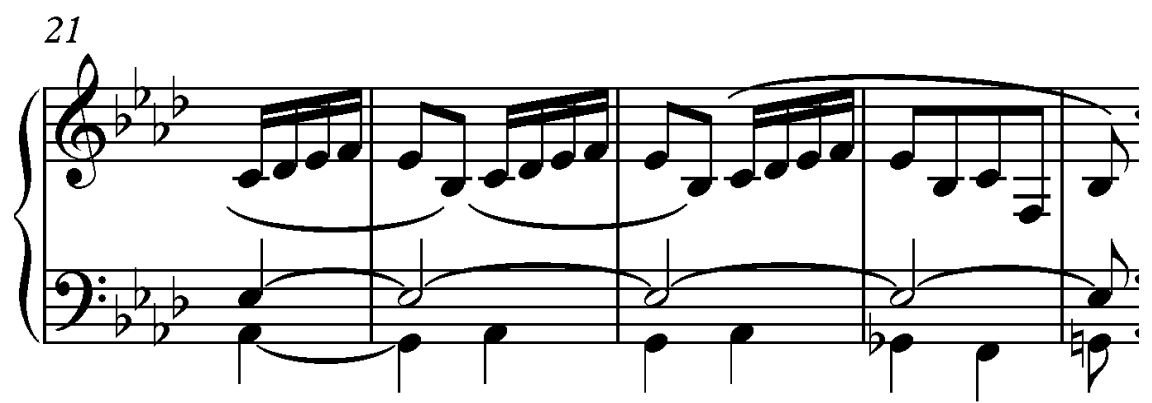

The new theme opens the B section in m. 54, marked ben tenuto and is a more chordal and powerful section as contrasted to the A section. This section begins with the A-flat Major chord and gradually moves to the E-flat (dominant key).

Example 4.5.18: Sonata in A-flat Major Op. 12 "Allegro" (fourth movement): B section theme (mm. 54-61).

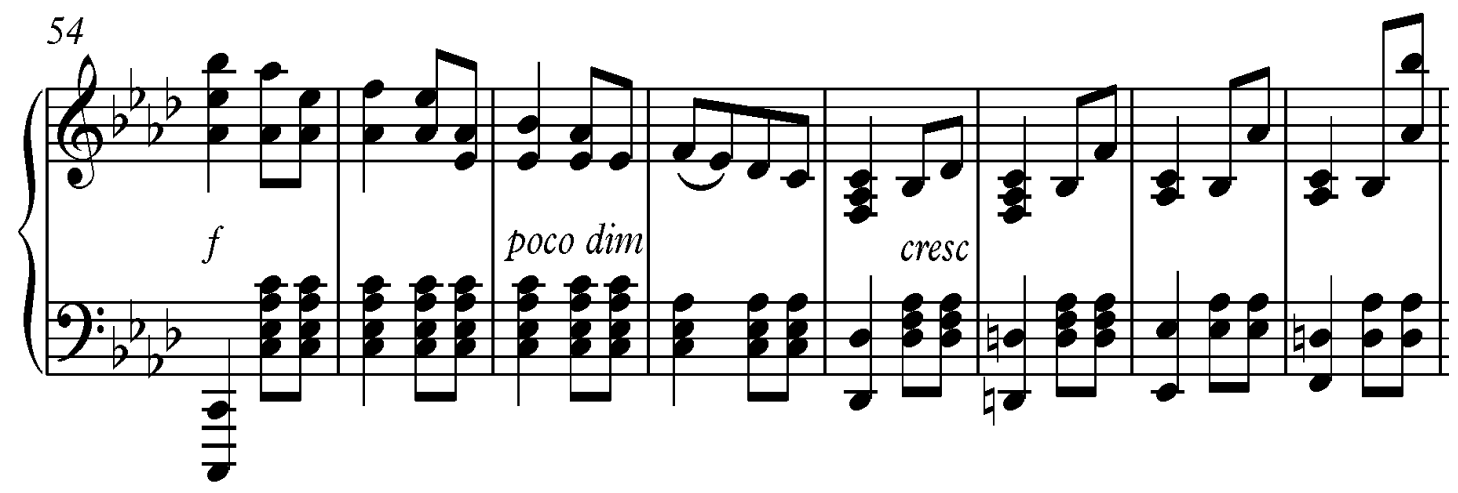


In the B section, the four-descending notes is a noticeable motive that has been used often in varied texture and accompaniment. It also modulates especially in $\mathrm{m} .133$. The motive has been expanded and modulated to a remote key: B Major (see example 4.5.19).

Example 4.5.19: Sonata in A-flat Major, Op. 12 "Allegro" (fourth movement): B section theme (mm. 133-140).

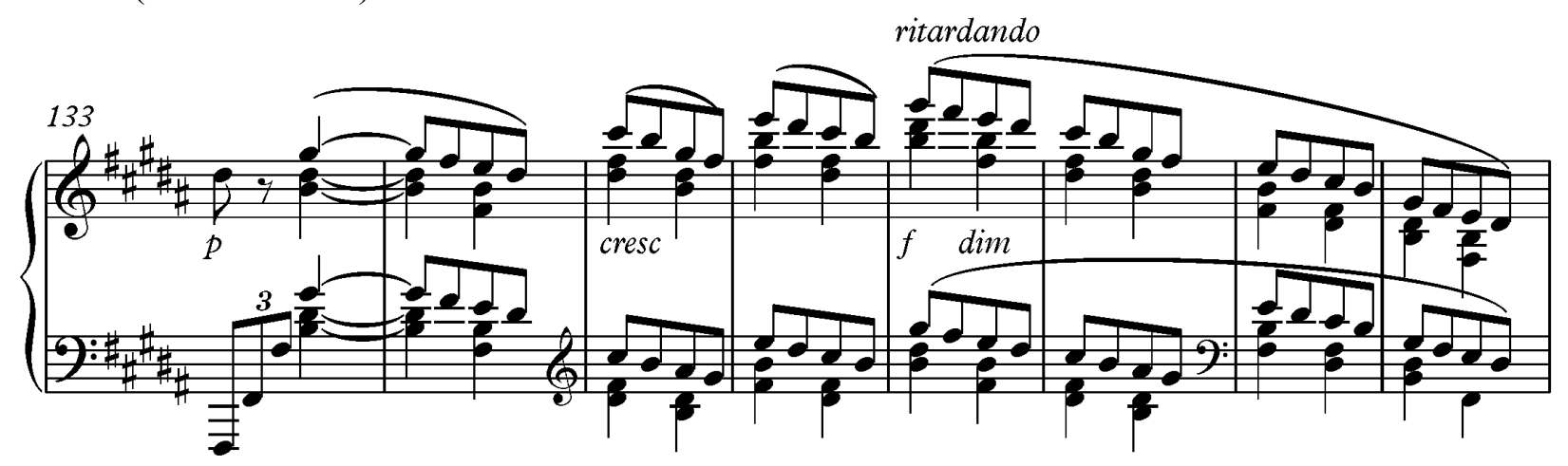

The C section, marked Tranquillo; molto expressivo, has more lyrical and expressive melodic lines between the soprano and tenor. It is like a duet accompanied by long notes in the alto and bass lines (see example 4.5.20).

Example 4.5.20: Sonata in A-flat Major, Op. 12 "Allegro" (fourth movement): C Section theme (mm. 141-146).

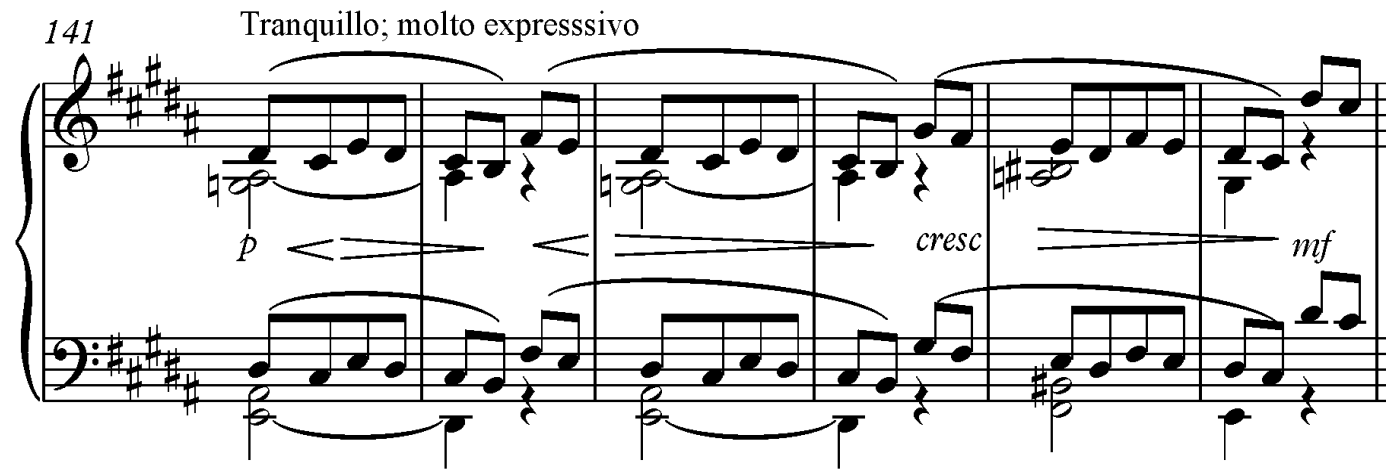

The $\mathrm{C}$ section is concluded by the reappearance of the motive from the A section. It is now altered and also marked Scherzando. This transition has more active sixteenth-note passages in both hands. The right hand passage is in a whole step descending sequence, whereas the left hand passage is in a chromatically descending sequence. 
Example 4.5.21: Sonata in A-flat Major, Op. 12 "Allegro" (fourth movement): A section themetransition (mm.21-24).

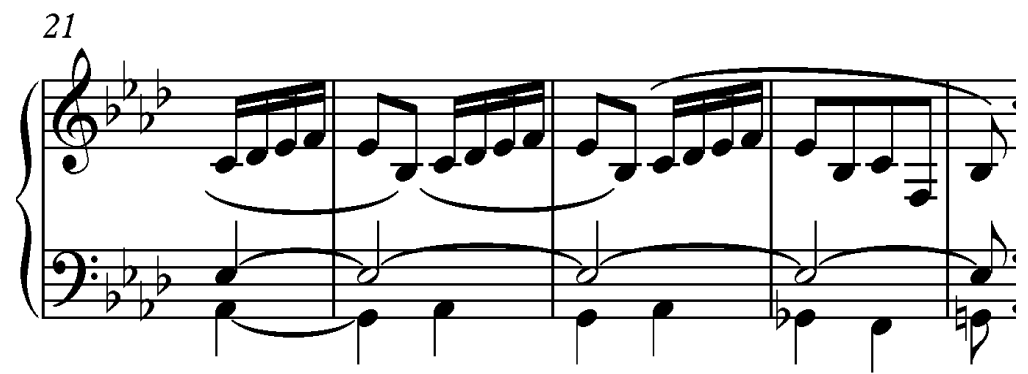

Example 4.5.22: Sonata in A-flat Major, Op. 12 "Allegro" (fourth movement): altered transition (Scherzando)

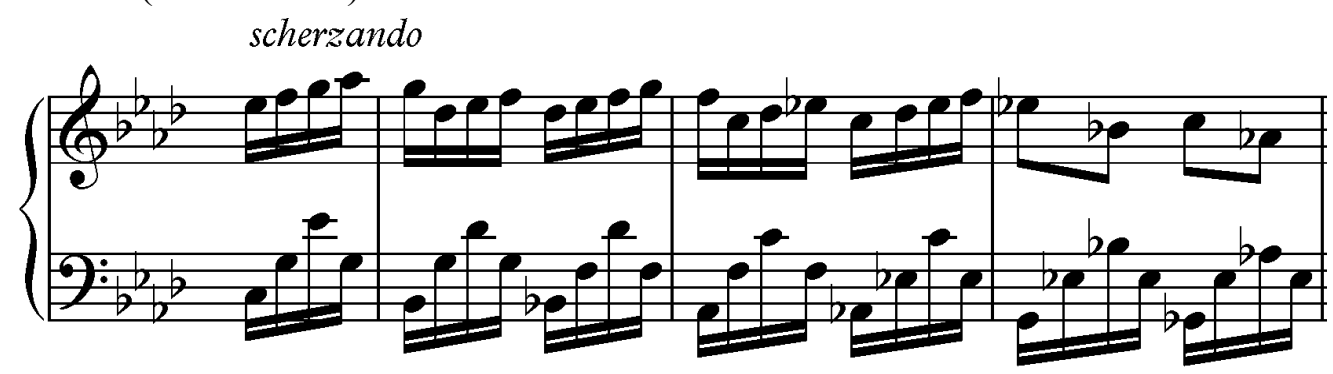

The return of the A section begins in the key of A-flat Major and gradually moves to C Major. Instead of the return of B, we now hear the return of $\mathrm{C}$ section in the key of A-flat major in $\mathrm{m} .300$. The B section finally returns in $\mathrm{m} .349$. It is in the key of A-flat Major and a different texture compared to the earlier B section. It is no longer chordal, but homophonic with left hand triplet accompaniment.

Example 4.5.23: Sonata in A-flat Major, Op. 12 "Allegro" (fourth movement): B section theme Altered (Mm. 349- 352).

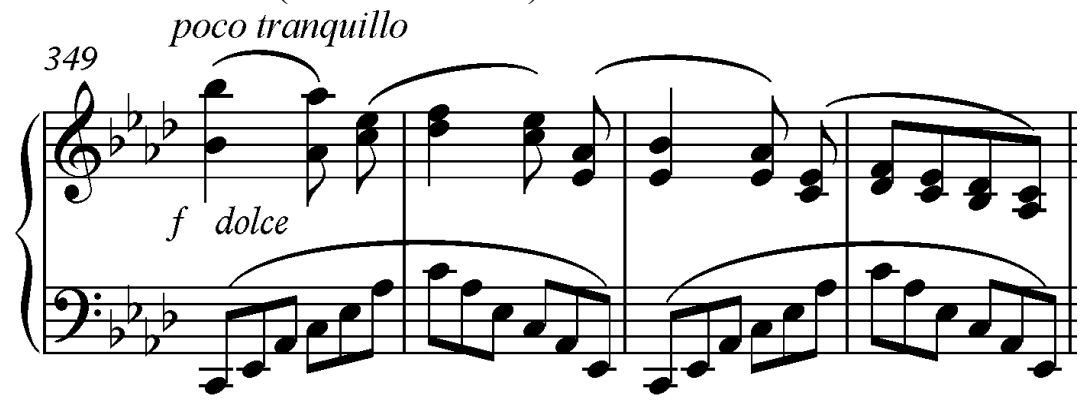


The Coda material is derived from the A section theme and is now expanded into triplets to create a fast-moving feel. The right hand octaves being accompanied by the enriched left hand doubling also support a more dramatic ending to conclude this sonata.

Example 4.5.24: Sonata in A-flat Major, Op. 12 "Allegro" (fourth movement): Coda

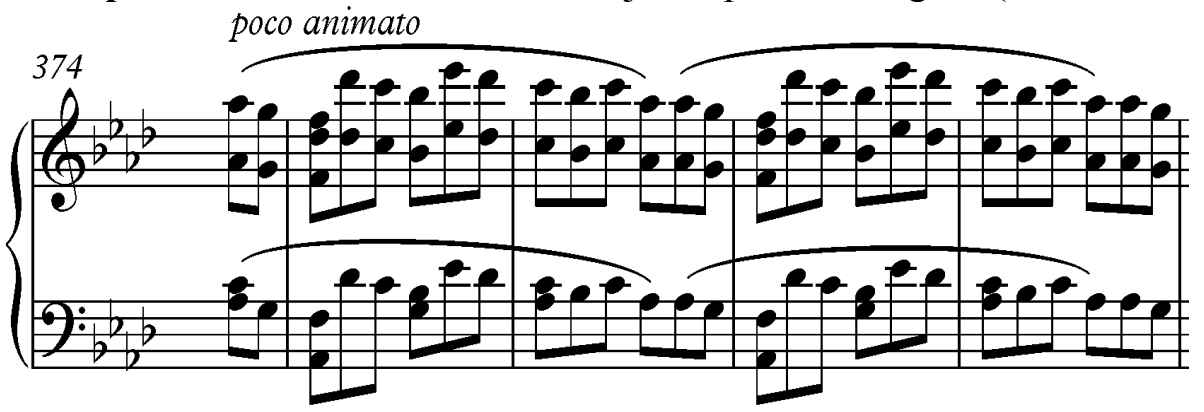

The markings of poco animando, stringendo, and molto animato indicate a gradually faster tempo which propels the arpeggio figures to the end. 


\section{CHAPTER V: Performance Suggestions for Piano Sonata in G minor}

This chapter will cover some suggestions for use or consideration while learning this piano sonata. It is hoped that these suggestions will be useful for improving the learning process as well as the performance. For performers, it is important to examine a piece thoroughly. Only by analyzing will it be apparent what elements need to be focused on and worked out throughout the practice process. Those elements include:

1. Analyzing the basic formal structure. This includes determining the form of the piece such as binary, ternary, rondo, or sonata-allegro form; the keys and the relationship; and basic harmonic progressions. This will be useful for a performer because it provides an outline of the piece. It also helps to understand better the structure and the unity of the piece. Later it will help for securing memorization. The formal analysis is included in the previous chapter.

2. Pedaling. The use of pedal will help to determine the quality of the tone that a performer wants to convey. Pedaling will enable different timbres and help with sustaining, connecting, creating expressiveness and warmth for a legato passage, and articulating staccato passages. It is essential to use pedal, and a performer must consider and make important decisions about the pedaling.

3. Phrasing and voicing. Not all music comes with performance notations from the composers or editors. It is a process of discovery, and one realizes more after analyzing and playing the pieces. A passage may need to be played several ways before the decisions are made. As for voicing, sometimes melody lines are concealed among the accompanying passages or under a rapid figuration. It will be a performer's duty to figure out and point out the melody lines. 
4. Interpreting. It is the process of exploring, deciding and interpreting the musical work.

This includes capturing the stylistic moods, tempo, and expressiveness.

5. Technical difficulties will be pointed out one by one through the piece.

The first movement: Allegro Vivace e Passionate

Suggested goal of performance tempo: quarter note $=112-126$ with rubato

Practice tempo: quarter note $=72-76$

The placement of eight-note triplets in the left hand accompanying the dotted eighth and sixteenth notes in the right hand raises a question. There is no general rule given for the execution. However, there are two possibilities of playing:

1. Subdivide the dotted eight-note into four sixteenths so the last sixteenth will be played after the last eight-note triplet (four against three feel).

2. The sixteenth will be played as the same time as the last eight-note triplet.

I prefer to play the rhythm as written.

Example 5.1: Sonata in G minor "Allegro Vivace e Passionate" ( $1^{\text {st }}$ movement): First theme (mm. 7-10)

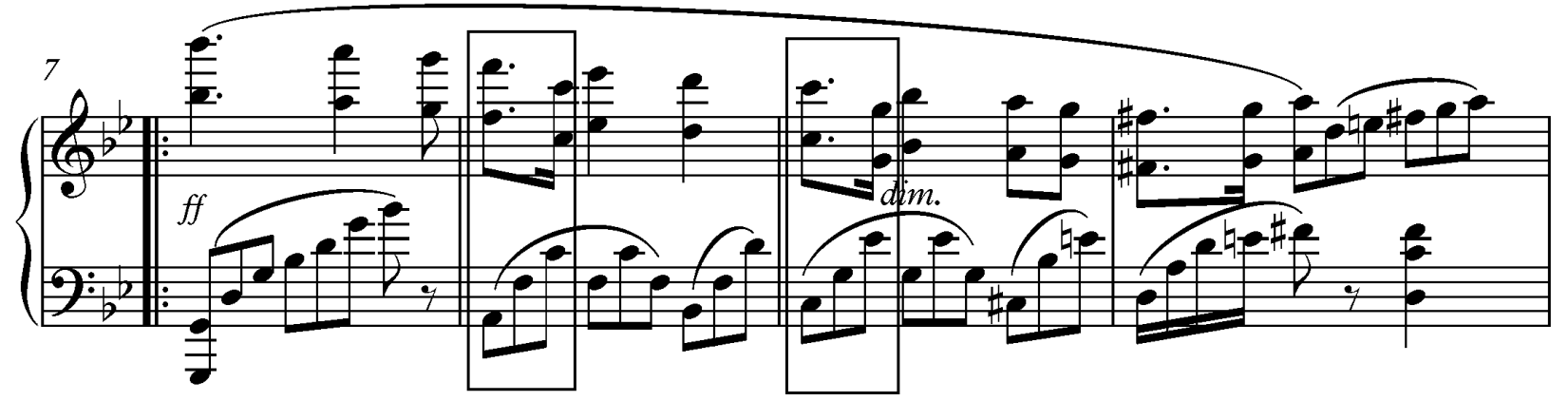

The use of the pedal may not be marked, but it is a common practice to use pedal in romantic music. A wide range of accompaniment figures is presented in the left hand; thus it is essential to incorporate pedal. However, it is important to decide the most effective pedaling without blurring the phrases or melody line in the right hand. Most of the time, changing the 
pedal at the beginning of each measure is recommended. Half note followed by quarter note pedal is recommended as the harmonic progression changes (see example 5.2).

Example 5.2: Sonata in G minor "Allegro Vivace e Passionate" ( $1^{\text {st }}$ movement): First theme (mm. 7-10)

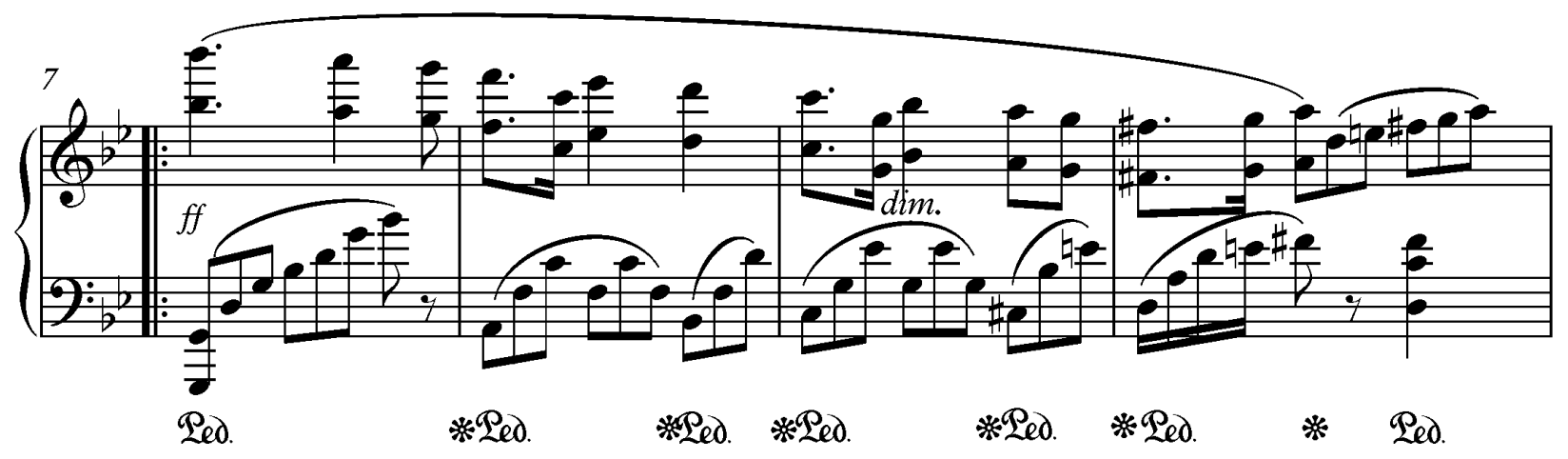

In the transition passage, the melody line is doubled between hands. The indication of animato suggests this passage is more flowing than the preceding passage. The rhythmic pattern of triplet against duplet needs to be played as smoothly as possible. There may be a lot of different solutions for this technical difficult passage. Personally, I do slow practice with quarter note metronome beat. In this case, I listen to the triplet's moving line and slowly add in the duplets. The first eighth-note is played simultaneously with the first eighth-note triplet; the second eighth-note is played between the second and third eighth note triplet (see example 5.3).

$$
\begin{aligned}
& \text { R.H: } 1223 \text { or Tri- pe- let } \\
& \text { L.H: } 1+\text { Du- ple }
\end{aligned}
$$

Example 5.3: Sonata in G minor "Allegro Vivace e Passionate" ( $1^{\text {st }}$ movement): the Transitional passage (mm. 31-35).

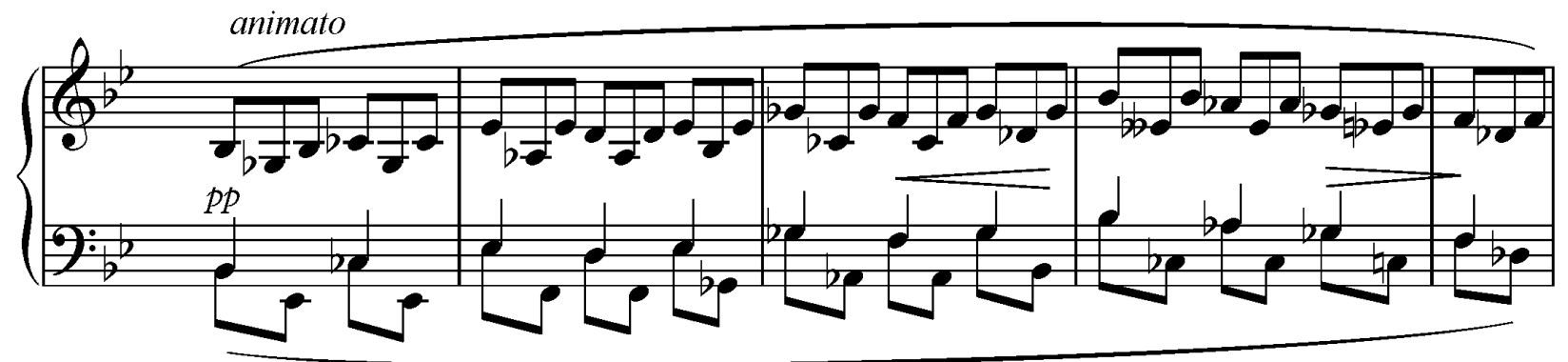


For the pedaling, I prefer the half note followed by quarter note pedal considering this passage needs to be played more animated. However, a performer may try different solutions. Changing pedal every single beat will enhance the clarity of the rhythm but may be problematic and may interrupt the continuity of the melodic line.

Distribution of weight between the theme and the accompaniment figures in the second theme requires a close observation. The right hand needs to point out the melody line in the upper voice and balance the accompanying descending broken chord moving into the left hand (see example 5.4). As indicated tranquillo, this passage needs to be played gently and lyrically. Musical artistry, including expressiveness is the essence of creating a beautiful sound and expressive phrases. It can easily become mechanical if one is not aware of the balance between the hands. With the wide range of this accompaniment, a longer pedal is recommended to sustain the melodic line and the continuity of the phrase.

Example 5.4: Sonata in G minor "Allegro Vivace e Passionate" ( $1^{\text {st }}$ movement): the Second theme (mm.55-62).
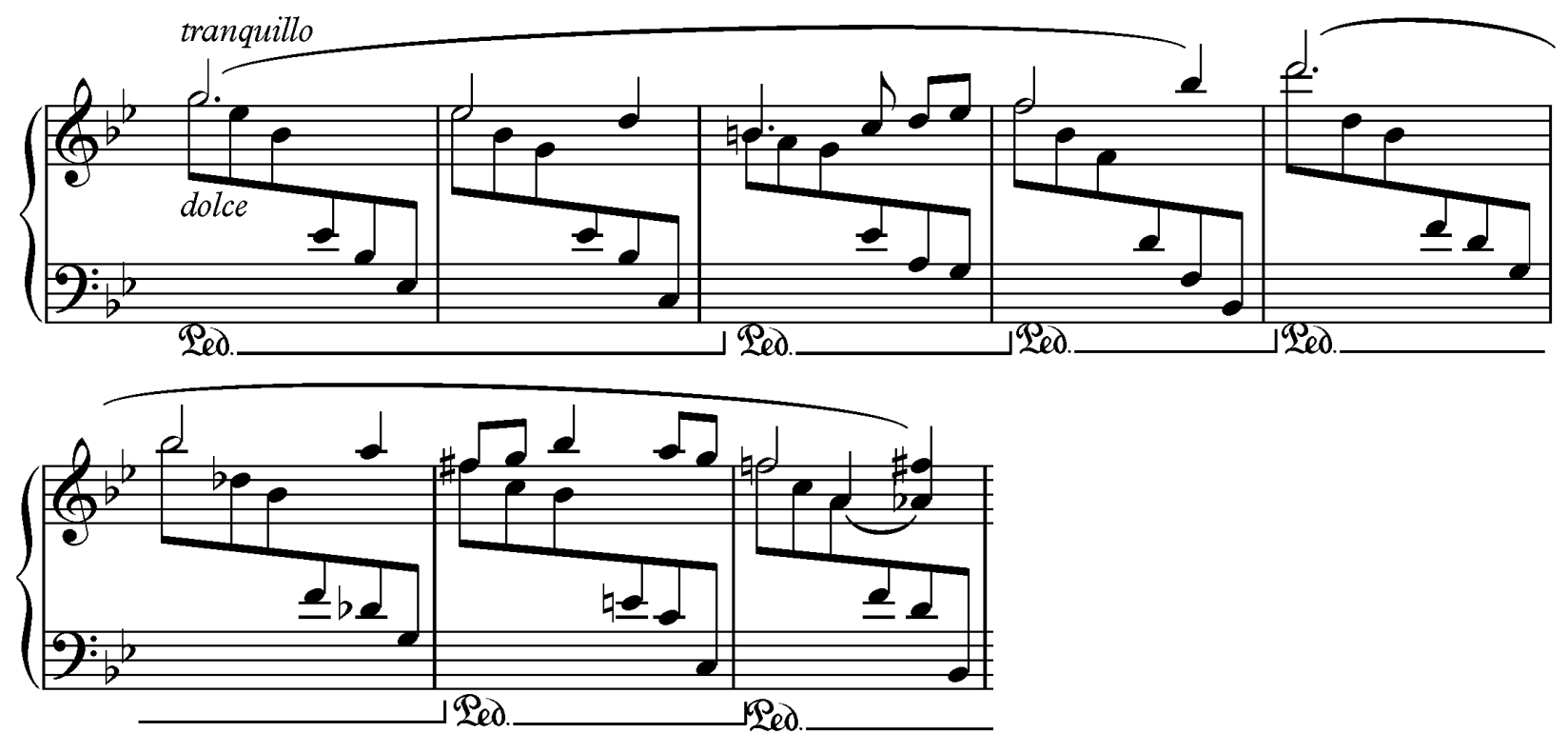

The Closing theme opens with sostenuto as indicated by the composer. Sostenuto means to sustain in duration. Perhaps a performer can interpret this as the implication of a slowing 
down tempo. Stenhammar presented the closing theme in the upper voice in the right hand accompanied by a long E-flat pedal point in the left hand. This prepares the tranquil feel that follows in measure 79 .

Example 5.5: Sonata in G minor "Allegro Vivace e Passionate" ( $1^{\text {st }}$ movement): the Closing theme (mm. 75-78).

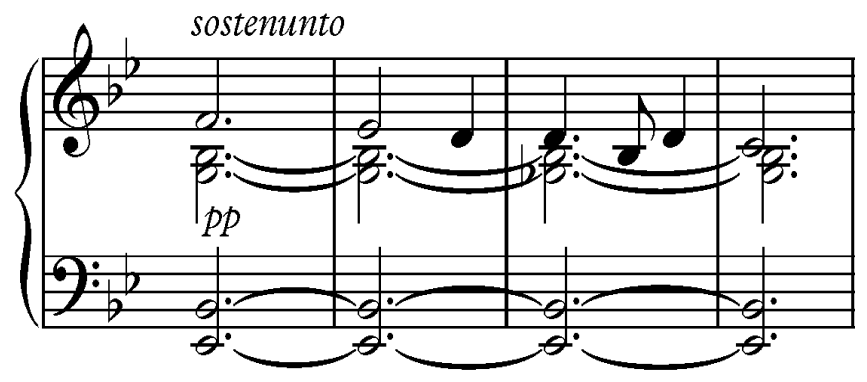

The closing theme reiterates and the indication molto tranquillo with ppp sempre, might suggest that the Una corda (soft pedal) should be depressed along with the damper pedal. This will help to produce a thinner timbre (from mm. 79-90) through the crescendo mark in m. 91. The una corda pedal is not only used as coloring device, but also to create contrasting moods among sections. The closing theme concludes as it returns to a six-measure phrase similar to the opening introduction, now in the dominant key and marked Vivace.

Example 5.6: Sonata in G minor "Allegro Vivace e Passionate" ( $1^{\text {st }}$ movement $)$ : Closing theme (mm. 79-82)

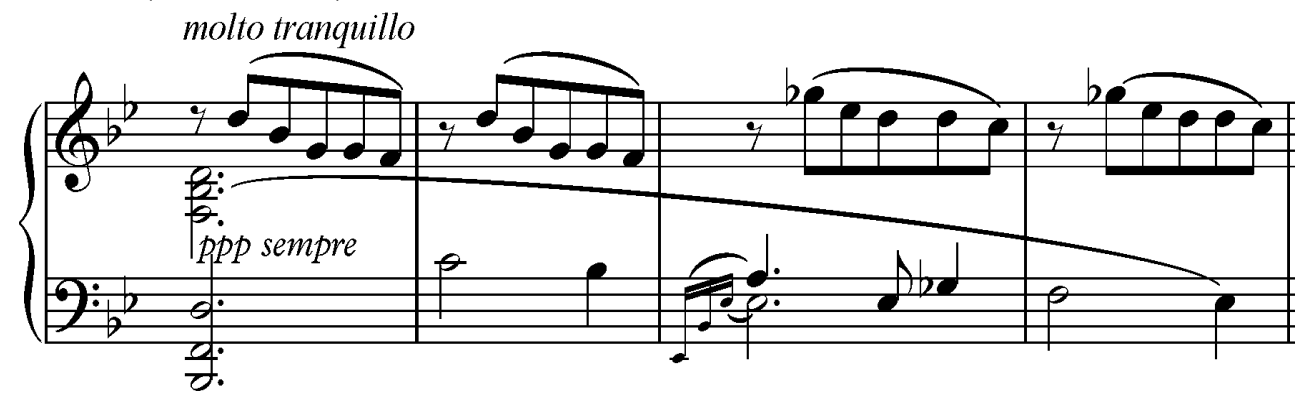

The end of the first movement presents a problem in pacing. The closing theme returns marked Sostenuto (m. 264) and molto tranquillo (m. 268), which leads to the transition now marked animato. At the end of the transition (m. 304-305), there is a ritardando that leads to the 
Coda. The Coda (return of the first theme material) is marked vivacissimo. This indicates to the performer that this return needs to be played a little faster than the earlier presentation of this theme. The concluding passage from m. 320 with ritardando and the sostenuto marked in m. 326 has an indication of tempo changes that suggests pulling back from the faster vivacissimo tempo.

As a performer, it raises different questions in regard to the different tempo designations. This includes how much faster should the vivacissimo need to be played. Personally, I think the tempo designation suggests different characters. The vivacissimo section needs to be moved ahead slightly, with a good energy and clarity in playing the technical passage. Coincidently, Stenhammar provides a slower ritardando or sostenuto section that leads to a faster section. This suggests a direct move away from the slow tempo and exaggerates the sense of motion on the faster tempo more.

The second movement: Romanza. Andante quasi adagio

This is a slow and lyrical movement. The pianistic problems include the balance between hands, the use of pedal, and the musical phrasing. The movement opens with bass notes followed by repeated chords in the left hand accompanying a single-note melody line in the right hand. The performer needs to be listening and projecting more of the melody line by using arm weight and rotation. Thus, the repeated chords may be played too detached causing the breaking of sound or are played with less control causing sudden attacks on particular chords. To avoid these problems, the repeated chords can be played with the wrist dropping and lifting: drop the wrist on the bass note, move the hand to the sustained repeated chords, and gradually lift the wrist while maintaining fingers close to the keys. The repeated chords need to be played very legato. Each chord needs to be sustained until the last moment possible before resounding. This will produce a nice quiet background to the lyrical melody. 
Example 5.7: Sonata in G minor "Romanza- Andante quasi Adagio" (second movement): First theme (mm. 1-5)
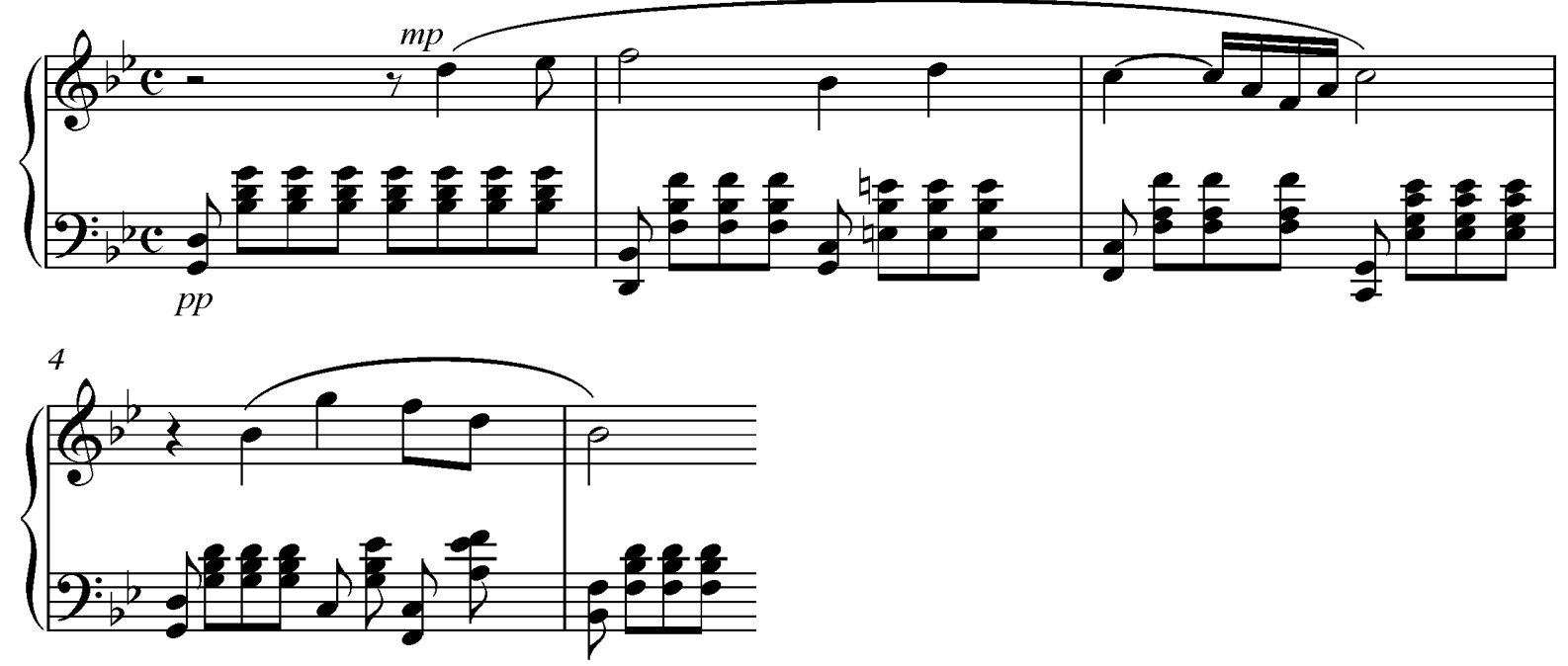

The use of pedal in this movement is straightforward. The pedal will be changed as the harmonic progression changes. The interpretation is essential to capture and convey the stylistic mood and to be expressive at the same time. The first theme passage seems to be gently growing with a steady eighth note chordal accompaniment.

In the second theme passage, the triplet accompaniment makes the passage seem more forward moving. Stenhammar also indicated poco piu animato: a little more animated. To have a seamless motion in the left hand, the technic of rotation, once again, is used to create the moving, even triplet background. The melody is the unifying feature of this movement and should be thought as continuous (see example 5.8).

Example 5.8: Sonata in G minor "Romanza- Andante quasi Adagio" (second movement): second theme (mm. 18-21).






\section{The Third Movement: Scherzo. Allegro Molto and Trio. Menno mosso (un pochettino)}

The articulation of staccato and legato will provide contrast on how the movement is perceived. The staccato passage is detached and played lightly without pedal. On the contrary, the legato passage is more connected with pedal and more arm-weight. Pedal is rarely used in the scherzo passage, mainly because of the staccato indication. However in mm. 29-36, a downbeat pedal is recommended to connect the two note slurs with the octave accompaniment in the left hand. The damper pedal needs to be released accurately on beat two to enhance the staccato effect (see example 5.9).

Example 5.9: Sonata in G minor, "Scherzo-Allegro Molto" ( $3^{\text {rd }}$ movement): mm. 29-36.

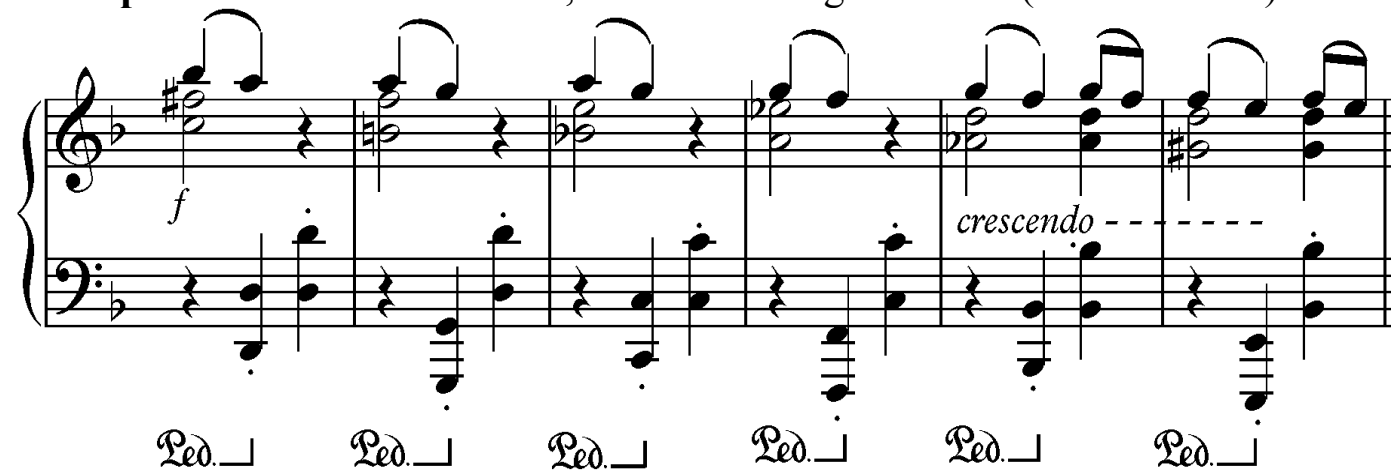

In the Trio as indicated meno mosso (un pochettino), perhaps a slower and relaxed tempo can be considered in order to play the more lyrical section. The melodic line is in the outer voice of the right hand, and the accompaniment is in the inner voices of the right hand and the left hand. Also legatissimo is marked in this passage, indicating that the musical phrasing of the passage needs to be played as smoothly and as connectedly as possible. With all these indications, we can presume that Stenhammar created a warm and expressive section in contrast with the preceding one of lively character. This passage needs to be played in a very legato manner by over holding the melody notes. The harmony is more static compared to the scherzo 
section. Primarily, a long pedal will be used in this passage. The damper pedal will help to sustain long pedal notes and connect the melody line.

Example 5.10: Sonata in G minor, "Trio-Meno Mosso (un pochettino)" ( $3^{\text {rd }}$ movement): mm. 69- 84 .

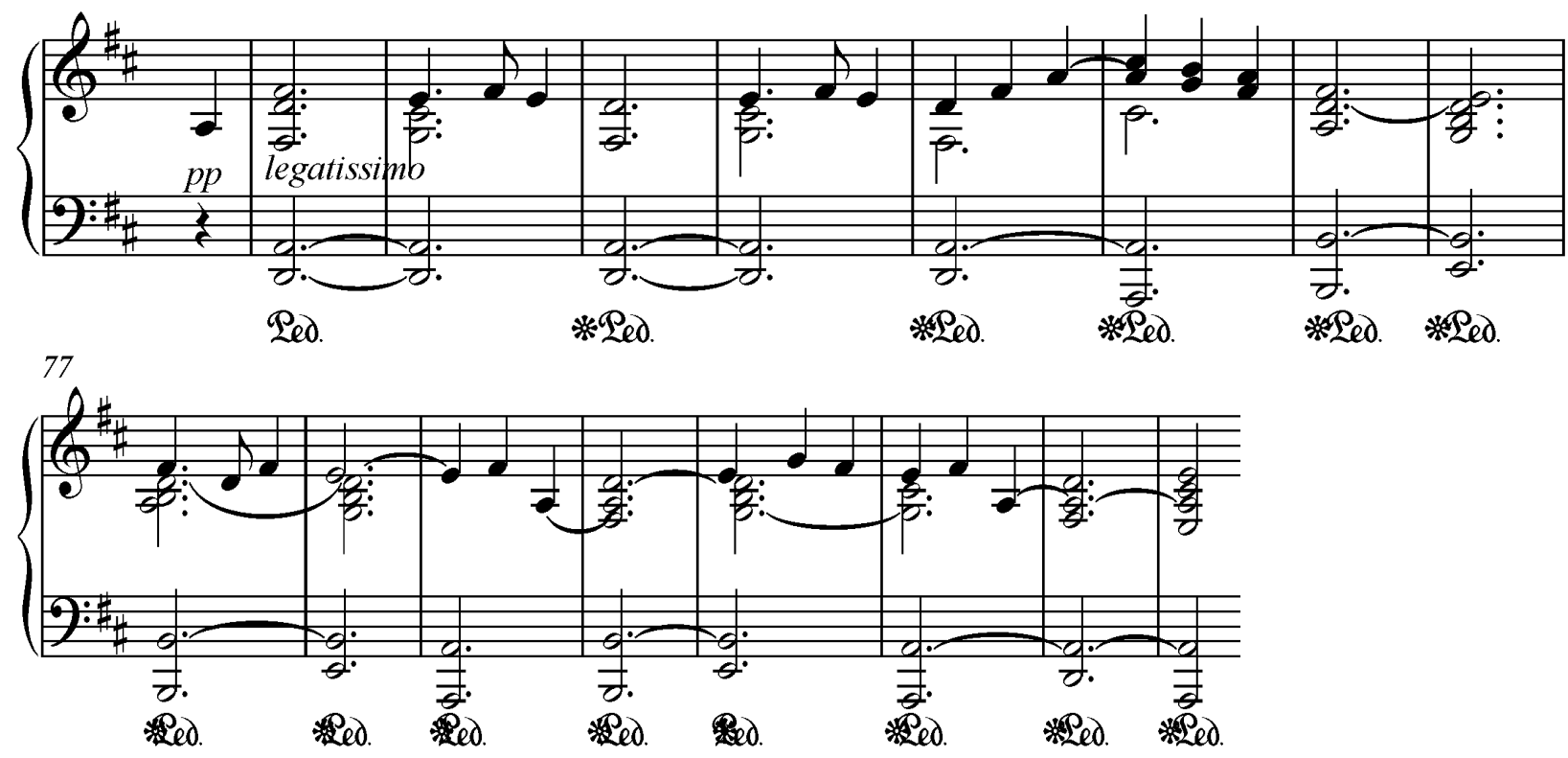

The fourth movement: Rondo. Allegressimo

This movement requires physical endurance. There are two main pianistic problems encountered in the first theme. First, the rapid sixteenth-note passage appears repeatedly each time the first theme returns. It is important to play this passage with relaxed and flexible arms and wrists. This is crucial to prevent injuries. Relaxed gestures will enable a performer to play Allegrissimo: with a lively tempo and better continuity of the musical phrase. It is important to use the rotation of the wrist for this sixteenth note passage. However due to the speed required in this piece, it is also suggested to use the drop and lift arm gesture for each group of sixteenth notes. This provides a relaxation of arms and wrists.

Secondly, a more complicated voicing is certainly found in this romantic music because the composer tends to insert melodic lines in the inner voices over the bustle of the outer voices. This is found at the beginning of this movement. It starts with the subtle soprano voice, followed 
by the bass voice, and the melody line enters in the tenor. Harmonically, it is important to bring out the bass line, but it should not overpower the melody line in the tenor voice. For this passage, primarily changing the pedal at the beginning of each measure is recommended because it will help sustain the bass line and connect the flow of the melodic line. An exception to this notion is in $\mathrm{m} .6$ and 10 where there is suspension resolution. The performer should choose either pedaling on beat 1 and releasing on beat 2 or vice versa. What is desired here is the illusion of legato in the bass line while highlighting the tenor melody (see example 5.11).

Example 5.11: Sonata in G minor "Rondo- Allegressimo" (fourth movement): first theme (mm. 1-10).
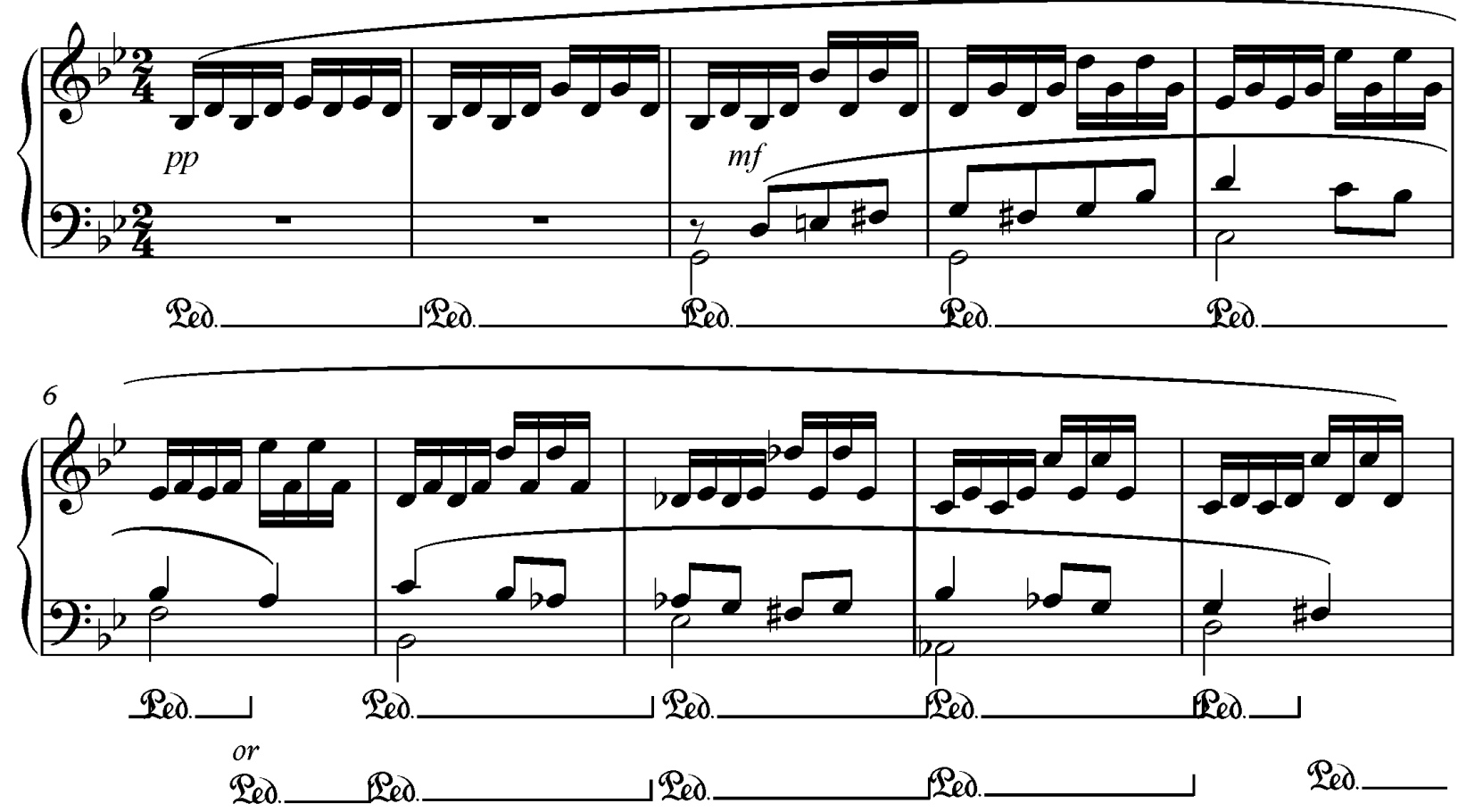

Expansion of the right hand passage starts in $\mathrm{m} .11$. The right hand has constant broken octaves. A performer needs to be listening for the voicing of the melodic line which is on top. It is technically challenging especially for relatively small hands. Alternating fingers (1-5 on the white keys to 1-4 on the black keys) with relaxed arms and the technic of rotation may help to voice the melodic line and prevent it from being played too mechanically. Simultaneously, a 
wide range of accompaniment figures is presented in the left hand. They are broken chords, with more than an octave stretch: the bass note is followed by higher fill-in sixteenth notes. It is suggested to practice left hand separately at a slow tempo. This will reinforce the independence of each hand movement. Many different forms of rhythmic practice can be used to accurately reinforce the left hand leap such as dotted rhythm (long and short or vice versa) or any variety of rhythmic groupings. Using a consistent fingering will facilitate the process of learning.

For this passage, changing the pedal at the beginning of each measure is recommended. It also helps to sustain the bass line and to move quickly to the fill-in sixteenth notes. An exception to this notion is (m. 14 and 18) where there is suspension resolution. The performer should be aware of harmonic changes where the pedal needs to be depressed on beat 1 and 2 .

Example 5.12: Sonata in G minor "Rondo- Allegressimo" (fourth movement): mm. 11-14.

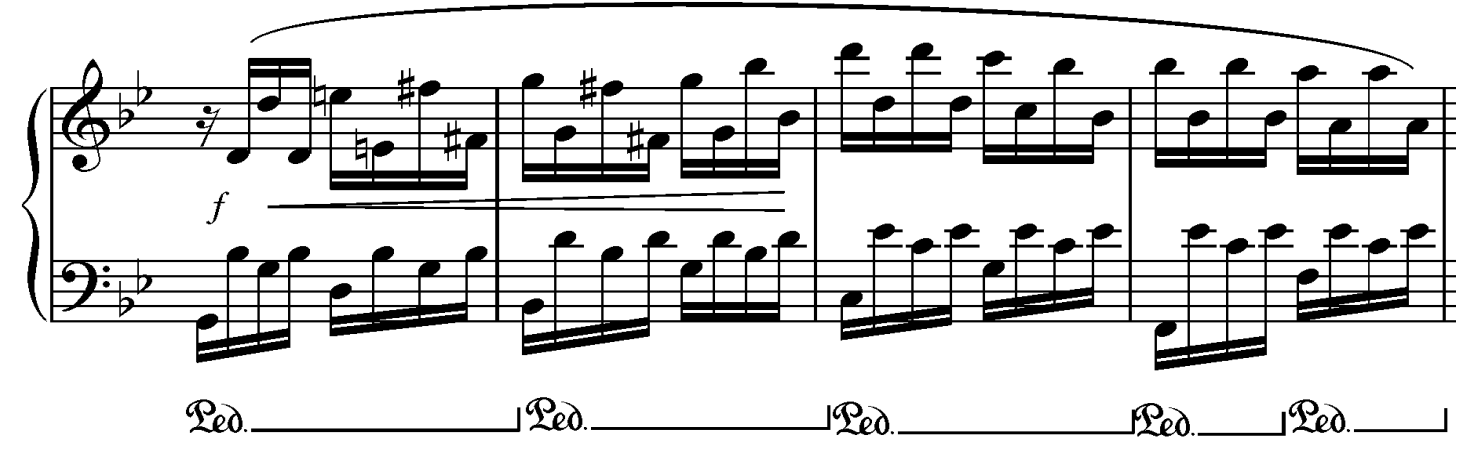

In the transition passage, pedal can be changed on beat 1 and 2. Pedal and hands should be lifted simultaneously. Also, the performer needs to be aware of the soprano melody line in the right hand moving to the the bottom note of the bass octaves in the left hand (see example 5.13) 
Example 5.13: Sonata in G minor "Rondo- Allegressimo" (fourth movement): transition (mm. 37-40)

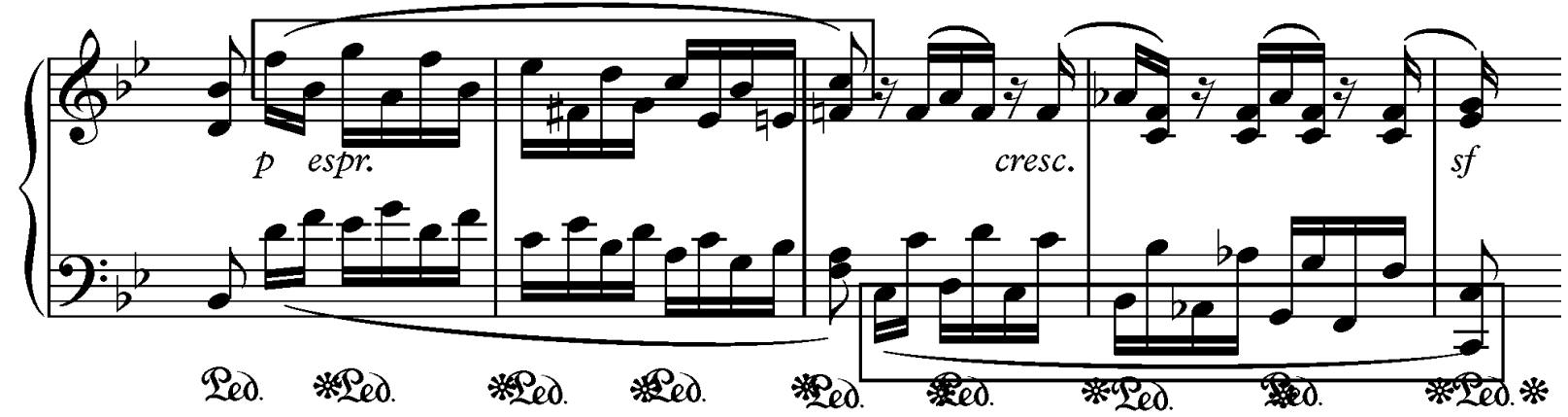

The third theme consists of alternation of legato and staccato passages (mm. 111-162).

Generally, I recommend a downbeat pedal. Pedal will be depressed on beat 1 and will be released on beat 2 . The staccato figures must be played without pedal and legato figures with pedal. This pedaling is used to vary the articulation of legato and staccato: this changes the character and creates contrast. This passage offers a contrasting folk dance-like character.

Example 5.14: Sonata in G minor "Rondo- Allegressimo" (fourth movement): third theme (mm. 111-114)

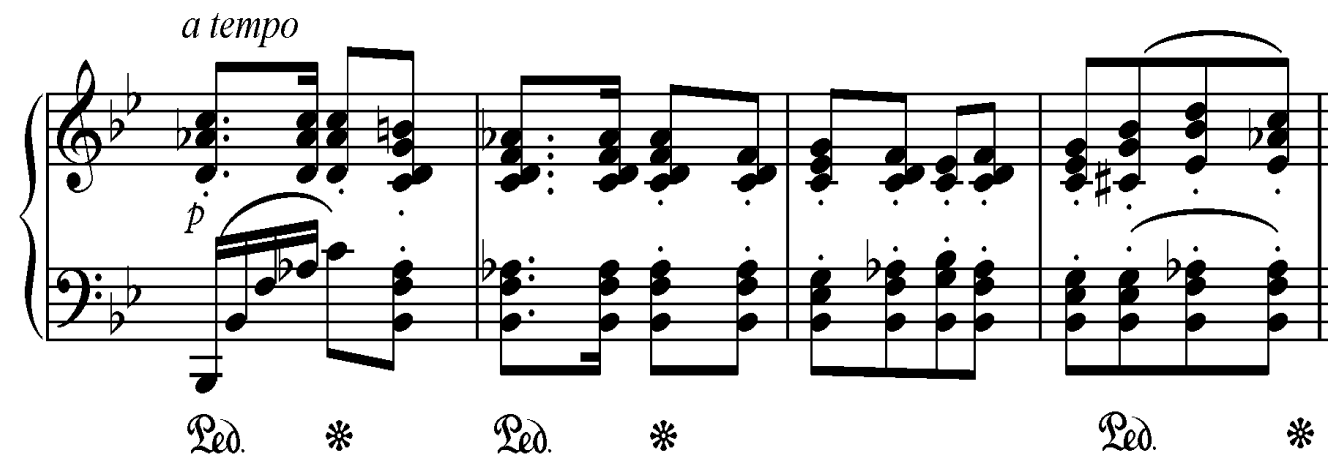

Stenhammar explored a wide range of dynamic markings, from a very delicate $p p$ to begin this movement to a fiery fff coda to conclude the sonata. The use of una corda and damper pedal will boost the dynamic contrast. The una corda pedal may be used in any section that is marked $p p$ : for example in the Sostenuto passage in $\mathrm{mm}$. 229-250). This will provide a better dynamic planning and will create contrast of the tone color. 
In the Coda section, the technical difficulty that will be encountered is the double-note passage in the right hand accompanied by a wide leap broken chord in the left hand. Fingering should be carefully considered in the double-note passage.

Example 5.15: Sonata in G minor "Rondo- Allegressimo" (fourth movement): Coda (mm.277-280).

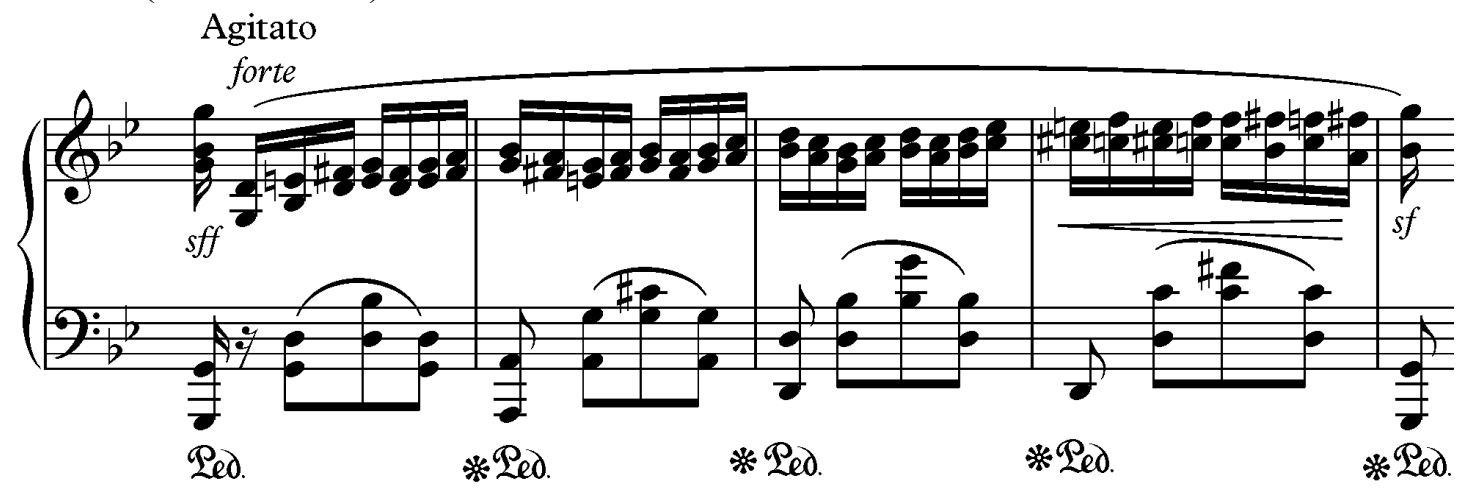

Example 5.16: Sonata in G minor "Rondo- Allegressimo" (fourth movement): Coda right hand with possible fingering (mm.277-280).

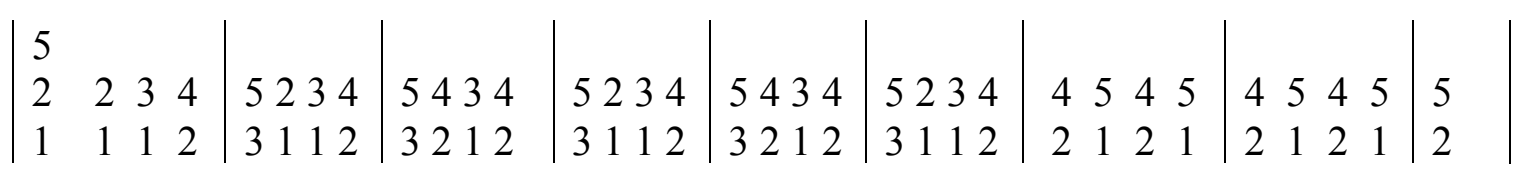

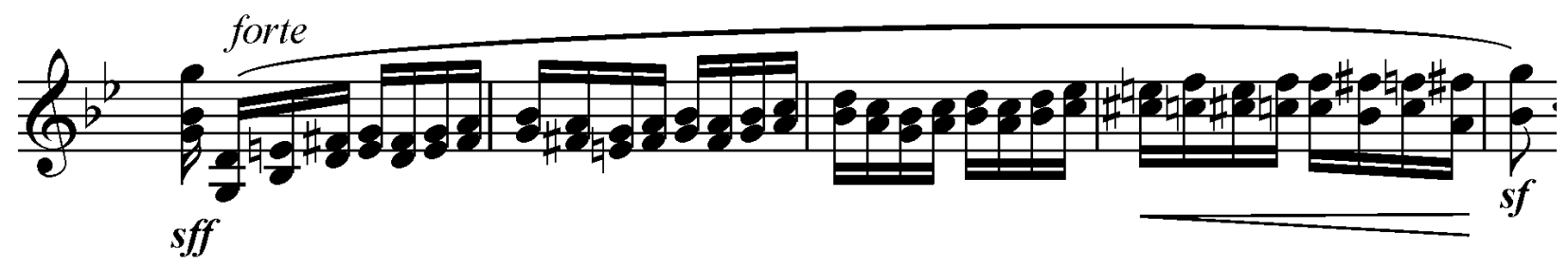

The left hand passage has an octave bass note followed by broken chord accompanying figures. Since these passages exceed the stretch of hand, it is important to figure out how to reach the passage without injury. Slow separate hand practice helps to discover the most comfortable wrist and hand motion. The hand position will be turned sideways from the wrist while playing the broken-chord and is combined with the flexible forearm. It moves from the left to right and back again in rotary movement. The second finger will be used as a pivot and remains firmly in contact with key. It should be placed first allowing the thumb to stretch. 
Example 5.17: Sonata in G minor "Rondo- Allegressimo" (fourth movement):: Coda (mm.277280) L.H alone.

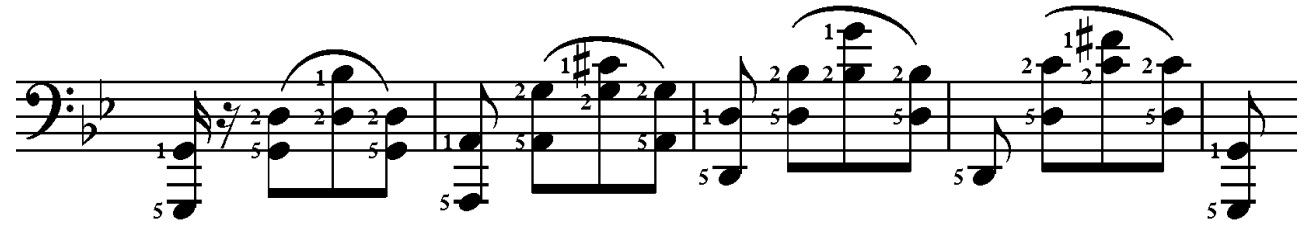

or

$$
\begin{aligned}
& \begin{array}{lllll|llll|llll|lll|l}
1 & 2 & 1 & 2 & 1 & 2 & 1 & 2 & 1 & 2 & 1 & 2 & & 2 & 1 & 2 & 1
\end{array} \\
& \begin{array}{llll|llll|llll|llll|l}
5 & 5 & 3 & 5 & 5 & 5 & 3 & 5 & 5 & 5 & 3 & 5 & 5 & 5 & 3 & 5 & 5
\end{array}
\end{aligned}
$$

A slight holding back, like ritardando, proceeds each faster section and makes more musical sense by bringing out the significance of this gradual accelerando. Each passage demands a faster tempo than the preceding passage, and it seems to require the quickest speed that a pianist can possibly acquire. However, performers need to make a determination on how fast it needs to be played without ignoring the clarity and the beauty of the passages. It is hoped that these suggestions will assist in the learning process for pianists working on this sonata. 


\section{CHAPTER VI: Summary and Suggestions for Future Research}

\section{Summary}

Wilhelm Stenhammar was born in Stockholm on February 7,1871 and died in Stockholm on November 20,1927. The young Stenhammar grew up in a respected, cultural, religious, and musical family in Stockholm. He showed ability to play the piano and to compose at an early age even without much formal training. His childhood composition includes the little-known three piano sonatas: C Major (1880), C minor (1881), and A-flat Major (1885). These sonatas are in the style of August Söderman ${ }^{42}(1832-1876)$ as well as other classic composers like Mozart and Schubert. $^{43}$

Stenhammar received his first formal training at the age of sixteen in 1887 . He began his piano studies with the prominent Swedish teacher Richard Andersson, who was a student of Clara Schumann. Andersson introduced the young Stenhammar to the works of the Classic (Mozart and Beethoven) and Romantic (Chopin, and Schumann) composers. Andersson also transformed the young Stenhammar into a virtuoso pianist. Stenhammar became familiar with European art music which inspired him to write in that style.

Stenhammar developed his pianistic skills and became a virtuoso pianist. His repertoire included a large number of Mozart's works, Beethoven's sonatas, accompaniments and chamber music. ${ }^{44}$ His foremost public recognition occurred in 1892 performing extensively as a pianist. He gave a successful performance of Brahms' D minor piano concerto in Stockholm, and collaborated with the nationally famous Aulin Quartet. ${ }^{45}$

\footnotetext{
${ }^{42}$ Kathleen Dale and Axel Helmer, “August Söderman” In Grove Music Online. Oxford Music Online, http:/www.oxfordmusiconline.com/subscriber/article/grove/music $/ 26088$ ?q=August $+\mathrm{S} \% \mathrm{C} 3 \% \mathrm{~B} 6 \mathrm{derman}+\& \mathrm{search}=$ quick\&pos=1\& start=1\#firsthit (accessed March 25, 2014).

${ }^{43}$ Frost, 31 .

44 Ibid., 32.

${ }^{45}$ Litell, 79.
} 
As one of the finest Swedish pianists and composers of his time, one might expect that the piano will be the primary medium and will occupy the center position in his output. In fact, he wrote surprisingly few piano works and only few of them were published during his lifetime. The three published piano works were Three Fantasies, Op. 11 (1895), Sonata in A-flat Major, Op. 12 (1895), and Sensommarnätter, Op. 33 (1900). The rest of his piano solo works were donated to the Music Library of Sweden after Stenhammar's death. This includes his piano sonata in $\mathrm{G}$ minor.

The manuscript of the G minor Piano Sonata was rediscovered and was recently published in 2008. His compositional style was of a late romanticist with roots in the music of Mozart, Beethoven, Chopin, and Schumann. Unlike other nationalist composers at his time, he made little use of folk elements in his music. In addition to the piano works, he continued composing in a variety of genres throughout his career. Included are two symphonies, a violin sonata, six string quartets, opera and choral works including the small-scale Lieder, cantatas and large-scale works for chorus and orchestra. ${ }^{46}$

His childhood piano sonatas are generally small-scale and are quite well composed for a young boy. They also reveal indirect influences by different composers and demonstrate his ability to develop the sonata genre. Each sonata shows the development of the form: from a symmetrical binary form to a fully developed sonata allegro form. They also include the increasing technical demands in the later sonatas ( $\mathrm{G}$ minor and A-flat Major, Op. 12). Both of these sonatas are approximately 25-28 minutes and require much more technique and physical endurance. They are better suited for more advanced students or performers who are interested in Scandinavian piano repertoire.

\footnotetext{
${ }^{46}$ Bo Wallner and Hans Astrand, Stenhammar. http://www.oxfordmusiconline.com/subscriber/article_works/grove/music/26677\#S26677.1
} 
As discussed in chapter four, the g minor piano sonata is one of his prominent works in the sonata form. This sonata follows a traditional four-movement form that consists of: (I) Allegro Vivace e Passionato; (II) Andante quasi Adagio; (III) Scherzo and Trio; and (IV) Rondo. The approximate length of this sonata is about 25 minutes. Perhaps, this could be regarded as Stenhammar's first mature piano work. Stenhammar integrated and expanded different stylistic elements to bring to it a more sophisticated quality than his earlier sonatas.

The increase of technical demands and pianistic requirements become more evident in the G minor sonata. Therefore a discussion of performer suggestions is included in chapter five. It is hoped that these suggestions will be useful for improving the learning process as well as the performance. The performance suggestions include the elements of analyzing musical structure, pedaling, voicing and phrasing, interpreting, and handling some technically challenging passages.

While developing his compositional style, Stenhammar was very much aware of and was influenced by Schumann. It is interesting to note that there are a number of striking similarities between Schumman's piano sonata in G minor, Op. 22 and Stenhammar's sonata in G minor. Schumann composed his sonata in 1831 and revised it in 1838 whereas Stenhammar composed his sonata in 1890. These two sonatas are structurally similar and follow a traditional fourmovement form that consists of:

\begin{tabular}{|c|c|}
\hline $\begin{array}{l}\text { Schumann: Sonata in G minor Op. } 22 \\
\text { I. Prestissimo } \\
\text { II. Andantino } \\
\text { III. Scherzo } \\
\text { IV. Rondo }\end{array}$ & $\begin{array}{l}\text { Stenhammar: Sonata in G minor } \\
\text { I. Allegro Vivace e passionato } \\
\text { II. Romanza. Andante quasi adagio } \\
\text { III. Scherzo and Trio } \\
\text { IV. Rondo. Allegressimo }\end{array}$ \\
\hline
\end{tabular}


The first movement of both sonatas starts with an introduction, followed by the first theme in the key of G minor. The first theme's motive is a descending passage set in the right hand and accompanied by widely arpeggiated passage in the left hand (see example 6.1 and 6.2).

Example 6.1: Schumann Sonata in G minor Op. 22 ( $1^{\text {st }}$ movement): The first theme (mm. 4-9)
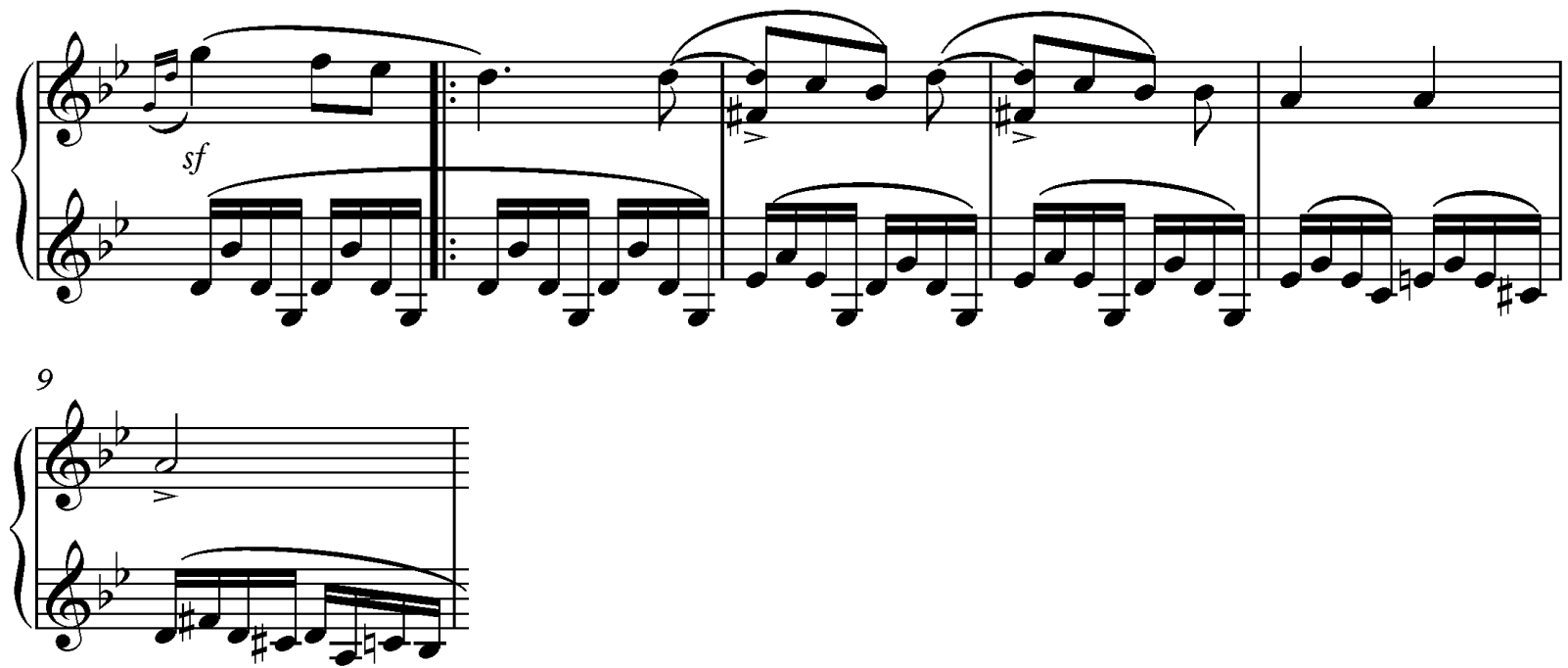

Example 6.2: Stenhammar Sonata in $\mathrm{G}$ minor ( $\left(1^{\text {st }}\right.$ movement $): 1^{\text {st }}$ theme (mm. 7-10)

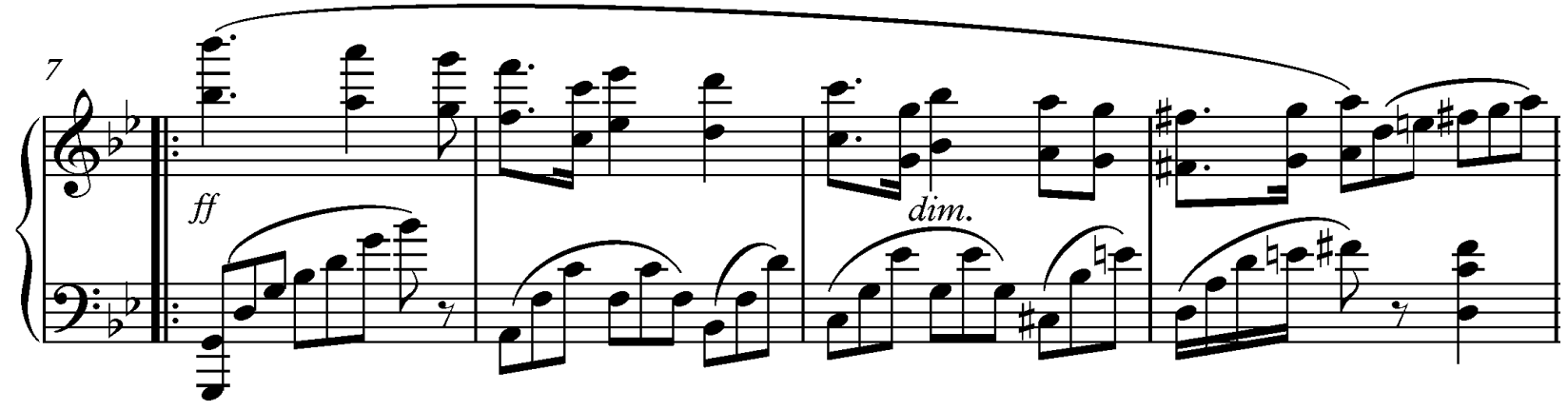

More lyrical second themes provide repose from the more passionate first themes and are in the key of B-flat Major, even though the texture for each sonata is differently presented.

In the Development section, both sonatas open with the introductory material starting in the key of G Major and gradually modulating. In the recapitulation section, the second theme in both sonatas is in the key of G Major. The Coda is based on the material of the first theme and is marked faster than the beginning tempo (piu mosso and piu mosso ancora in Schumann; animato 
and vivacissimo in Stenhammar). The first movements of both sonatas conclude passionately with a dramatic ending.

The second movements have similarities in the texture, the mood, and the form. These slow movements are written in ternary form. Both movements open with blocked-notes or chordal accompaniment before the arrival of the first theme, which is accompanied by steady eight notes (see example 6.3 and 6.4).

Example 6.3: Schumann Sonata in G minor Op, 22 (2nd movement): $1^{\text {st }}$ theme (mm.1-5).

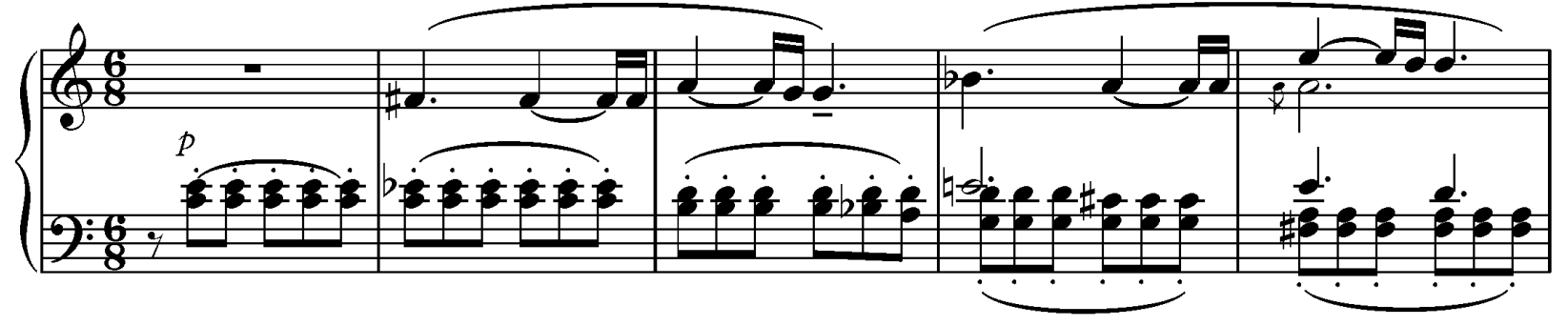

Example 6.4: Stenhammar sonata in G minor ( $2^{\text {nd }}$ movement): $1^{\text {st }}$ theme (mm.1-4).
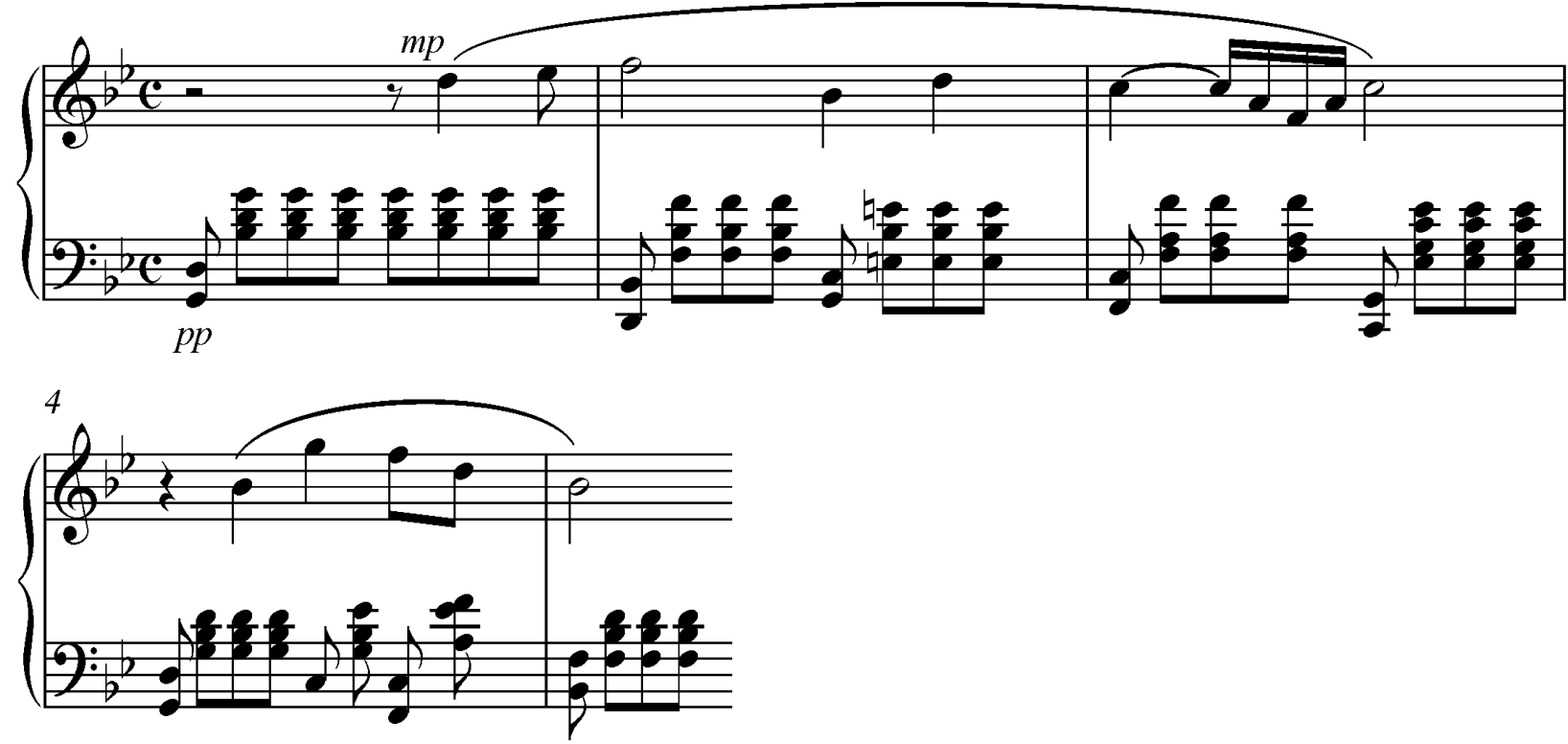

The second theme in both sonatas remains expressive and lyrical and is accompanied by more active accompaniments. 
The third movement in each sonata is a scherzo. Each movement has its own individual characteristic. However, they are in different keys (Schumann in G minor, and Stenhammar in D minor).

The fourth movement in both sonatas is in rondo form and the contrasting themes show distinctive characteristics which clearly define the sections. The first theme is presented as a lyrical and expressive melody and enters in the tenor voice under a rapid sixteenth note accompaniment in the right hand (see example 6.5 and 6.6).

Example 6.5: Schumann Sonata in G minor Op. 22 (4th movement): (mm.1-4).

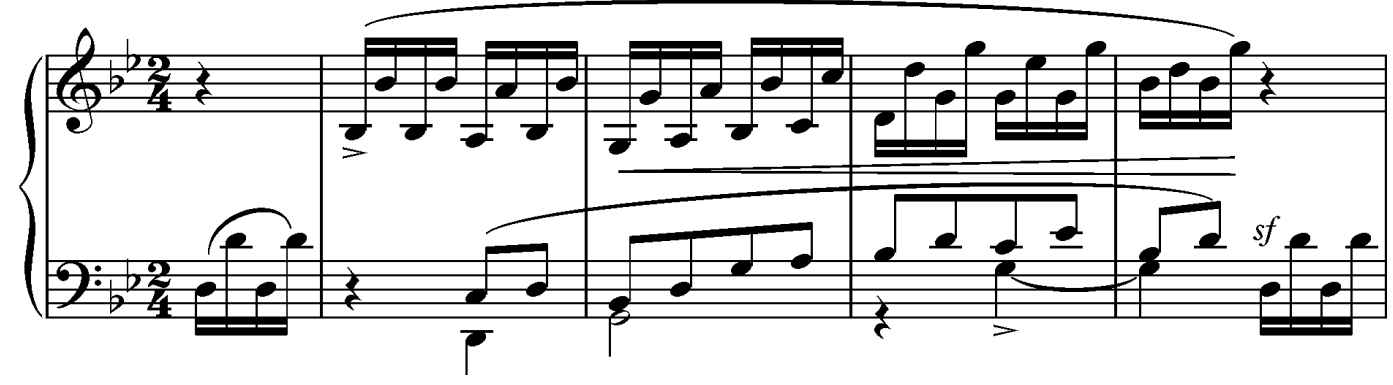

Example 6.6: Stenhammar sonata in G minor (fourth movement): (mm. 1-10).

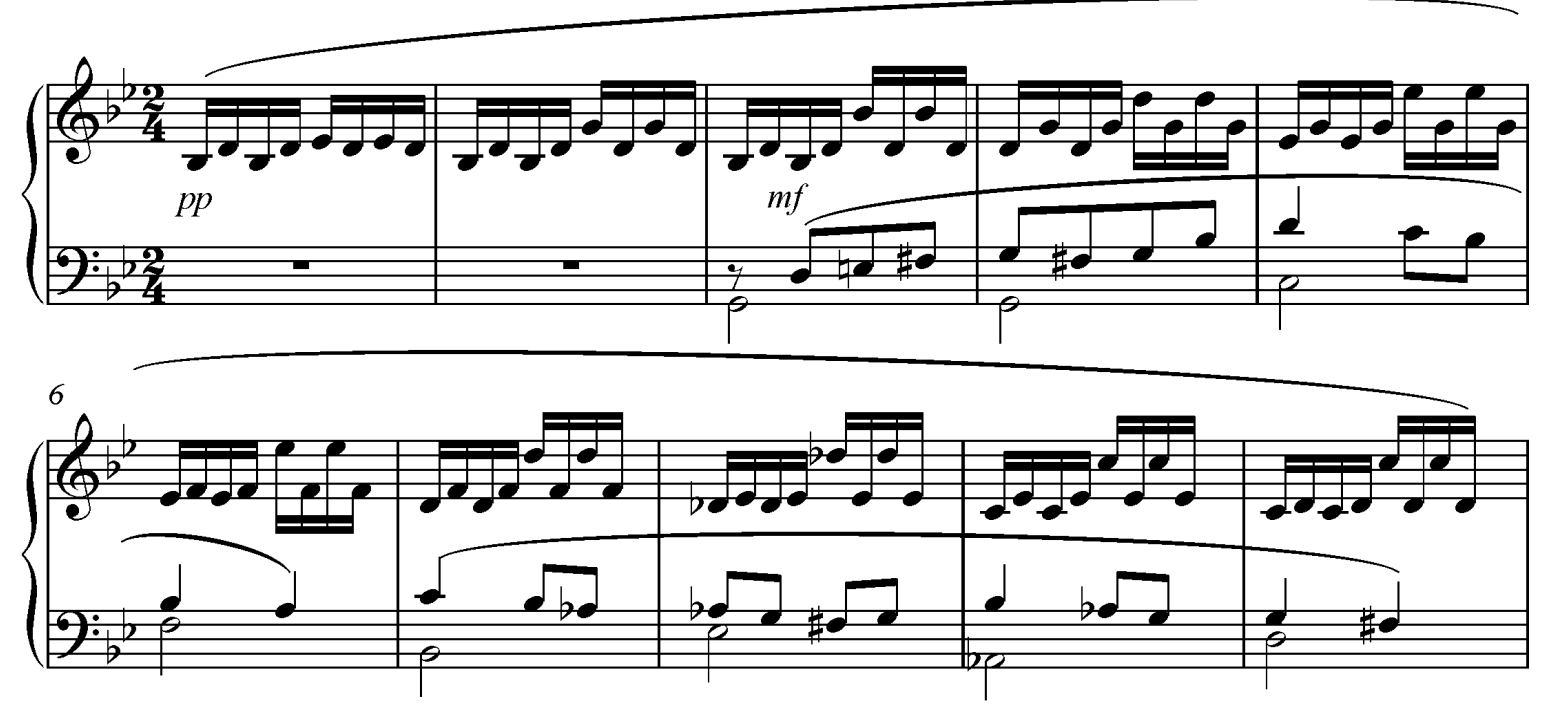

After the opening, there are few similarities between the two sonatas until we reach the coda. In the coda, each sonata opens with perpetual motion sixteenth notes, with gradual acceleration of tempi, and with a final statement of the main theme at the end. The acceleration 
of tempi are clearly indicated by the composers' markings (Prestissimo and Piu Presto in Schumann; Molto vivace and Presto possible in Stenhammar). The influence of Schumann can be seen most clearly in the first and last movements of the two sonatas.

\section{Suggestions for future research}

At this point of history, Stenhammar is still a lesser-known composer in this country. With this research paper, it is hoped to provide a useful discussion of Stenhammar's piano sonatas and hopefully will increase awareness and appreciation of his sonatas. Of the five piano sonatas, the G minor and A-flat Major Op. 12 are considered substantial works and they deserve more performances. Suggestions for further research could include a study of the Sonata in Aflat Major Op. 12, a study of character pieces for piano and a study of the piano concerti. This paper may serve as a guide and provide possible research materials for teachers, students, and musicians who are interested in Stenhammar. In this way, it may even interest others in the discovery and presentation of piano works which are not included in the traditional concert repertoire. 


\section{Selected Bibliography}

$\underline{\text { Books }}$

Dubal, David. The Art of the Piano: Its Performance, Literature, and Recordings. New Jersey: Amadeus Press, 2004.

Gordon, Stewart. A History of Keyboard Literature: Music for the Piano and its Forerunners. New York: Schirmer Books, 1996.

Hinson, Maurice and Irwin Freundlich, ed. Guide to the Pianist's Repertoire. Bloomington: Indiana University Press, 1973.

Johansson, Annette. Thirty Songs of Wilhelm Stenhammar: The Composer and His Romancer. NewYork: Leyerle Publications, 1999.

Kirby, Frank. Music for Piano: A Short History of Keyboard Music. New York: Free Press, 1966.

Morin, Alexander. Classical Music: The Listener's Companion. San Francisco, CA: Backbeat Books, 2002.

Quist, Robert. The History of Modern Swedish Music: An Introduction to Nineteenth Composers. New York: The Edwin Mellen Press, 2010.

Wallner, Bo. Stenhammar. Sweden: Swedish Music Information Center Stockholm, 1972.

Woodstra, Chris, Gerald Brennan, and Allen Schrott. All Music Guide to Classical Music: The Definitive Guide to Classical Music. San Francisco, CA: Backbeat Books Publisher, 2005.

Article in Journals and Online Databases

Bertil van Boer (trans.) "Musiken i Sverige. Vol. 2: Frihetstid och Gustaviansk Tid 1720-1810 by Leif Jonsson and Anna Ivarsdotter Johnson; Musiken i Sverige. Vol. 3: Den nationella Identiteten 1810-1920 by Leif Jonnson and Martin Tegen." Scandinavian Studies 66, no. 3 (Summer 1994): 449-453

Bo Wallner and Hans Åstrand. "Stenhammar, Wilhelm." In Grove Music Online. Oxford Music Online, http://www.oxfordmusiconline.com/subscriber/article/grove/music/26677 (accessed August 26, 2013).

Graham, Carritt. "Swedish Music: Past and Present." The Musical Times 80, No. 1151 (January 1939): 16-17. 
Johnson, Stephen. "Stenhammar, (Karl) Wilhelm (Eugen)." In The Oxford Companion to Music. Oxford Music Online, http://www.oxfordmusiconline.com/subscriber/article/opr/t114/e6447 (accessed January31, 2014).

Rothestien, Edward. "Piano: Works of Nordics." New York Times 1923-Current File (October 1981): C31.

Rosenberg, Hilding. “A Journey in Modern Swedish Music.” Music \& Letters 28, no. 3 (July 1947): 249-257.

Weinstock, John. "Wilhelm Stenhammar och hans tid. Vol. 1: Vol. 2: Vol. 3 by Bo Wallner." Scandinavian Studies (Winter 1993): 148-152.

\section{Dissertations}

Frost, Johan. "Swedish Piano Music by Stenhammar in the Shadow of Grieg." DMA diss., Rice University, 2001.

Shaomian, Armen. "The influence of composers Wilhelm Peterson-Berger and Wilhelm Stenhammar on Swedish National Romanticism." DMA diss., University of Miami, 2008. 
$\underline{\text { Scores }}$

Schumann, Robert. Sonata in G minor Opus 22 and Presto Passionato for the Piano. Edited by Harold Bauer. New York: G. Schirmer, 1946.

Stenhammar, Wilhelm. Sonata in G minor. Edited by Martin Sturfält. Sweden: Musikaliska Konstföreningen, 2008.

. Sonata in A-flat Op.12. Edited by Julius Hainauer. Copenhagen: Nordisk Musikforlag, 1900.

. Sonata in C Major, in C minor, and in A-flat Major (unpublished). Stockholm: Music Library of Sweden.

Appendix

Available recording in chronological order of the release date

\begin{tabular}{|l|l|l|}
\hline Performer and Release date & Title of recording & \\
\hline Lucia Negro (1997) & $\begin{array}{l}\text { Complete Stenhmmar Piano Works } \\
\text { Vol.2 and 3. }\end{array}$ & $\begin{array}{l}\text { All five sonatas, character } \\
\text { pieces. }\end{array}$ \\
\hline Niklas Sivelov (1998) & Wilhelm Stenhammar: Piano Works & $\begin{array}{l}\text { G minor piano sonata and } \\
\text { character pieces }\end{array}$ \\
\hline Kristina Svanberg (2000) & $\begin{array}{l}\text { Romanza: Scandinavian Piano } \\
\text { Music }\end{array}$ & $\begin{array}{l}\text { G minor piano sonata and } \\
\text { works by other } \\
\text { Scandinavian composers. }\end{array}$ \\
\hline Alexander Vaulin (2000) & $\begin{array}{l}\text { Scandinavian Romantic Piano } \\
\text { Music, Vol.2. }\end{array}$ & $\begin{array}{l}\text { G minor sonata and works } \\
\text { by other Scandinavian } \\
\text { composers }\end{array}$ \\
\hline Risto Kyro (2005) & Swedish Piano Music & $\begin{array}{l}\text { G minor sonata and works } \\
\text { by other Scandinavian } \\
\text { composers }\end{array}$ \\
\hline Martin Sturfält (2008) & Wilhelm Stenhammar: Piano Music & $\begin{array}{l}\text { G minor sonata, A-flat } \\
\text { Op.12 sonata, and character } \\
\text { pieces }\end{array}$ \\
\hline Cassandra Wyss (2012) & Wilhelm Stenhammar: Klavierwerke & $\begin{array}{l}\text { A-flat Op.12 sonata and } \\
\text { character pieces }\end{array}$ \\
\hline
\end{tabular}

